\title{
WESTPHALEN EN ÍNSULAS EXTRAÑAS EN EL CENTENARIO DE SU NACIMIENTO
}

\author{
Mario Pantoja Palomino
}

Emilio Adolfo Westphalen, uno de los grandes poetas del surrealismo peruano y latinoamericano (junto a César Moro, el de La tortuga ecuestre), de quien el año 2011 se cumplió el centenario de su nacimiento, publicó dos libros fundamentales en la década del treinta: Las insulas extrañas (1933) y Abolición de la muerte (1935); para luego reunir en un solo volumen toda su producción poética, bajo el título de Belleza de una espada clavada en la lengua (1986). Westphalen a partir de su acercamiento a César Moro (que formó parte del grupo de artistas liderado por André Breton), se convirtió en uno de los principales difusores de la propuesta surrealista en América Latina. En su gran mayoría, en Las insulas extrañas las composiciones son poemas de amor, pero se trata de un amor que ha terminado $y$ ya pertenece al pasado y los poemas van dirigidos a una amada ausente. "El gran tema, la gran pasión de la poesía de Westphalen -como dice Javier Sologuren- es el amor". Al mismo tiempo afirma el autor de Las uvas del racimo "que los poemas westphalianos son en definitiva un haz de vislumbres. Un haz, nada menos. Pero dotado de una viva unidad y crecido conforme a un ponderado diseño estructural. Llevan razón por consiguiente quienes destacan el control de una inteligencia configuradora en la escritura de sus poemas". Los textos, tanto del primer libro como del segundo, han de verse como una lucha contra el tiempo y la muerte, como una búsqueda del tiempo perdido, en la cual el poeta se esfuerza por recuperar la felicidad del amor perdido mediante la memoria y la imaginación poética. Y como señala Ricardo González Vigil, "Westphalen asimiló mucho del Surrealismo (la triada poesíarevolución-amor, el culto a las asociaciones libres y soterradas), llegando a componer textos calificables de surrealistas $(.$.$) , pero en los dos poemarios$ citados arriba somete la lección surrealista a un registro distinto, más arquitectónico, producto de una escritura vigilante y escrupulosa, diversa del mero 'automatismo psíquico'. En el plano vital, de otro lado, optar por una insularidad y una discreción poco compaginables con la 'vida escandalosa' de los surrealistas cabales".

En sus dos libros, Westphalen "ha hablado con esa voz, que es la suya y es la de todos y es la de nadie: la voz del otro que es cada uno de nosotros. Al mismo tiempo, ha oído el silencio que precede, acompaña y sigue a esa voz. Ese silencio alternativamente nos atrae y nos aterra; por eso, muchos poetas, sin excluir a los más grandes, sienten la tentación de cubrirlo con las palabras de la elocuencia o de la retórica (...). El silencio de Westphalen es el complemento de su voz. Cada uno de sus poemas es como una torre rodeada de noche: su chorro pétreo, obscuro y luminoso, se levanta sobre una masa de silencio completo" (Paz 1979: 165). En Abolición de la muerte -que es el libro más dificil para descubrir la intencionalidad del autor- la memoria suele salir triunfante, aboliendo el tiempo y la muerte al rescatar de la niebla del pasado la figura de la amada y la felicidad asociada con ella.

En toda la obra poética de Westphalen -por cierto- el gran tema es el amor del pasado. Es probable que la intensidad visionaria de su erotismo no tenga parangón en toda nuestra poesía del siglo XX. Si en Las ínsulas extrañas prevalece la zozobra que tiñe su expresión con las lividas tintas de la pesadilla y en todo momento nos permite asistir a sus oscuros combates; en Abolición de la muerte se manifiesta, así desde su título mismo, una voluntad 
y una consigna: destruir, por el amor, a la muerte. El poeta ha dicho: que él estuvo "en soledad de amor herido" y de esa herida brotó íntegra su poesía.

Con Las insulas extrañas y Abolición de la muerte hace una de sus primeras apariciones el Surrealismo en América Latina. Como se sabe, Westphalen fue el amigo y el compañero de César Moro y sus nombres están unidos en la historia del surrealismo peruano y latinoamericano. Pero "el surrealismo de Westphalen, como lo indican los títulos mismos de sus libros, estaba enlazado a otras preocupaciones espirituales que lo acercan a una gran tradición de nuestra civilización: la mística
La niebla otra vez otra barca / Los remos el amor no se mueve / Sabe cerrar los ojos dormir el aire no los ojos / La ola alcanza los ojos / Duermen junto al río la cabellera / Sin peligro de naufragio en los ojos / Calma tardanza el cielo / O los ojos / Fuego fuego fuego fuego / En el cielo cielo fuego cielo / Cómo rueda el silencio / Por sobre el cielo el fuego el amor el silencio / Qué suplicio baña la frente el silencio / Detrás de la ausencia mirabas sin fuego / Es ausencia noche / Pero los ojos el fuego / Caricia estío los ojos la boca / El fuego nace en los ojos / El amor nace en los ojos el cielo el fuego / El fuego el amor el silencio".

En este texto, como en los demás de Las insulas extrañas, Westphalen rehúye al uso de formas métricas tradicionales y, por el contrario, actualiza una polimetría conforme a la estética vanguardista (empleando versos tetrasílabos, octosílabos, eneasílabos, decasílabos, hasta versos de dieciséis sílabas). Asimismo se puede evidenciar que existen por lo menos quince unidades rítmicas de acentuación ternaria, vale decir, aquellos cuyo ritmo interno se manifiesta en la acentuación vigorosa de tres sílabas: "Despues la niebla la noche (...) / Me miran los ojos el cielo (...) / Cómo rueda el silencio (...) / El fuego nace en los ojos".

El ritmo ternario en este texto implica un abandono de la métrica tradicional. El poeta huye de la rima o del alejandrino modernista $y$, por ende, se apoya en otros recursos rítmicos, uno de los cuales es reforzar la musicalidad de los versos con la acentuación poética de determinados ejes silábicos. En la poesía de Westphalen cada verso conserva su autonomía respecto de los otros. Evidentemente hay excepciones, pero el fragmentarismo verbal es muy frecuente y nos recuerda el tipo de funcionamiento de los discursos oníricos, es decir, el texto poético fragmentado opera con una determinada modalidad discursiva que se asemeja mucho a la que prima en el lenguaje de los sueños. De modo consecuente, Pierre Reverdy expresa sobre el valor del sueño lo siguiente: "No creo que el sueño sea estrictamente lo contrario del pensamiento. Lo que sé de él me inclina a pensar que, después de todo, no es más que una forma más libre y más abandonada de él. El sueño y el pensamiento son lados distintos de una misma cosa, el revés y el derecho, siendo el sueño el lado en que la trama es más rica y menos estricta, y el pensamiento aquel en que la trama es más sobria pero más tupida" (Nadeau 1972: 82). El mar / Cuántas barcas / Las olas dicen amor / 
Es sabido que con los esfuerzos de André Breton, Louis Aragon y Paul Eluard, el surrealismo llegó a afianzarse sólidamente en el período de entreguerras, es decir entre la Primera y la Segunda Guerra Mundial. Esta nueva escuela vanguardista, aparecida en octubre de 1924 con la publicación del Primer Manifiesto Surrealista por André Breton -luego de romper todo vínculo con Tristan Tzara y el Dadaísmo-, fue un movimiento de exterior ambiguo, con un tinte mitad romántico -por sus apelaciones al sueño- y mitad paracientífico, por su utilización de Freud, más cierto afán sistemático. El autor de Nadja y Los vasos comunicantes, desde las primeras páginas de su primer Manifiesto, sustentaba al surrealismo como un antirrealismo, antinaturalismo, negación y aun reprobación absoluta de lo real como materia y base del arte. Breton ha llegado a decir que "Heráclito es surrealista en la dialéctica, Llull en la definición, Baudelaire en la moral, Rimbaud en la práctica de la vida". "La poética surrealista propone la búsqueda de una superrealidad capaz de ser alcanzada cuando el hombre aprenda a mirar el mundo con otros ojos. De hecho se trata de una nueva versión de una poética que se remonta hasta los románticos y que entra en auge en la época simbolista, una poética que concibe la poesía como un vehículo para captar el mundo ideal que yace detrás de las apariencias del mundo material" (Higgins 1984: 16).

En las dos publicaciones de los años 30 -Las insulas extrañas y Abolición de la muerte-, las composiciones son poemas de amor, que tratan de un romance que ha terminado y ya pertenece al pasado y los poemas van dirigidos a una amada ausente. Pues así en "No es válida esta sombra" lamenta el vacío en el cual se ha convertido la vida del poeta con la pérdida de la amada: "Se despega una nada tras otra / Crece una nada sobre nada / Y había ríos que se iban en vueltas y derechas / Y había árboles con algo más que ramas y algunas hojas / El sol no hacía en vano su camino..." En tanto en "Andando el tiempo", el primer poema de Las insulas extrañas, tan sorprendente por su esencia surrealista para quienes habíamos leído a Eguren simbolista y a Vallejo vanguardista a partir de Trilce, sitúa la obra de Westphalen en el contexto de un mundo regido por la inexorable marcha del tiempo, y "Hojas secas para tapar ...", otro de los poemas de este mismo libro, está construido alrededor de la imagen del otoño, símbolo del inevitable desgaste de la vida por la muerte, un proceso que hace irrisoria toda actividad humana por más que los hombres cierren los ojos ante él, y dice el poeta: "Tal vez nunca se ha dado más el otoño a la angustia del hombre".

"La poesía de Westphalen -a decir de Higginsha de verse en ese contexto, como una lucha contra el tiempo y la muerte, como una búsqueda del tiempo perdido en la cual el poeta se esfuerza por recuperar la felicidad del amor perdido mediante la memoria y la imaginación poética".

Entre tanto un texto revelador al interior de Las insulas extrañas es: "Un árbol se eleva hasta el extremo de los cielos...", que evoca, como símbolo de la existencia terrestre que se rebela contra sus límites y se esfuerza por superarlos, la imagen de un árbol que se levanta hasta tocar el techo del cielo y golpea contra él en su afán de ir más allá: "Un árbol se eleva hasta el extremo de los cielos que lo cobijan / Golpea con dispersa voz / El árbol contra el cielo contra el árbol / Es la lluvia encerrada en tan poco de espacio /... / Golpea con las ramas la voz el dolor / No hagas tal fuerza por que te oigan / Yo te cedo mis dedos mis ramas / Así podrás raspar arañar gritar y no solamente llorar / Golpear con la voz ...".

En este poema, "el árbol también se golpea a sí mismo porque su rebelión contra el cielo y el límite que este representa es a la vez una rebelión contra su condición de árbol arraigado en el suelo. El ruido insistente de sus golpes hace recordar el de la lluvia en un espacio restringido, y este paralelo sirve para destacar que está clamando por salir de sus confines terrestres. Los golpes dan también contra el alma del poeta, despertando su solidaridad ya que él comparte los mismos anhelos y por eso ofrece prestar ayuda al árbol en su empresa" (Higgins 1984: 17). En los versos siguientes de "Un árbol se eleva ...": "Agua / Y navegan los rojos galeones por la gota de agua / En la gota de agua zozobran / Acaso golpea el tiempo / Otra gota / Agua / La garganta de fuego agua agua / Matado por el fuego / La llamarada gigantesca / Maravilloso final / Muerto sin agua en el fuego / La mano arañaba el fuego ...".

Los galeones que zozobran en una gota de agua son otro símbolo de un deseo demasiado infinito para ser satisfecho por el mundo corriente. "Este deseo el poeta lo experimenta en forma de una sed de fuego que le quema la garganta y amenaza con consumirlo, y con insistencia reclama agua para apaciguarla. Pero, como el deseo sexual, este fuego que lo devora por dentro también resulta 
placentero, y el proceso delirante mediante el cual su sed crece y crece hasta convertirse en fuego absoluto se parece al crescendo que lleva al orgasmo. De esta forma el fuego de su sed se transforma en el fuego del arrebato místico" (Higgins 1984: 18).

De otro lado, Carlos Garayar dice: "La poesía de Westphalen impacta de un modo distinto del usual. Para acceder a ella el lector necesita tener una actitud igualmente distinta, más aún si se trata de un lector que busca luego comunicar su experiencia. La poesía de Westphalen no se deja asir desde afuera; más bien, invita al lector a sumergirse en su caudal, abandonando las reservas conscientes que lo mantienen en esta margen, para sólo después experimentarla en toda su intensidad y hermosura. Fabricadas de esa materia universal y sutil con que el hombre teje sus sueños, las imágenes que cuelgan de sus versos como de hilos de araña, amenazan romperse, volverse nada al menor intento de extraerlas para el examen" (Fernández Cozman, 1990: 12).

En cambio, en Abolición de la muerte - $\mathrm{el}$ libro más dificil de entender plenamente que Las insulas extrañas, como ya dije- la memoria suele salir triunfante, aboliendo el tiempo y la muerte al rescatar de la niebla del pasado la figura de la amada y la felicidad asociada con ella. En algunos casos, como en "Marismas llenas de corales...", "una compleja interacción de tiempos verbales destaca -a la manera borgiana- la lucha entre la memoria y el tiempo, pero en otros las barreras temporales quedan borradas y la imagen de la amada surge del pasado para revivificar al poeta en un momento de calidad eterna": "Has venido pesada como el rocío sobre las flores del jarrón /

\section{BibLIOGRAFía}

\section{AZAR, Vicente}

1934. "Violencia de Westphalen". En: Social No 73, año 4. Lima, 5 de marzo de 1934.

\section{BRETON, André}

1965. Los Manifiestos del Surrealismo. Traducción, prólogo y notas de Aldo Pelligrini. Buenos Aires, Ediciones Nueva Visión.

\section{CUETO, Alonso}

1980. "Westphalen: el laberinto del silencio". En: Hueso húmero $\mathrm{N}^{\circ}$ 7. Lima, octubre - 1980 diciembre de 1980.

\section{FERNÁNDEZ COZMAN, Camilo}

1990. Las Insulas Extrañas de Emilio Adolfo Westphalen. Lima, Naylamp Editores.

\section{GONZÁLEZ VIGIL, Ricardo}

1977. "Westphalen o el esplendor de la imaginación lírica". En: Creación \& Crítica No 20. Lima, agosto 1977.
Has venido para borrar tu venida / Estandarte de siglos clavado en nuestro pecho".

En esta compleja obra, Abotición de la muerte: "Para los muertos no hay muerte ya. Pero entre vida y muerte hay un instante que las anula o que las funde: ese instante se llama sueño, se llama contemplación, se llama amor (...). El tiempo, ha dicho Westphalen, es una escalera que baja porque nadie la sube. $\mathrm{Su}$ poesía es una invitación a subirla para, ya arriba, ver lo que pasa del otro lado" (Paz 1979: 167).

En los poemas de Abolición de la muerte, los esfuerzos de Westphalen por captar la imagen esquiva de la amada ausente están referidos de una manera que hace recordar "la búsqueda de unión con la divinidad de los poetas místicos": San Juan de la Cruz y Santa Teresa de Jesús, de quienes recibió claras influencias. Vicente Azar -poeta de espiritu surrealista de los años treinta- escribe un breve ensayo no exento de interés donde califica la obra de Westphalen como "poesía del silencio". Azar se detiene en la atmósfera poética westphaliana y dice: "Tiécnicamente la modalidad, surrealista en esta pura poesía de Westphalen ejerce de vivificación y de toque o mirada complacida sobre la total estructura lírica intangible". El autor del ensayo "Violencia de Westphalen" resalta la forma como el poeta surrealista "busca violentar el universo verbal". Pero finalmente dice con precisión parnasiana: "Ahí reside la grandeza de Westphalen quien es un alto poeta del Perú". Pues así, con Vicente Azar coincidimos plenamente -en la imaginación crítica de ponerle en un alto sitial a Westphalen-, sin dejar de pensar en Chocano, en Vallejo y en Romualdo, tres de las otras grandes montañas de la poesía peruana y latinoamericana.

1999. Poesía Peruana Siglo XX. Del Modernismo a los años 50. Selección, prólogo y notas de Ricardo González Vigil. Lima, Editado por el Departamento de Relaciones Públicas de Petroperú, S.A. Tomo I.

\section{HIGGINS, James}

1984. "Westphalen, Moro y la poética surrealista". En: Cielo Abierto $\mathrm{N}^{\circ}$ 29. Lima, 1984.

\section{LAUER, Mirko y Abelardo Oquendo}

1970. Vuelta a la otra margen. Selección de Mirko Lauer y Abelardo Oquendo. Lima, Casa de la Cultura del Perú.

\section{NADEAU, Maurice}

1972. Historia del Surrealismo. Traducción castellana de JuanRamón Capella. Barcelona, Ediciones Ariel.

\section{ORTEGA, Julio}

1977. "Una nota sobre Westphalen". En: Creación \& Crítica No 20. Lima, agosto 1977. 
PAZ, Octavio

1979. In / Mediaciones. Barcelona, Editorial Seix Barral, S.A.

\section{SOLOGUREN, Javier}

1980. "Perspectivas sobre lapoesía de Emilio Adollo Wesuphalen".

En: La Gaceta del Fondo de Cultura Económica $N^{\circ} 110$. México, Nueva Epoca, febrero de 1980.

\section{TORRE, Guillermo de}

1974. Historia de las Literaturas de Vanguardia. Madrid, Ediciones Guardarrama, S.A. 3 tomos.

\section{WESTPHALEN, Emilio Adolfo}

1986. Belleza de una espada clarada en la lengua. Poemas 1930 1986. Lima, Ediciones Rikchay. 


\section{Poemas de Westrhalen}

(Selección de Mario Pantoja Palomino)

UNA CABEZA HUMANA viene lenta desde el olvido

Tenso se detiene el aire

Vienen lentas sus miradas

Un lirio trae la noche a cuestas

Cómo pesa el olvido

La noche es extensa

El lirio una cabeza humana que sabe el amor

Más débil no es sino la sombra

Los ojos no niegan

El lirio es alto de antigua angustia

Sonrisa de antigua angustia

Con dispar siniestro con impar

Tus labios saben dibujar una estrella sin equívoco

He vuelto de esa atareada estancia y de una temerosa

Tú no tienes temor

Eres alta de varias angustias

Casi llega al amor tu brazo extendido

Yo tengo una guitarra con sueño de varios siglos

Dolor de manos

Notas truncas que se callaban podían dar al mundo lo que (faltaba

Mi mano se alza más bajo

Coge la última estrella de tu paso y tu silencio

Nada igualaba tu presencia con un silencio olvidado en tu (cabellera

Si hablabas nacía otro silencio

Si callabas el cielo contestaba

Me he hecho recuerdo de hombre para oírte

Recuerdo de muchos hombres

Presencia de fuego para oírte

Detenida la carrera

Atravesados los cuerpos y disminuidos

Pero estás en la gloria de la eterna noche

La lluvia crecía hasta tus labios

No me dices en cuál cielo tienes tu morada

En cuál olvido tu cabeza humana

En cuál amor mi amor de varios siglos

Cuento la noche

Esta vez tus labios se iban con la música

Otra vez la música olvidó los labios

Oye si me esperaras detrás de este tiempo

Cuando no huyen los lirios

Ni pesa el cuerpo de una muchacha sobre el relente de las (horas 
Ya me duele tu fatiga de no querer volver

Tú sabías que te iba a ocultar el silencio el temor el tiempo (tu cuerpo

Que te iba ocultar tu cuerpo

Ya no encuentro tu recuerdo

Otra noche sube por tu silencio

Nada para los ojos

Nada para las manos

Nada para el dolor

Nada para el amor

Por qué te había de ocultar el silencio

Por qué te habían de perder mis manos y mis ojos

Por qué te habían de perder mi amor y mi amor

Otra noche baja por tu silencio

(De Las insulas extrañas)

$$
* * *
$$

VINISTE a posarte sobre una hoja de mi cuerpo

Gota dulce y pesada como el sol sobre nuestras vidas

Trajiste olor de madera y ternura de tallo inclinándose

$\mathrm{Y}$ alto velamen de mar recogiéndose en tu mirada

Trajiste paso leve de alba al irse

$\mathrm{Y}$ escandido incienso de arboledas tremoladas en tus

$$
\text { (manos }
$$

Bajaste de brisa en brisa como una ola asciende los días

$Y$ al fin eras el quedado manantial rodando las flores

$\mathrm{O}$ las playas encaminándose a una querella sin motivo

Por decir si tu mano estuvo armoniosa en el tiempo

O si tu corazón era fruta de árbol o de ternura

$\mathrm{O}$ el estruendo callado del surtidor

O la voz baja de la dicha negándose y afirmándose

En cada diástole y sístole de permanencia y negación

Viniste a posarte sobre mi copa

Roja estrella y gorgorito completo

Viniste a posarte como la noche llama a sus creaturas

O como el brazo termina su círculo y abarca el horario

(completo

O como la tempestad retira los velos de su frente

Para mirar el mundo y no equivocar sus remos

Al levantar los muros y cerrar las cuevas

Has venido y no se me alcanza qué justeza equivocas

Para estarte sin levedad de huida y gravitación de planeta

Orlado de madreselvas en la astrología infantil

Para estarte como la rosa hundida en los mares

$\mathrm{O}$ el barco anclado en nuestra conciencia

Para estarte sin dar el alto a los minutos subiendo las

(jarcias 
Y cayéndose siempre antes de tocar el timbre que llama

(a la muerte

Para estarte sitiada entre son de harpa y río de escaramuza

Entre serpiente de aura y romero de edades

Entre lengua de solsticio y labios de tardada morosidad (acariciando

Has venido como la muerte ha de llegar a nuestros labios

Con la gozosa transparencia de los días sin fanal

De los conciertos de hojas de otoño y aves de verano

Con el contento de decir he llegado

Que se ve en la primavera al poner sus primeras manos

(sobre las cosas

Y anudar la cabellera de las ciudades

Y dar vía libre a las aguas y canto libre a las bocas

De la muchacha al levantarse y del campo al recogerse

Has venido pesada como el rocío sobre las flores del jarrón

Has venido para borrar tu venida

Estandarte de siglos clavado en nuestro pecho

Has venido nariz de mármol

Has venido ojos de diamante

Has venido labios de oro

$$
* * *
$$

TE HE SEGUIDO como nos persiguen los días

Con la seguridad de irlos dejando en el camino

De algún día repartir sus ramas

Por una mañana soleada de poros abiertos

Columpiándose de cuerpo a cuerpo

Te he seguido como a veces perdemos los pies

Para que una nueva aurora encienda nuestros labios

$Y$ ya nada puede negarse

$Y$ ya todo sea un mundo pequeño rodando las escalinatas

Y ya todo sea una flor doblándose sobre la sangre

Y los remos hundiéndose más en las auras

Para detener el día y no dejarle pasar

Te he seguido como se olvidan los años

Cuando la orilla cambia de parecer a cada golpe de viento

Y el mar sube más alto que el horizonte

Para no dejarme pasar

Te he seguido escondiéndome tras los bosques y las

$$
\text { (ciudades }
$$

Llevando el corazón secreto y el talismán seguro

Marchando sobre cada noche con renacidas ramas

Ofreciéndome a cada ráfaga como la flor se tiende en la onda

$\mathrm{O}$ las cabelleras ablandan sus mareas

Perdiendo mis pestañas en el sigilo de las alboradas

Al levantarse los vientos y doblegar los árboles y las torres

Cayéndome de rumor en rumor 
Como el día soporta nuestros pasos

Para después levantarme con el báculo del pastor

Y seguir las riadas que separan siempre

La vid que ya va a caer sobre nuestros hombros

$Y$ la llevan cual un junco arrastrado por la corriente

Te he seguido por una sucesión de ocasos

Puestos en el muestrario de las tiendas

Te he seguido ablandándome de muerte

Para que no oyeras mis pasos

Te he seguido borrándome la mirada

Y callándome como el río al acercarse al abrazo

O la luna poniendo sus pies donde no hay respuesta

$Y$ me he callado como si las palabras no me fueran a llenar

(la vida

Y ya no me quedara más que ofrecerte

Me he callado porque el silencio pone más cerca los labios

Porque sólo el silencio sabe detener a la muerte en los (umbrales

Porque sólo el silencio sabe darse a la muerte sin reservas

Y así te sigo porque sé que más allá no has de pasar

$Y$ en la esfera enrarecida caen los cuerpos por igual

Porque en mí la misma fe has de encontrar

Que hace a la noche seguir sin descanso al día

Ya que alguna vez le ha de coger y no le dejará de los dientes

Ya que alguna vez le ha de estrechar

Como la muerte estrecha a la vida

Te sigo como los fantasmas dejan de serlo

Con el descanso de verte torre de arena

Sensible al menor soplo u oscilación de los planetas

Pero siempre de pie y nunca más lejos

Que al otro lado de la mano

$* * *$

HE DEJADO descansar tristemente mi cabeza

En esta sombra que cae del ruido de tus pasos

Vuelta a la otra margen

Grandiosa como la noche para negarte

He dejado mis albas y los árboles arraigados en mi garganta

He dejado hasta la estrella que corría entre mis huesos

He abandonado mi cuerpo

Como el naufragio abandona las barcas

O como la memoria al bajar las mareas

Algunos ojos extraños sobre las playas

He abandonado mi cuerpo

Como un guante para dejar la mano libre

Si hay que estrechar la gozosa pulpa de una estrella

No me oyes más leve que las hojas

Porque me he librado de todas las ramas 
Y ni el aire me encadena

Ni las aguas pueden contra mi sino

No me oyes venir más fuerte que la noche

Y las puertas que no resisten a mi soplo

$\mathrm{Y}$ las ciudades que callan para que no las aperciba

$Y$ el bosque que se abre como una mañana

Que quiere estrechar el mundo entre sus brazos

Bclla ave que has de caer en el paraíso

Ya los telones han caído sobre tu huída

Ya mis brazos han cerrado las murallas

Y las ramas inclinado para impedirte el paso

Corza frágil teme la tierra

Teme el ruido de tus pasos sobre mi pecho

Ya los cercos están enlazados

Ya tu frente ha de caer bajo el peso de mi ansia

Ya tus ojos han de cerrarse sobre los míos

$Y$ t tu dulzura brotarte como cuernos nuevos

$\mathrm{Y}$ tu bondad extenderse como la sombra que me rodea

Mi cabeza he dejado rodar

Mi corazón he dejado caer

Ya nada me queda para estar más seguro de alcanzarte

Porque llevas prisa y tiemblas como la noche

La otra margen acaso no he de alcanzar

Ya que no tengo manos que se cojan

De lo que está acordado para el perecimiento

$\mathrm{Ni}$ pies que pesen sobre tanto olvido

De huesos muertos y flores muertas

La otra margen acaso no he de alcanzar

Si ya hemos leído la última hoja

Y la música ha empezado a trenzar la luz en que has de (caer

Y los ríos te cierran el camino

$\mathrm{Y}$. las flores te llaman con mi voz

Rosa grande ya es hora de detenerte

El estío suena como un deshielo por los corazones

Y las alboradas tiemblan como los árboles al despertarte

Las salidas están guardadas

Rosa grande ¿no has de caer?

(De Abolición de la muerte) 


\section{EUlOGio NishiYAMA: Fotógrafo DEL CUSCO}

Nada más fidedigno que el lenguaje fotográfico en su intención de testimoniar la vida y los eventos humanos. Esta certeza se evidencia más cuando apreciamos el arte de Eulogio Nishiyama Gonzales (Cusco, 1920-1996), fotógrafo de ascendencia japonesa y testigo privilegiado de una época remecida por notables acontecimientos. Sin el registro de su cámara, quizás quedaría incompleta la narrativa histórica del Cusco correspondiente al siglo XX, tal vez sumergidos algunos sucesos que determinaron los cambios sociales y la decidida incursión en la modernidad. Gracias a este artista, resulta más amplio el panorama que podemos visualizar de nuestro pasado reciente, especialmente de su rica diversidad social y cultural.

Será que para el lente de Nishiyama nada de lo humano le era ajeno, según el decir del inspirado comediógrafo latino. Todo cuanto de destacable ocurría en la ciudad y la región, él lo registraba con vocación de perennidad, acudiendo con espíritu abierto, bien sea al acontecimiento político trascendente como la llegada a Cusco de Eva Duarte de Perón, al suceso familiar consistente en una humilde boda de campesinos, a la concentración de jinetes en la plaza de Santo Tomás, o a la manifestación eucarística en la plaza de armas. En suma, dotado de visión coreográfica y sensibilidad de artista plástico, el fotógrafo estaba allí donde latía el fervor de la multitud, impulsado por su voluntad de cronista de la historia cotidiana y también documentalista de eventos de más estricta memoria, atributos que honrosamente lo acercan a la prosapia estética de Chambi y de Figueroa Aznar.

Artista de doble pericia instrumental, Eulogio Nishiyama además incursionó en la cinematografia, llegando a ser el pionero del documental etnográfico en nuestro medio. Aquí filmó, desde la década de 1940, una serie de eventos de la cultura tradicional cusqueña (tanto rural como urbana), quizás bajo el influjo del discurso indigenista en boga, pero esencialmente motivado por sus arraigadas convicciones sociales. Son singulares sus documentales sobre la festividad de Quyllurit'i, el rito de Qhiswachaka, la tauromaquia chumbivilcana, el carnaval citadino de Cusco, y el concurso de belleza indígena, entre otros. En 1956 fue co-fundador del Cine Club Cusco, el cual, cinco años después, concretaría la primera película en lengua quechua: Kukuli, cuyo éxito hizo hablar al historiador francés George Sadoul sobre la existencia de la Escuela de Cine de Cusco.

Por todo ello, la Revista Universitaria presenta aquí una parte interesante del legado fotográfico de Eulogio Nishiyama y, al difundirla, cumple con revalorarlo como uno de nuestros más renombrados exponentes de las artes visuales. El recuperó las imágenes de un ayer cercano que todavía proyecta sus luces sobre la agenda social de este inicio de milenio. Su vasto testimonio gráfico bien puede ayudarnos a entender las claves interactivas que articulan el pasado con el presente, en perspectiva a diseñar las bases del futuro. (ERP) 


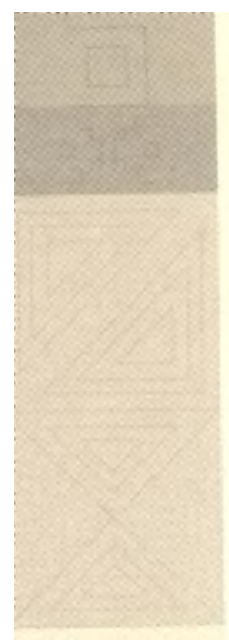

REVISTA UNIVERsTrARIA I4l

314

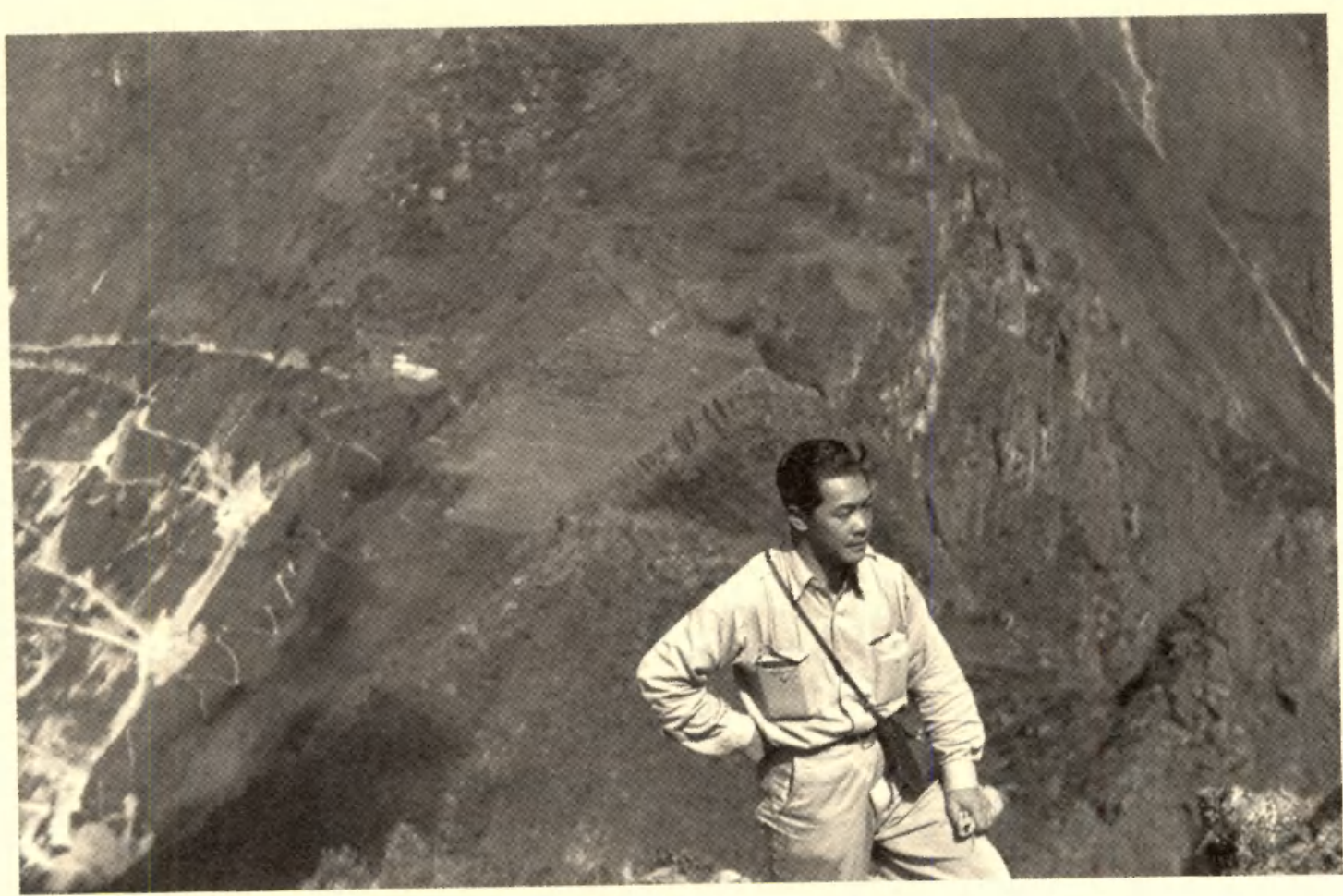

V Autossetrato.

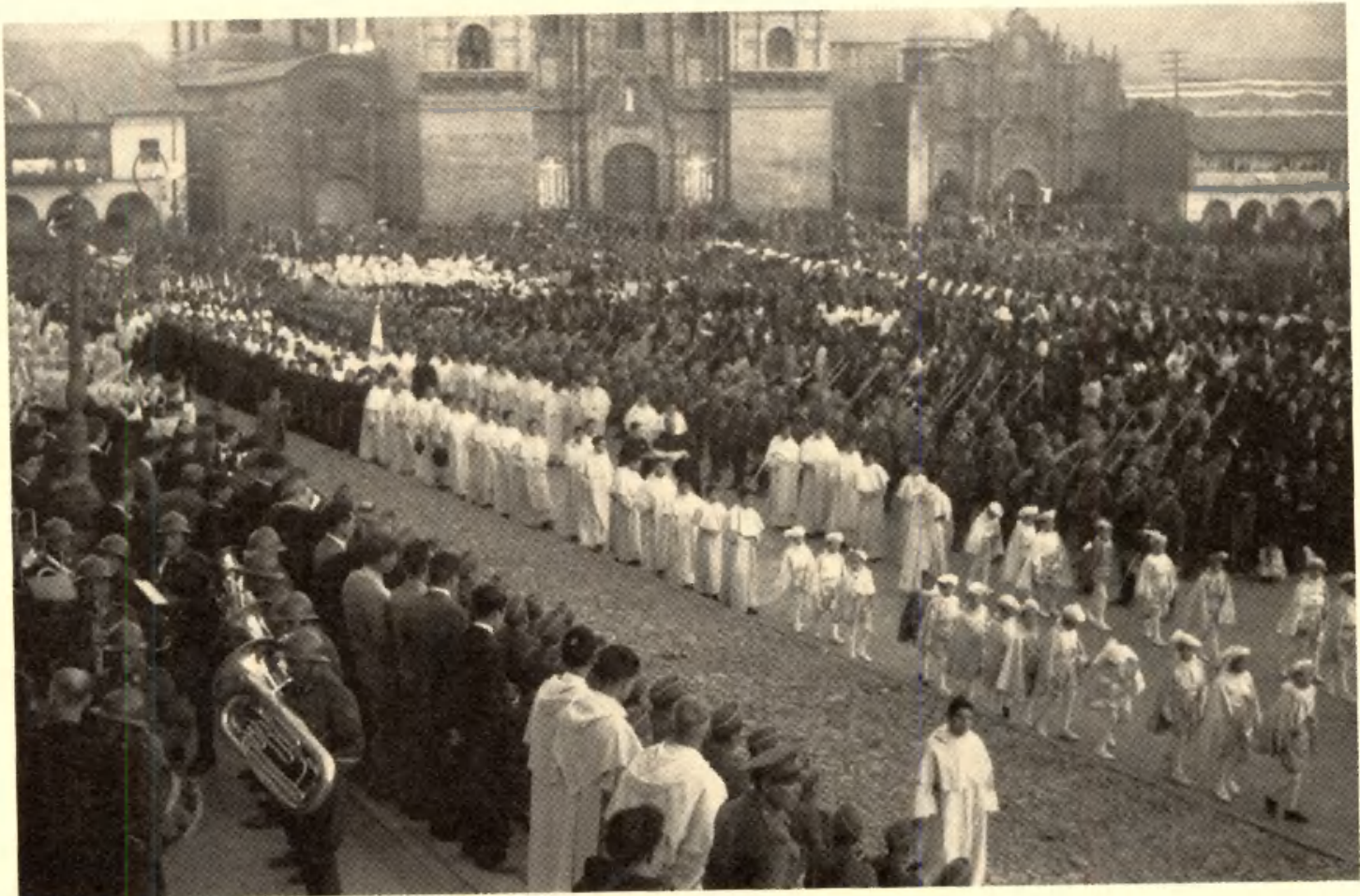

- Congreso Eutcaristico. 


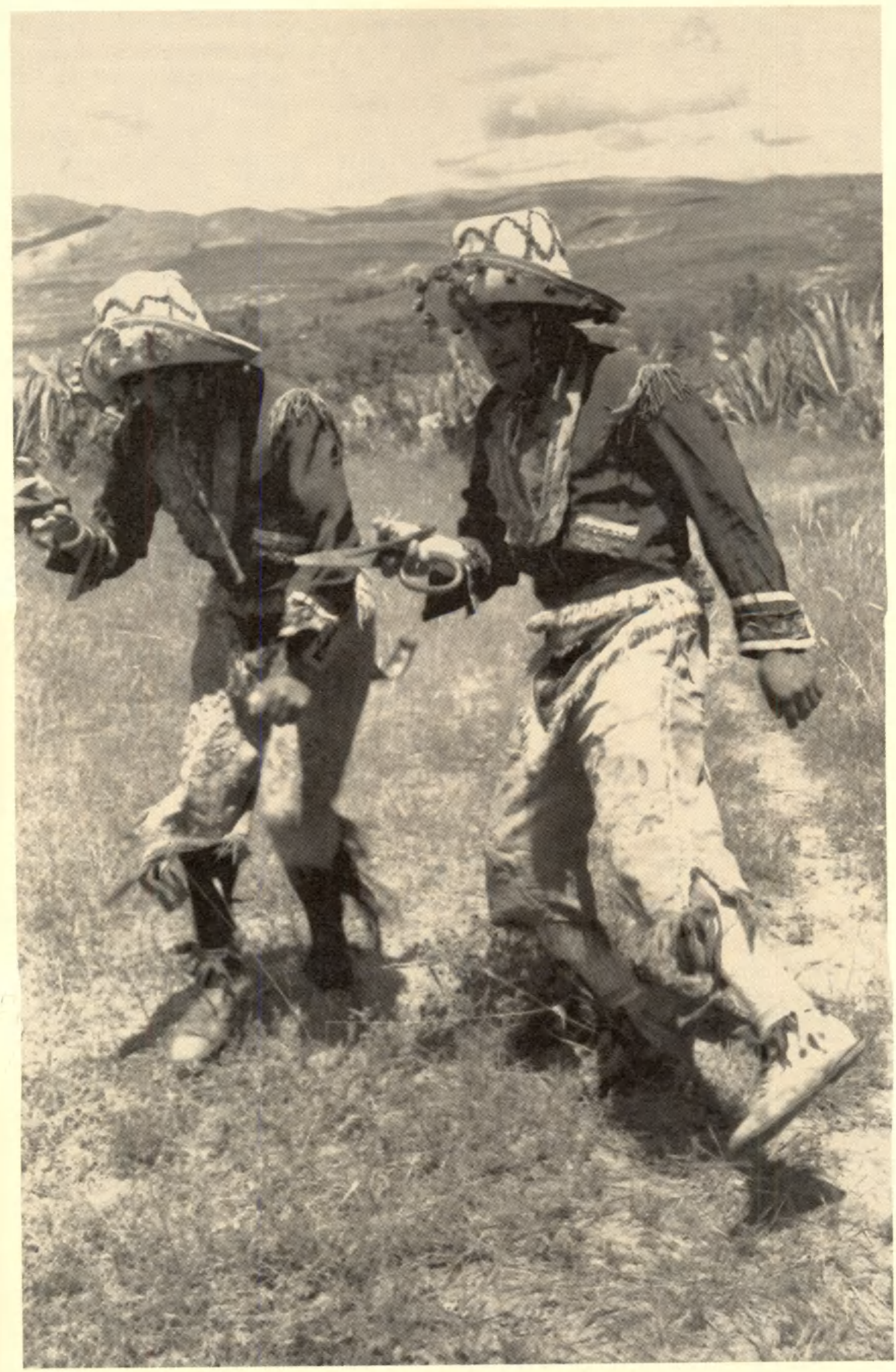




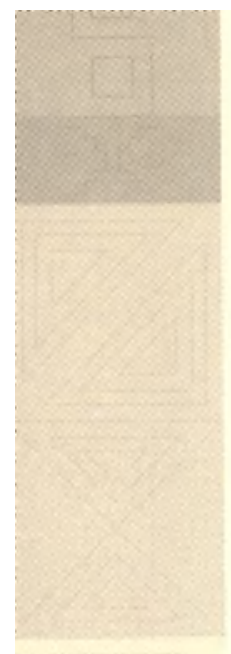

316

RENTSTA UNIVERSTTARIA 141

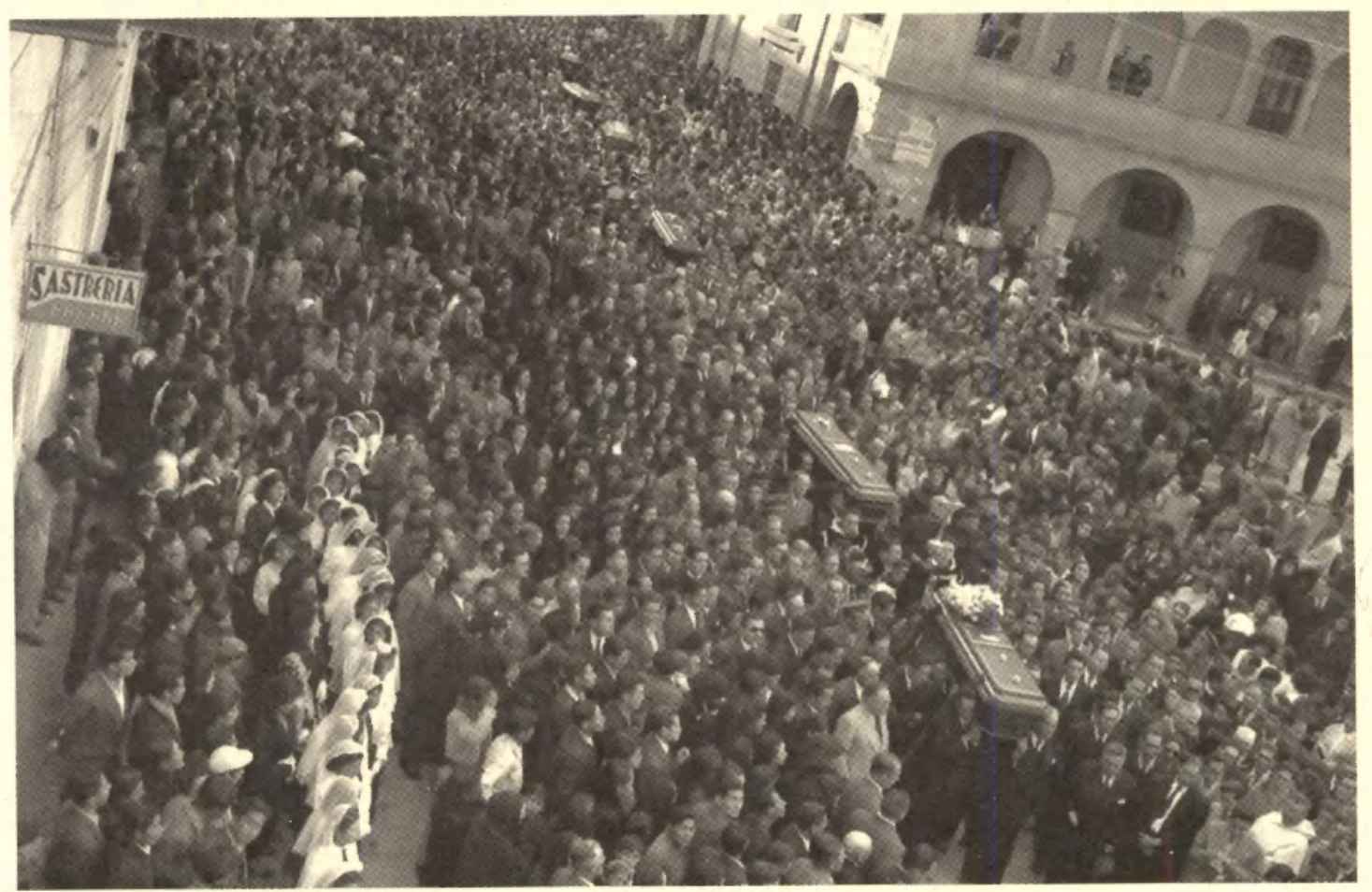

- Entierro de victimas de un accidente de aziación.

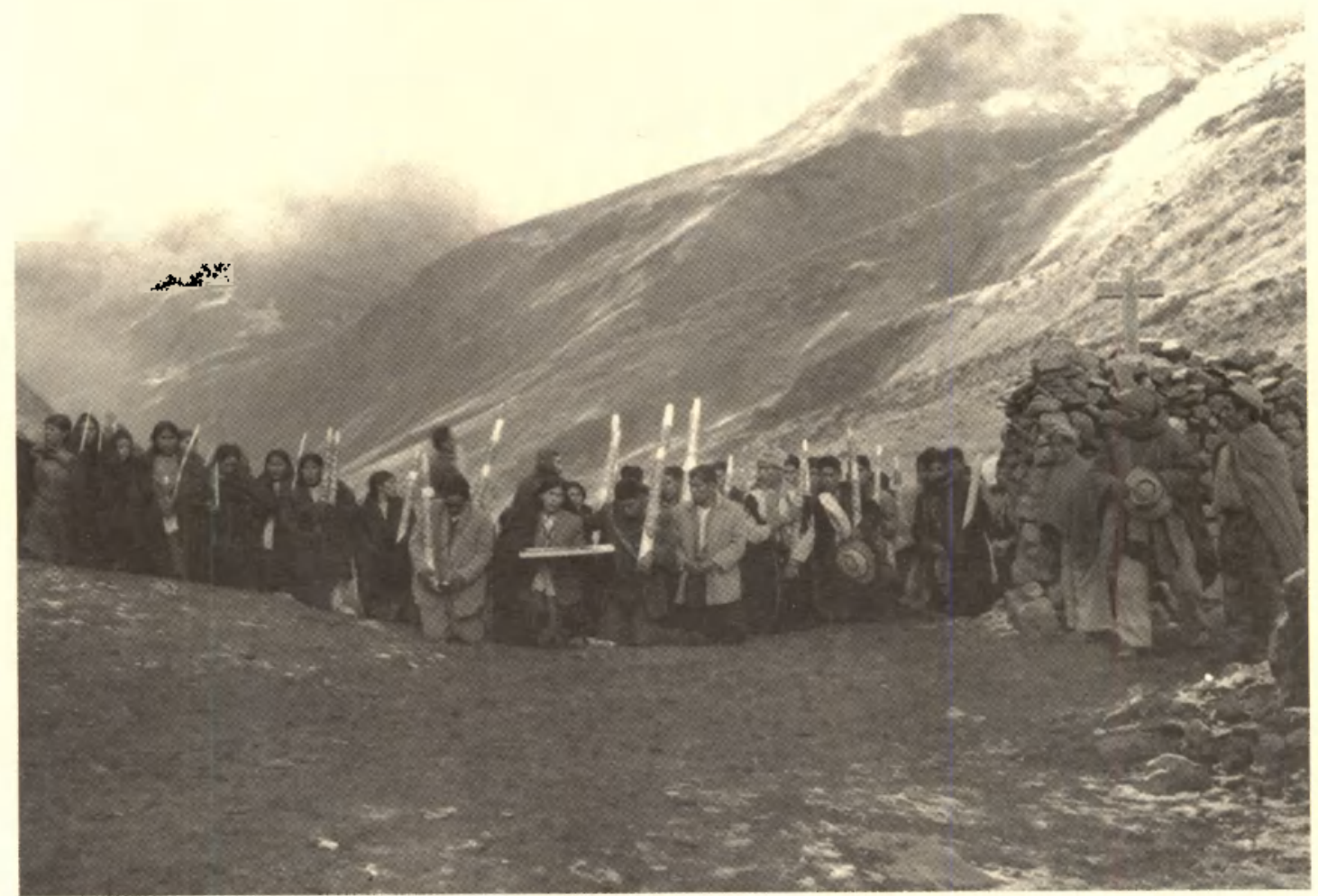

- Escena de Qutylut Riti. 
100 AÑOS

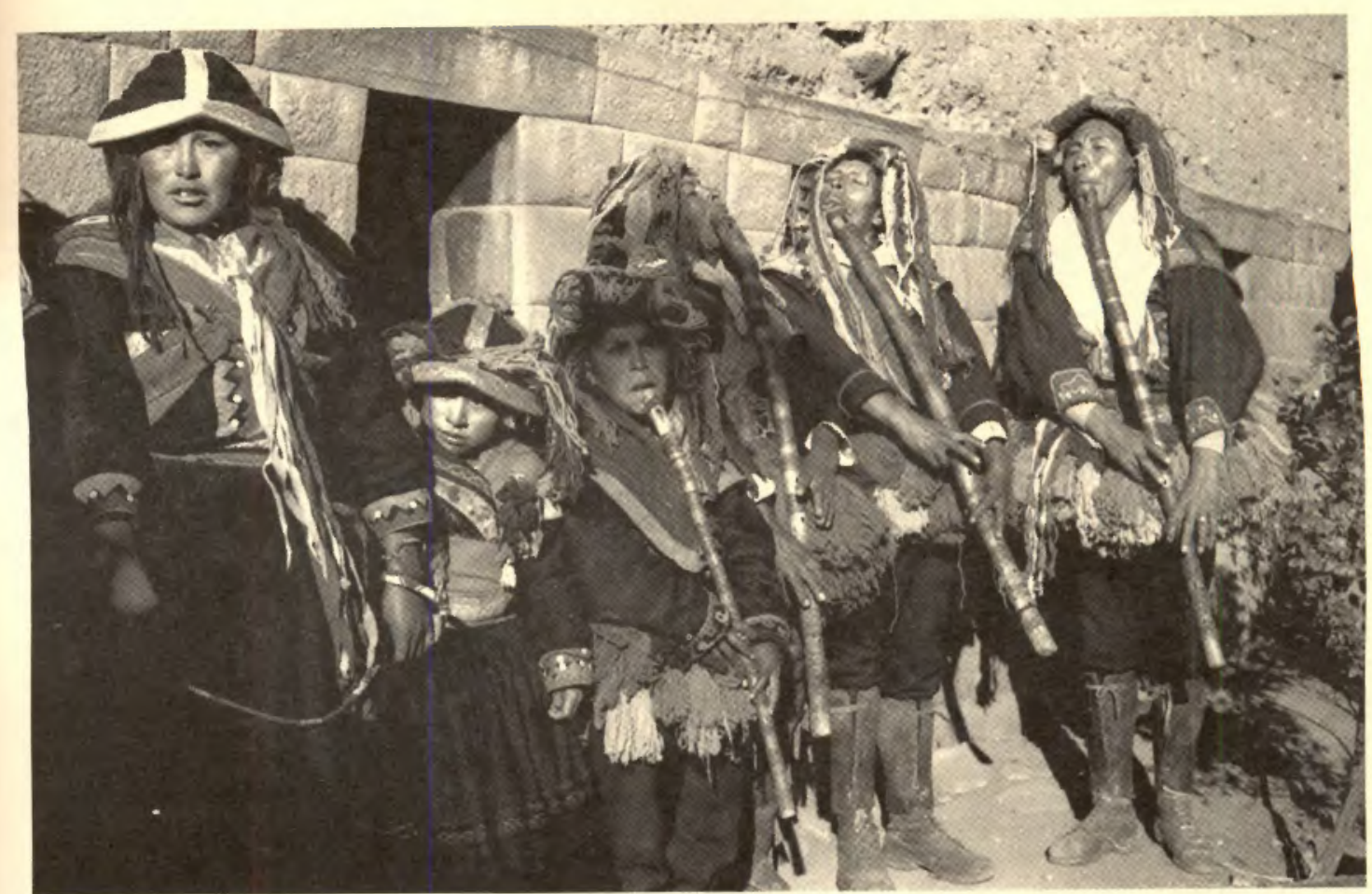

- Familia de Chucos con maro inca de fondo

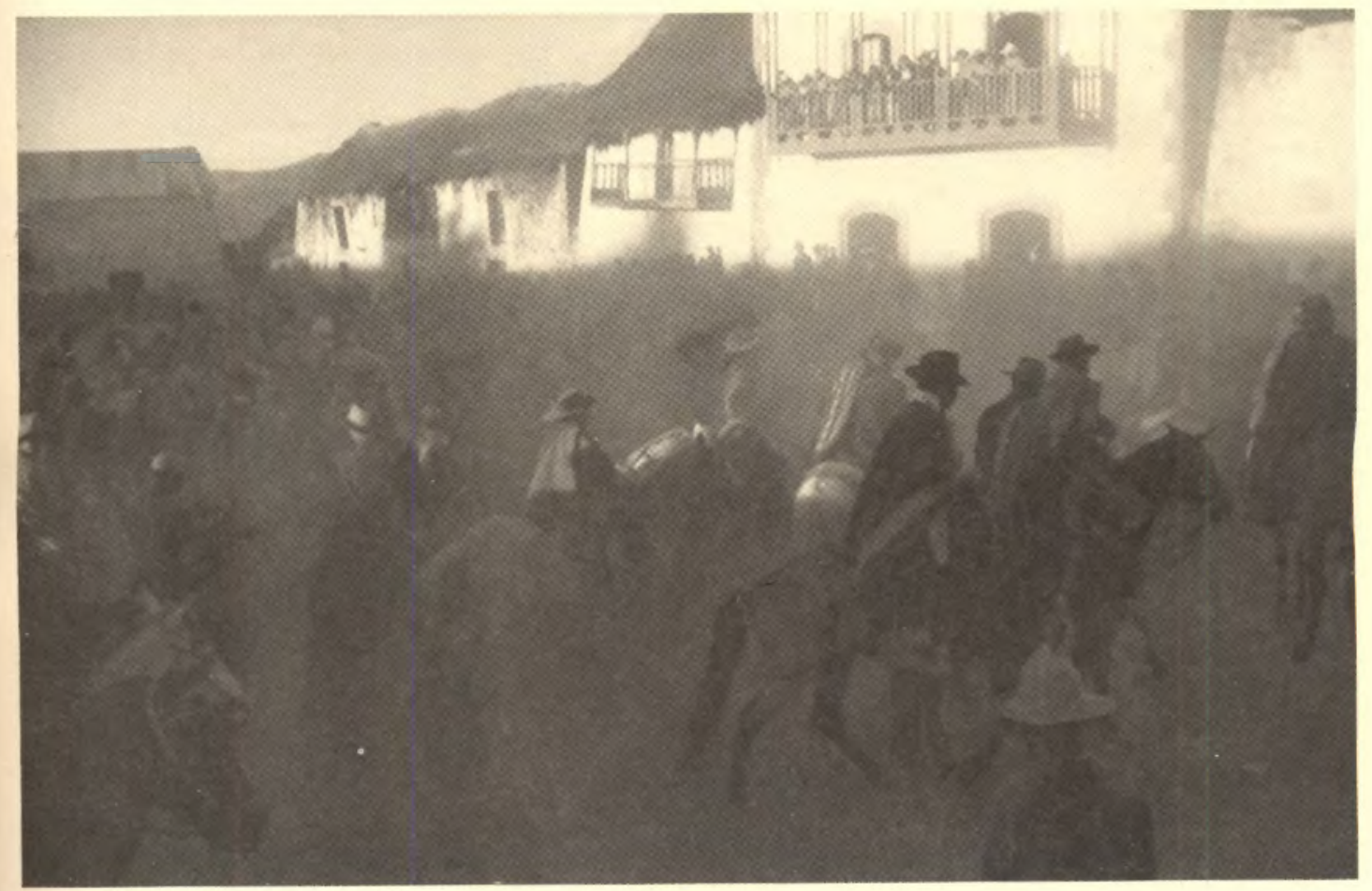

$\checkmark$ Gamonales entrando a Santo Tomás 


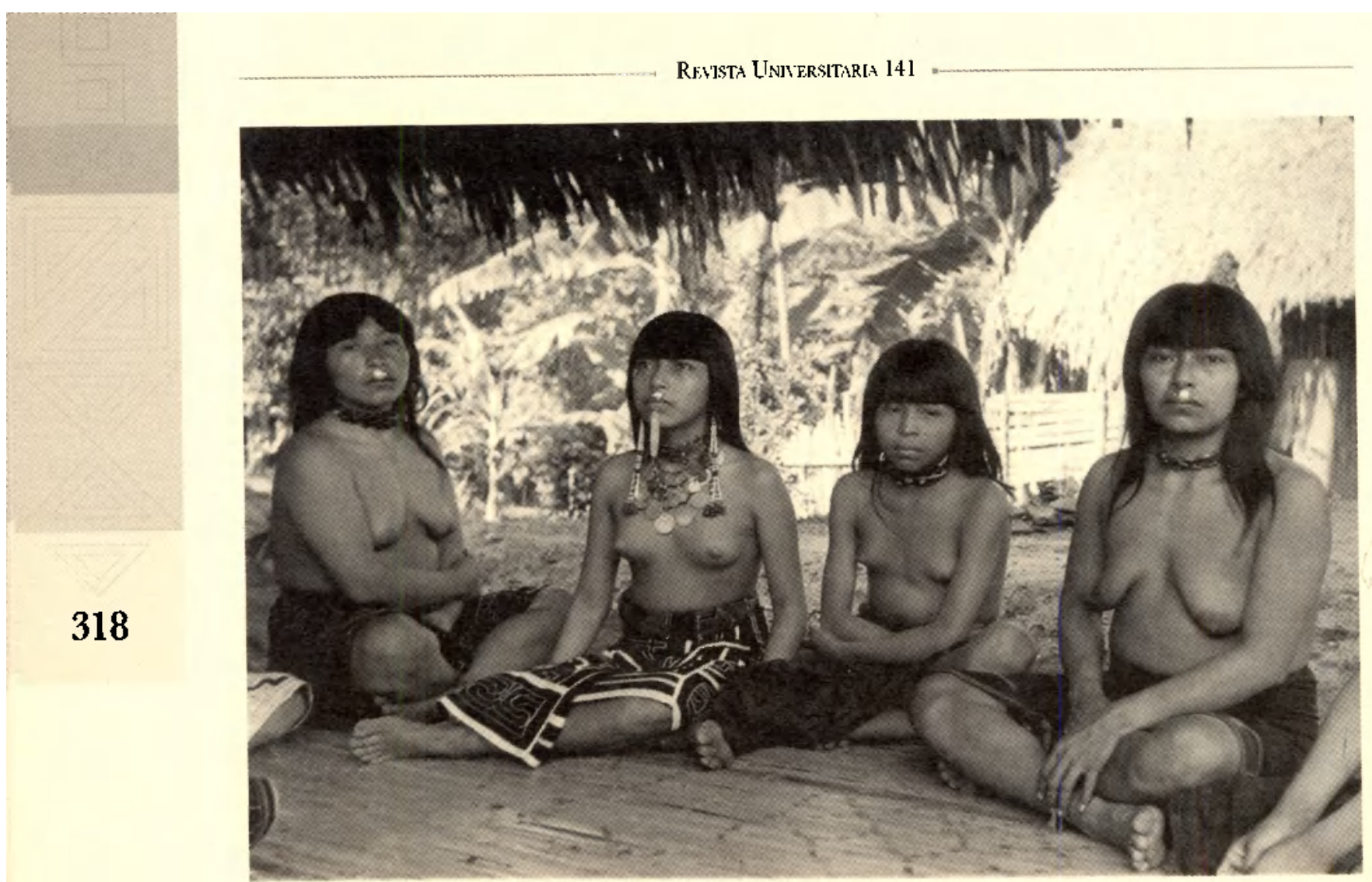

- Familia de mujer Shipiba.

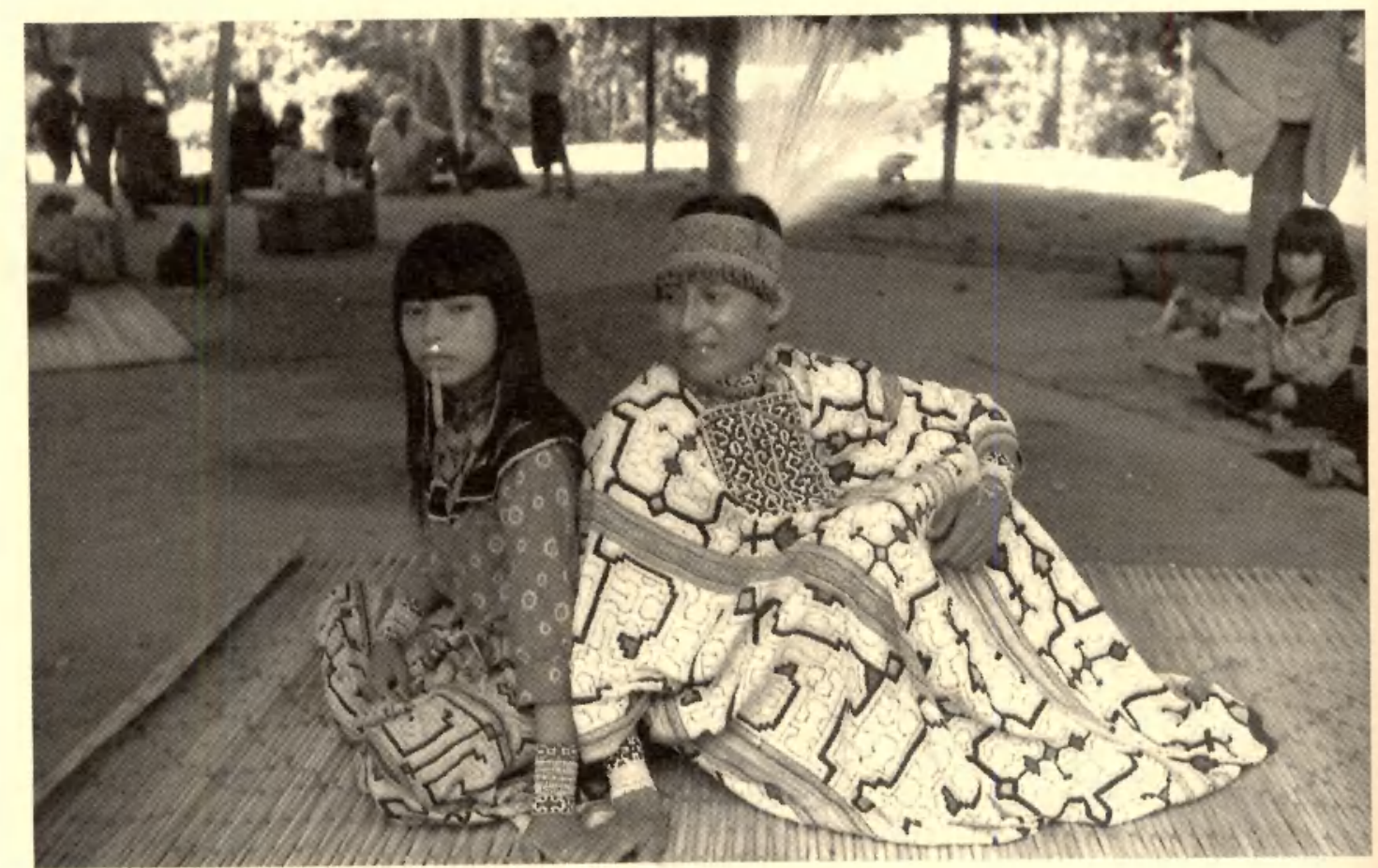




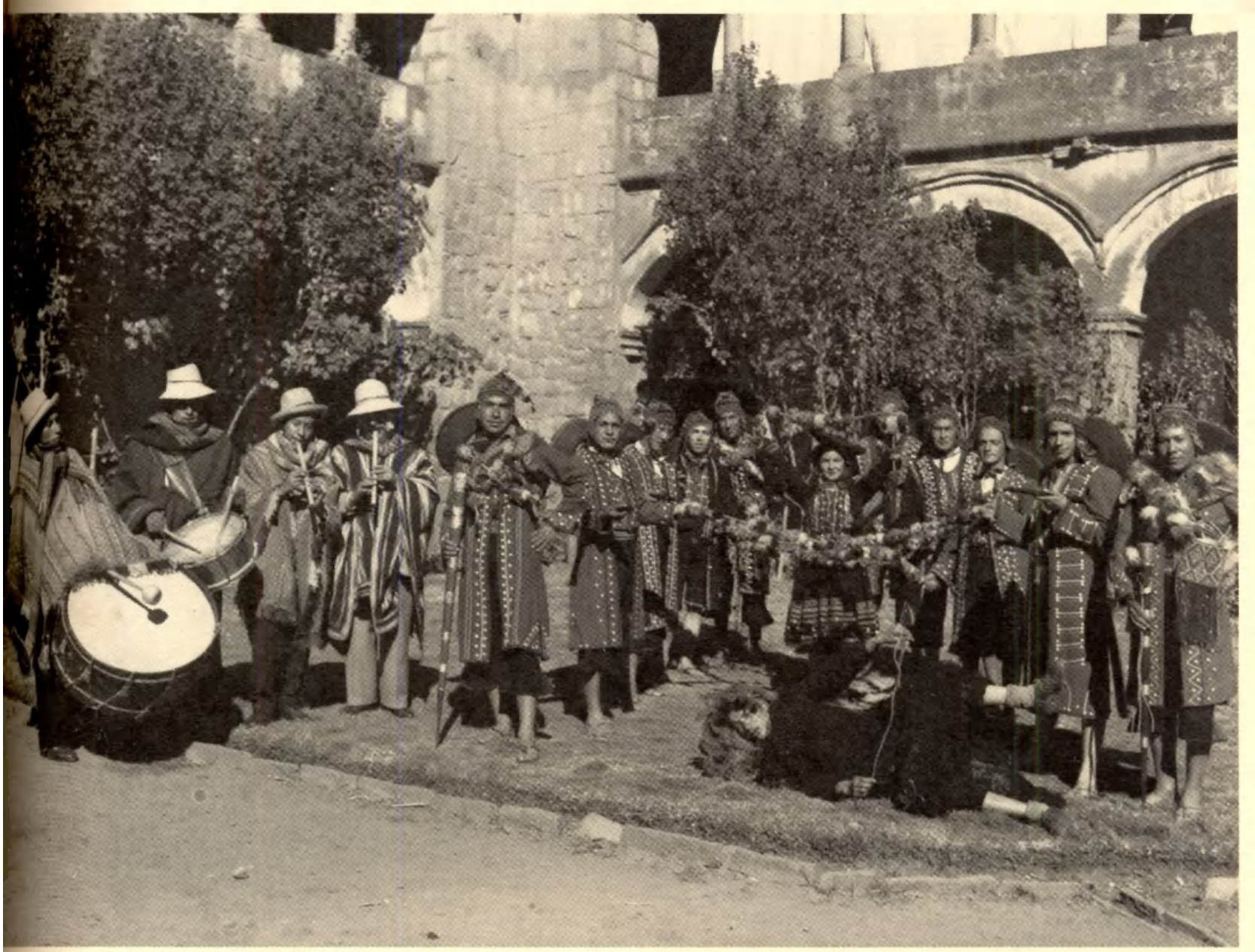

- Grupo artístico en patio colonial. 


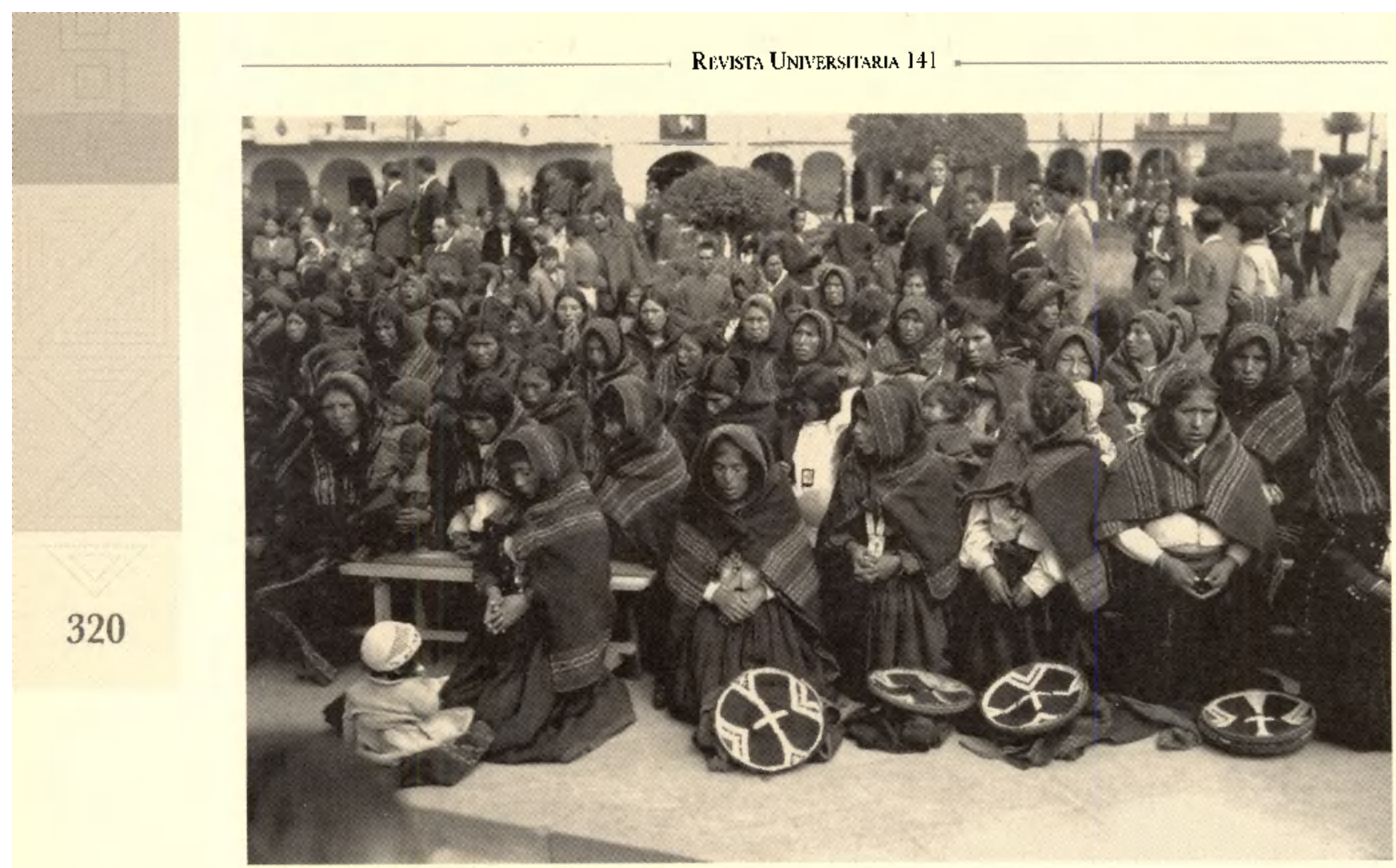

$\checkmark$ Laplegana.

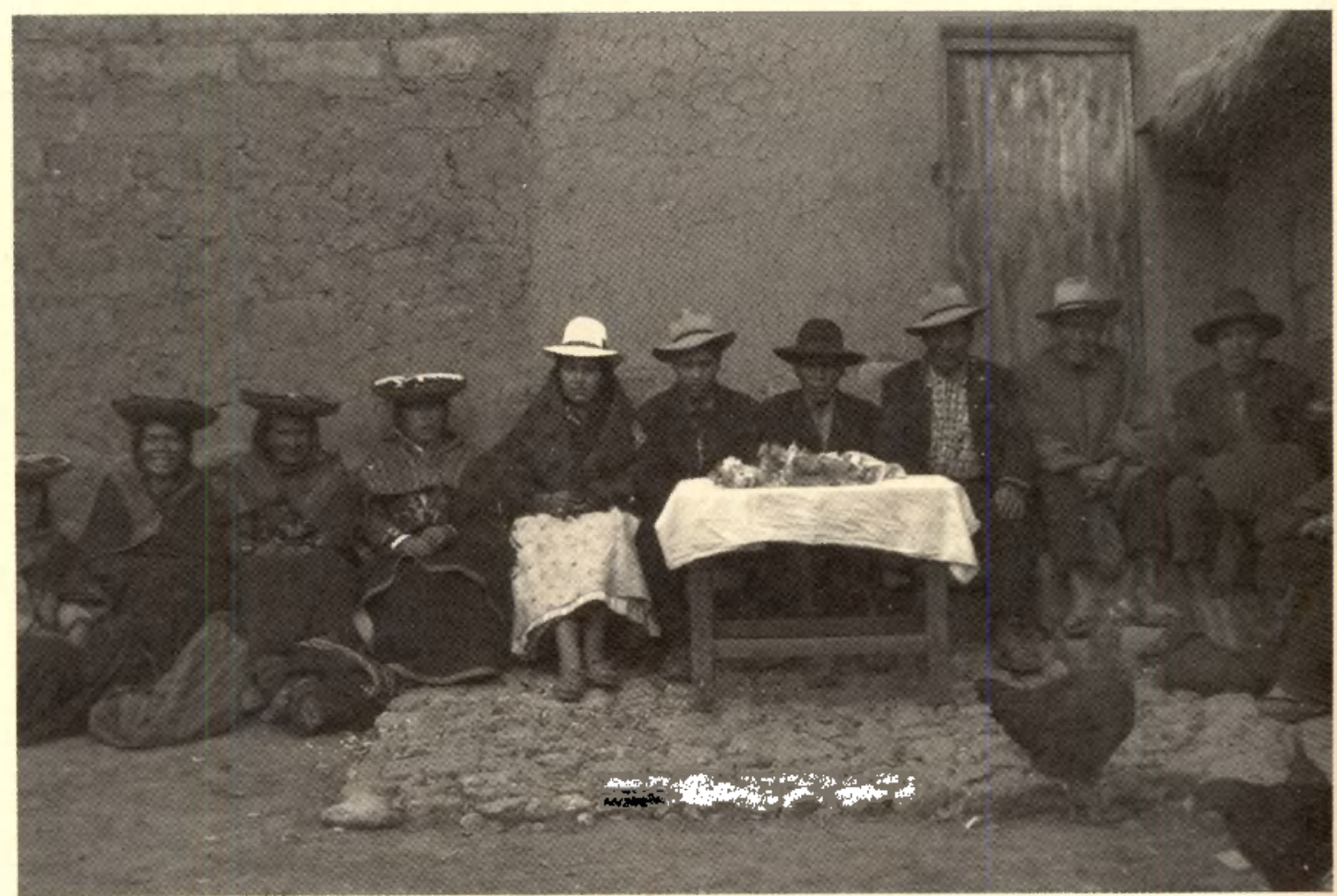




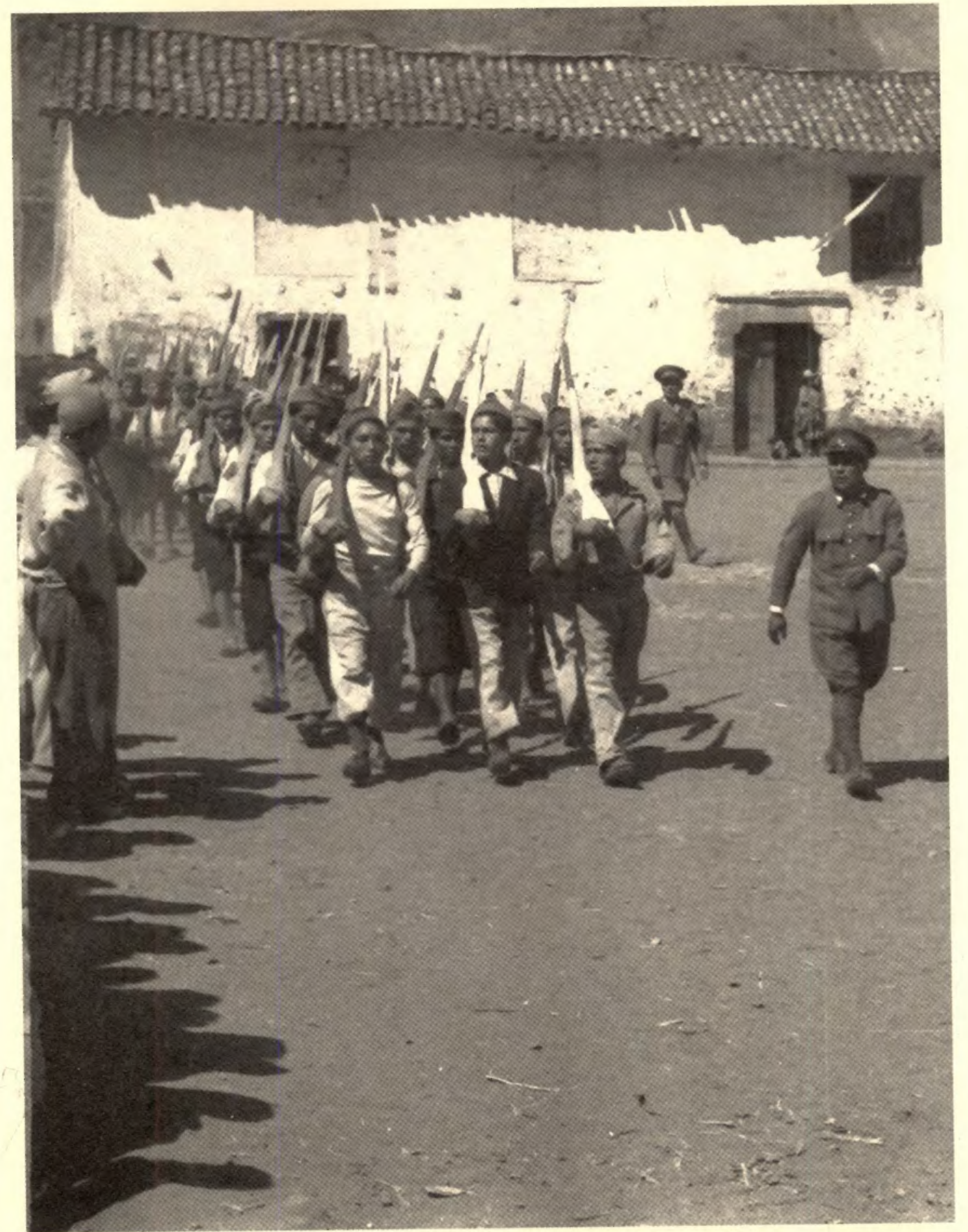

321

- Moolizables en Pisac. 


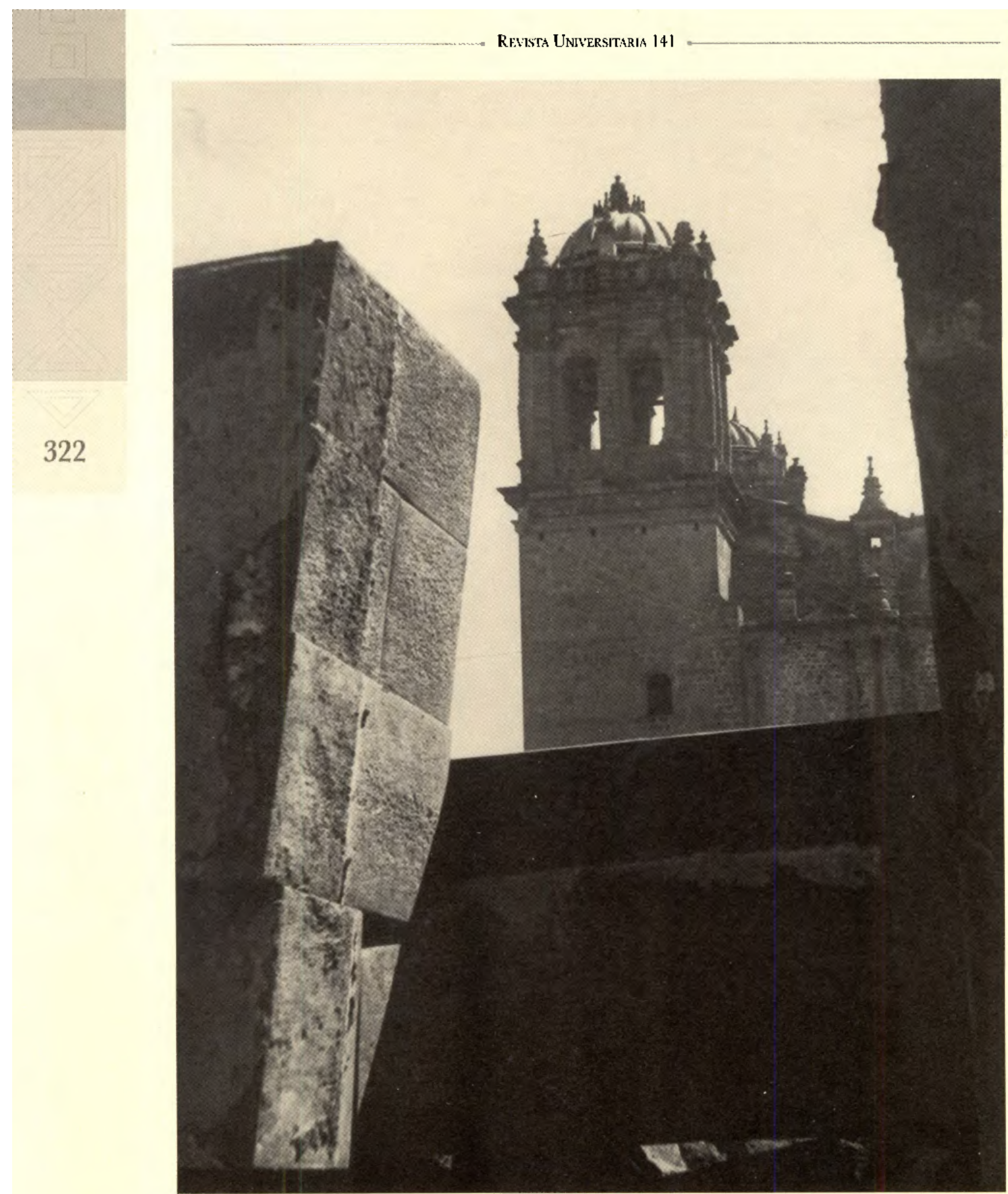

- Muro Inca con la Catedral al fondo. 


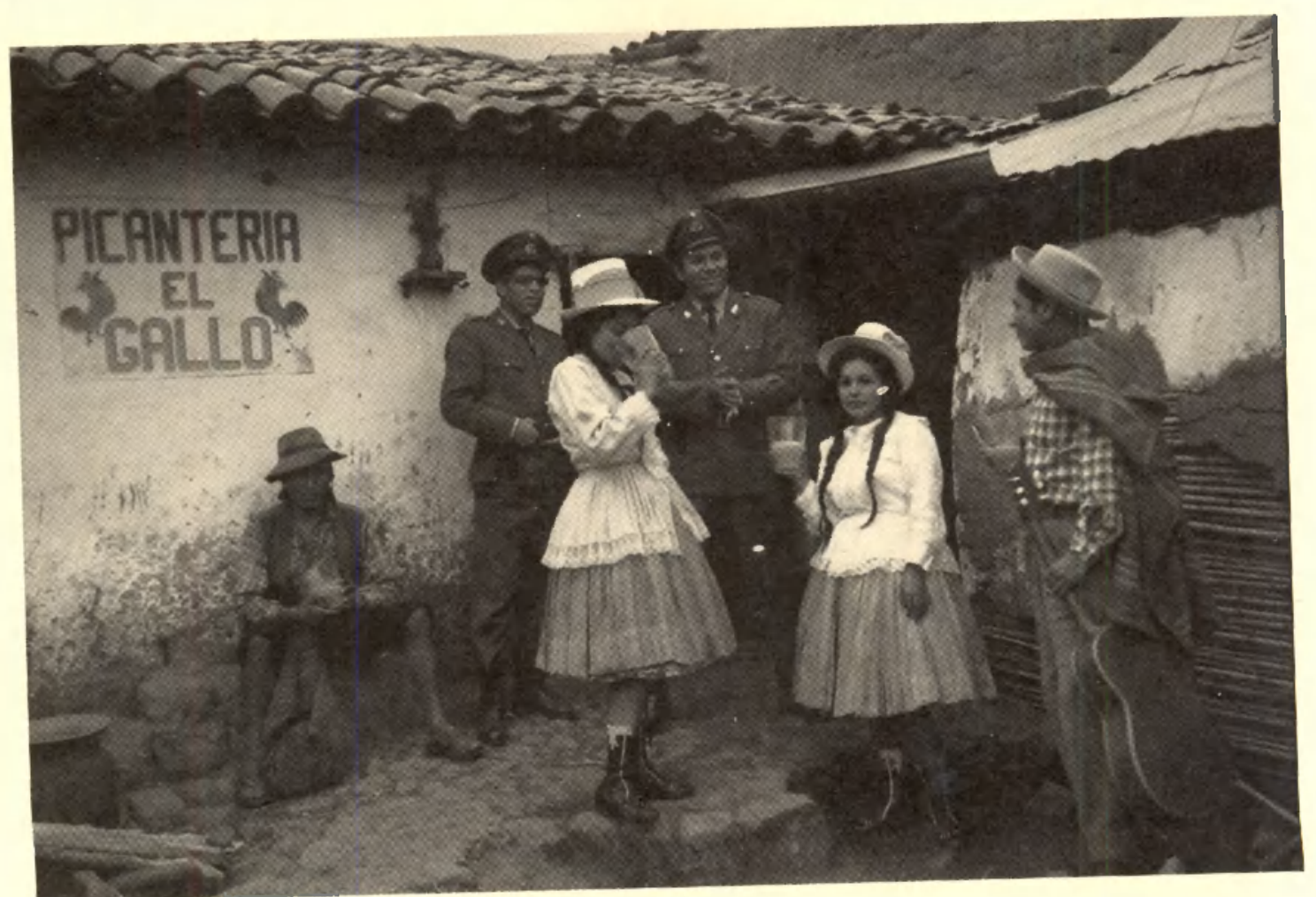

323

- Ptranterí El Gallo.

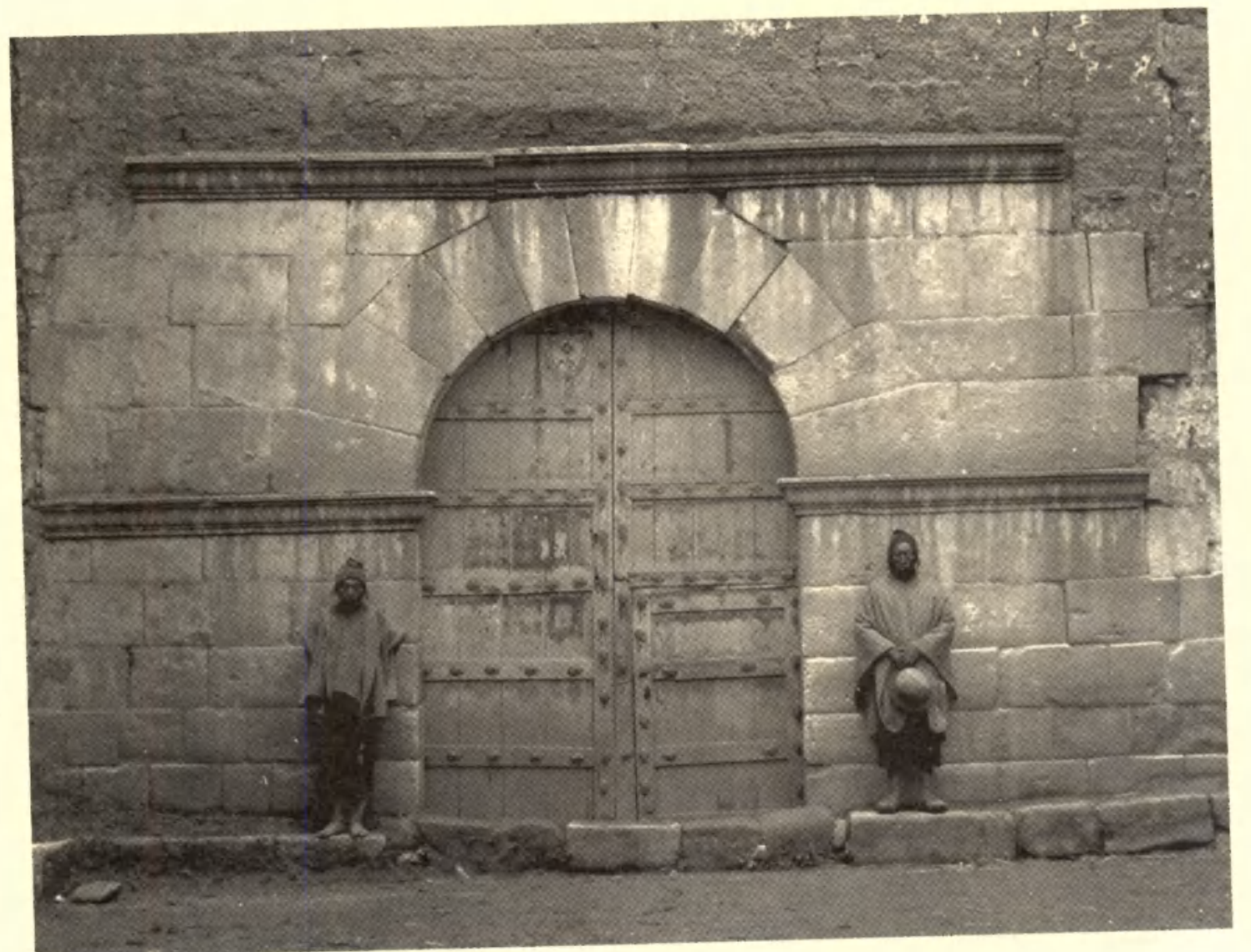




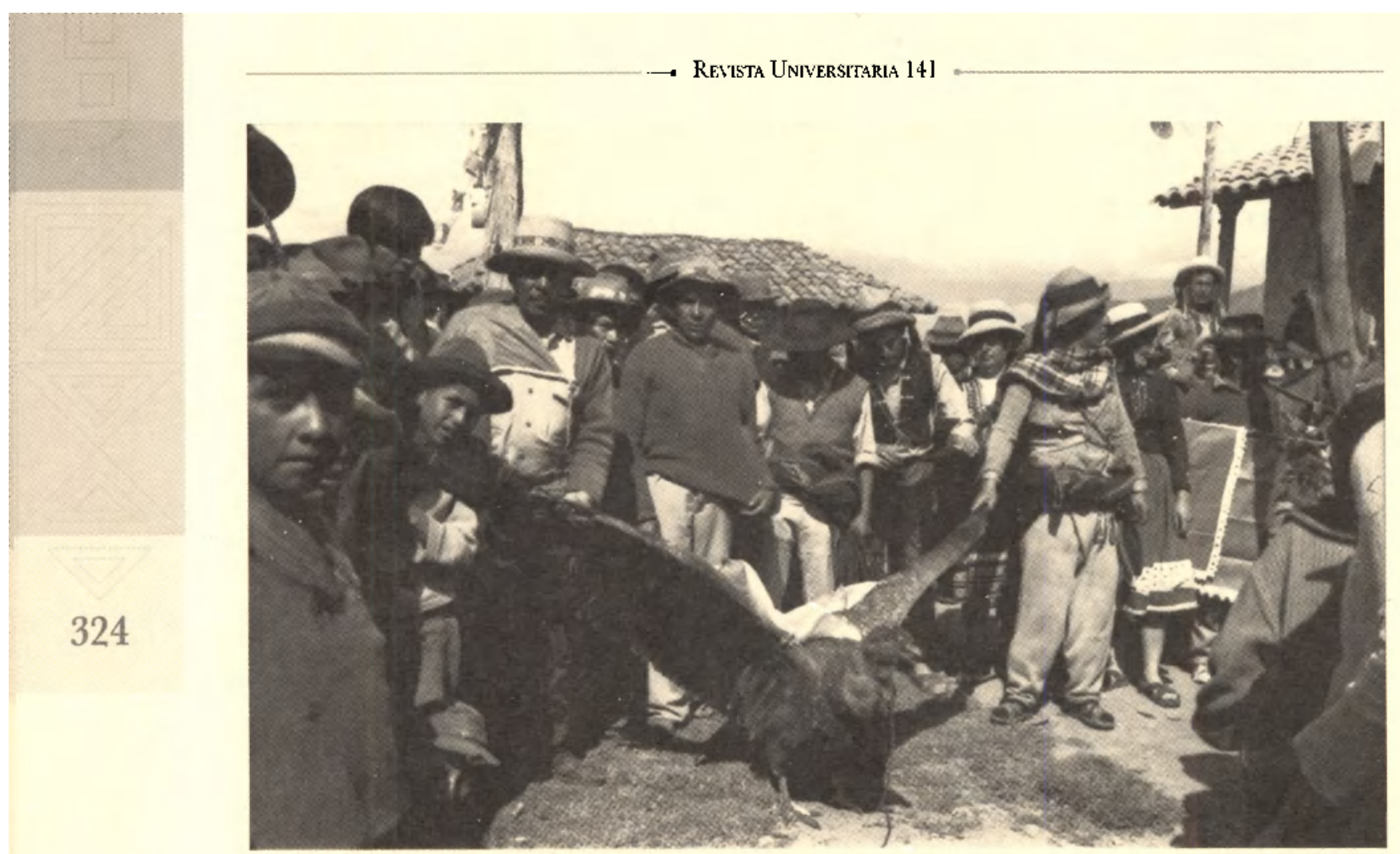

V Ritual del condor.

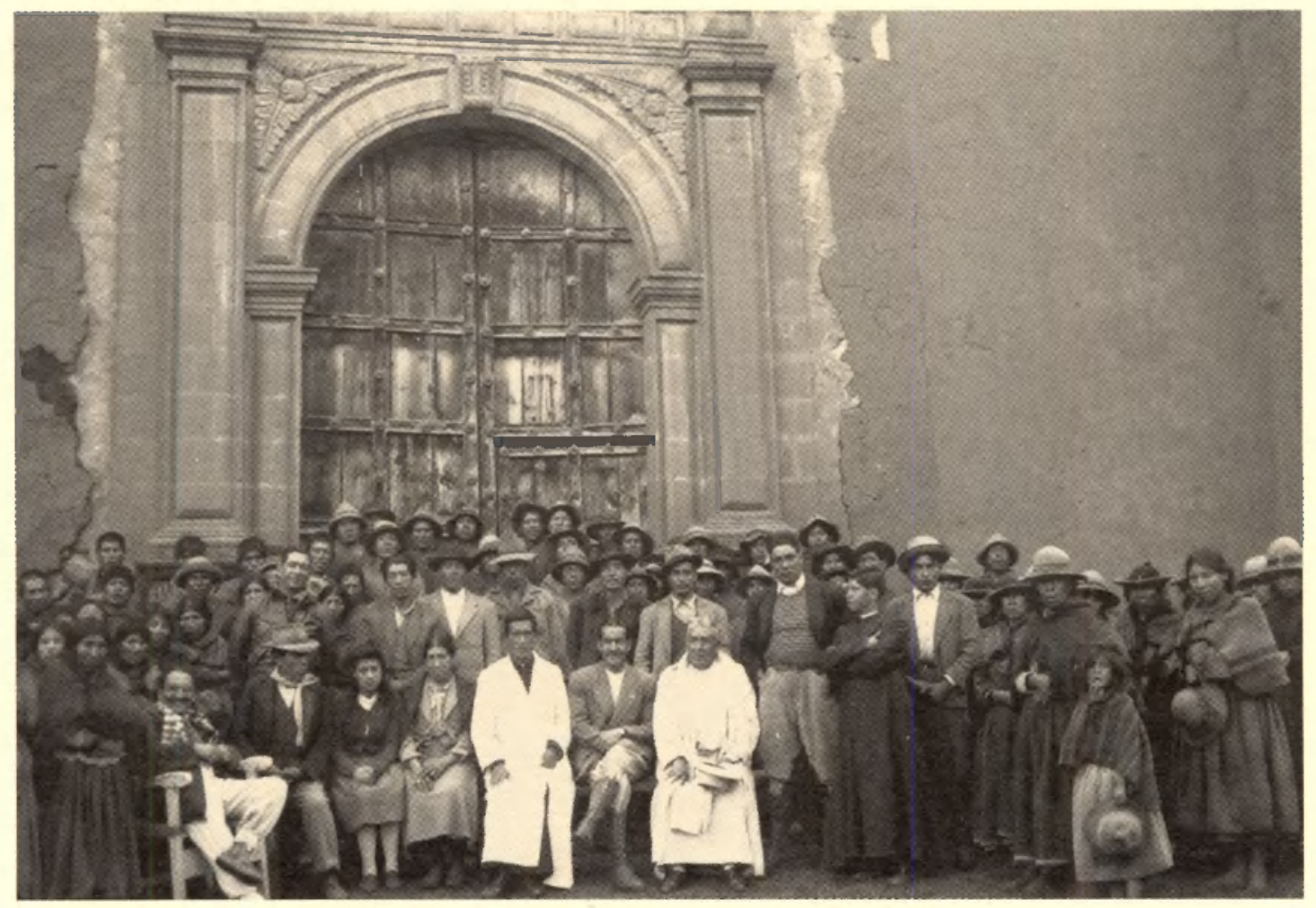

TSeñotes, mestizas e indias. 


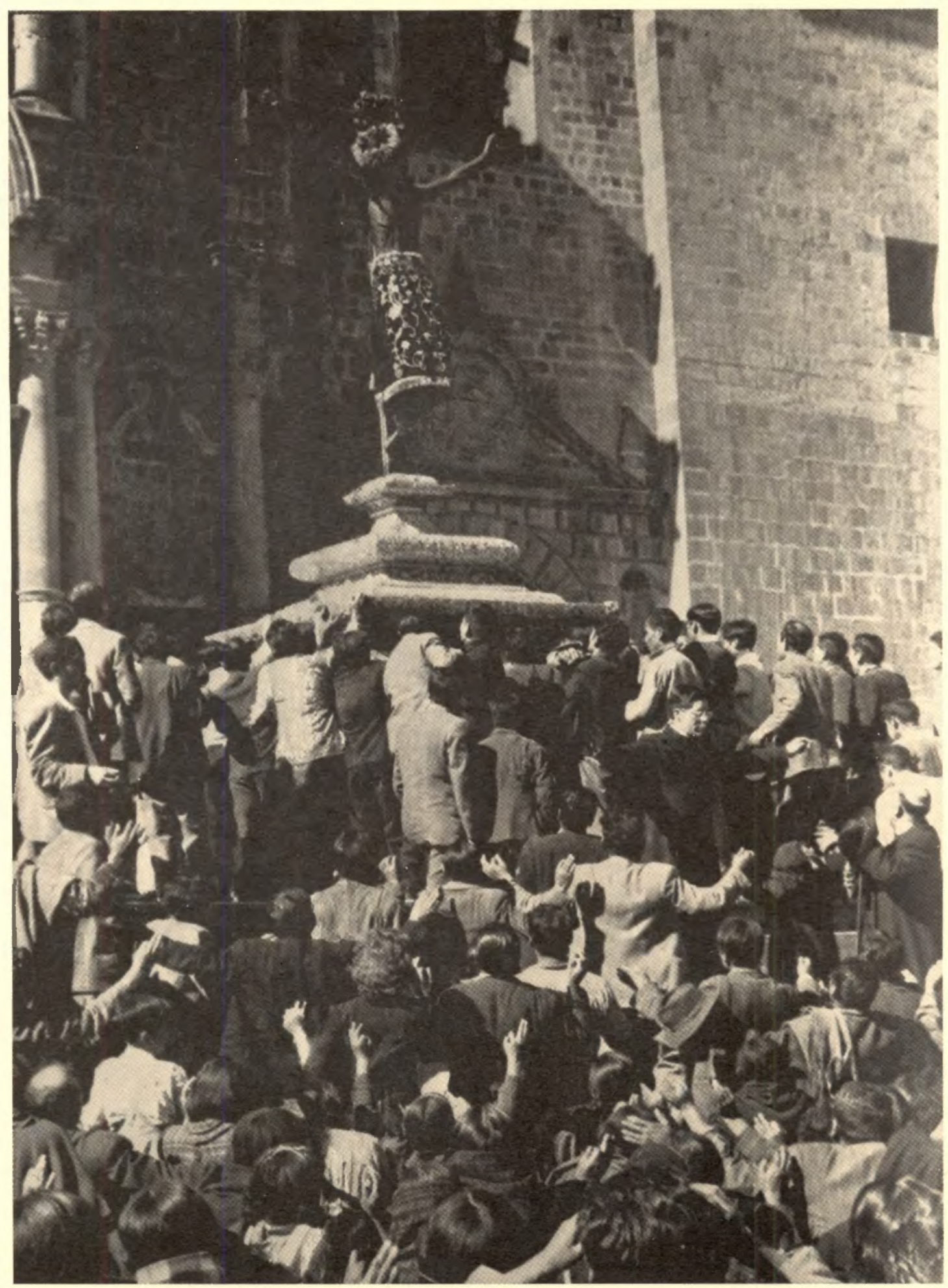




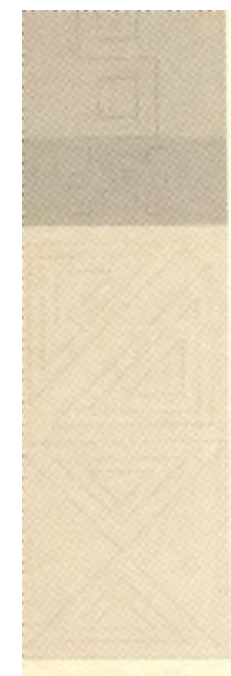

326

RevisTa UNIVERSTTARLA 141

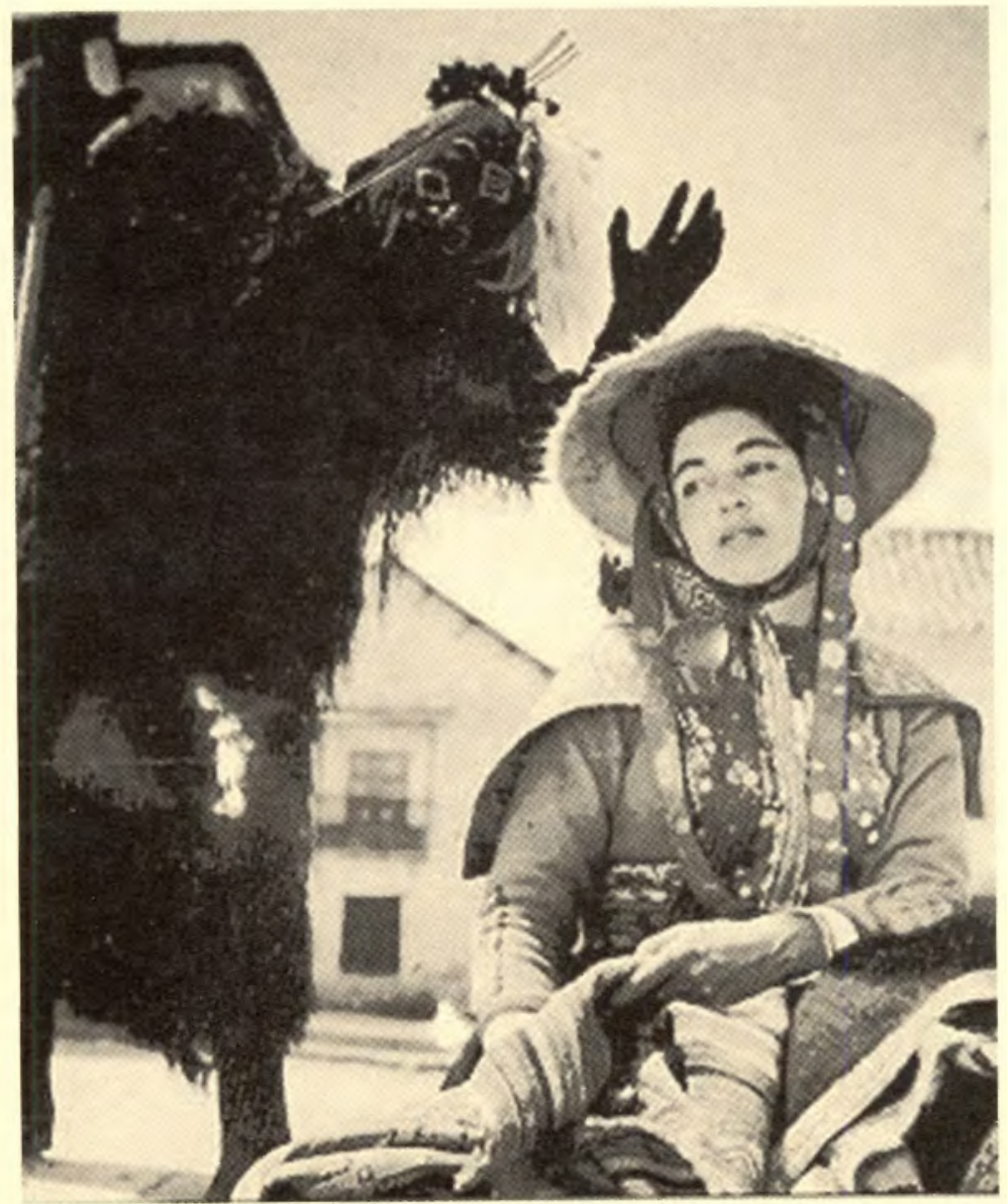

- Imagen fotogrifica de la primera pelicula en quechua "Kratuli".

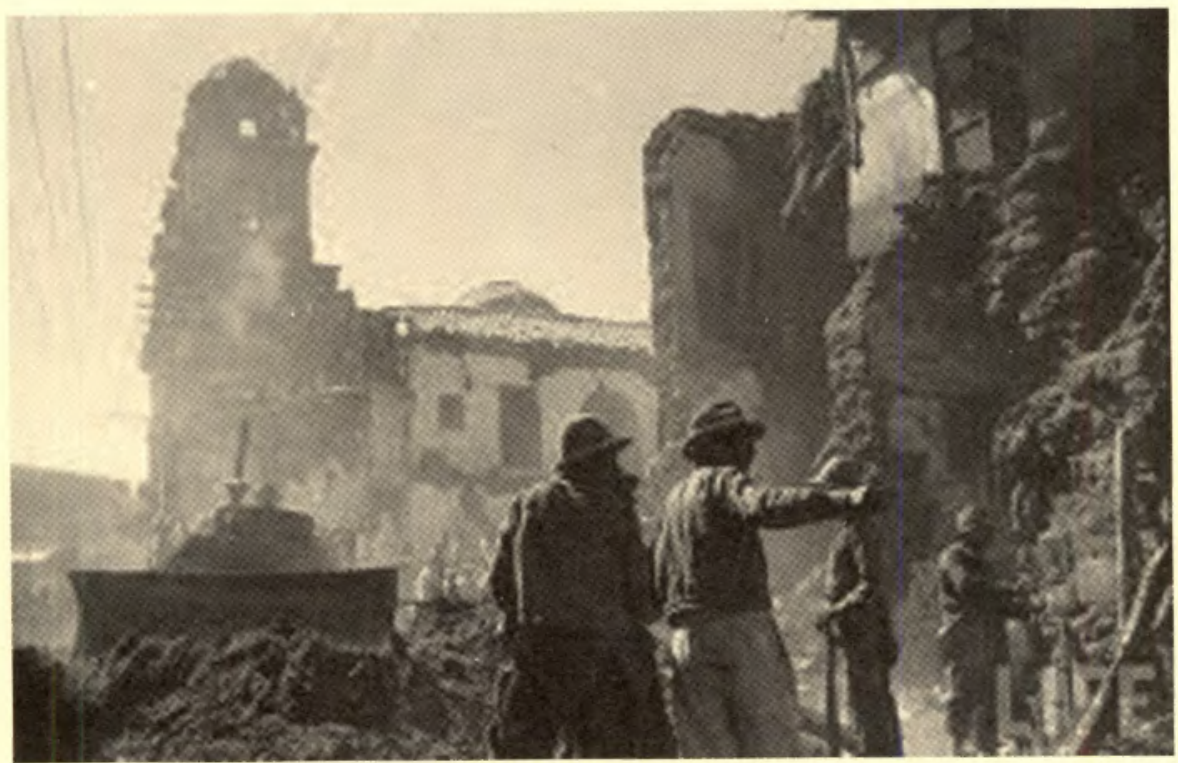

- Imagen fotogrófica del terremoto en Cusco en el año de 7950. 


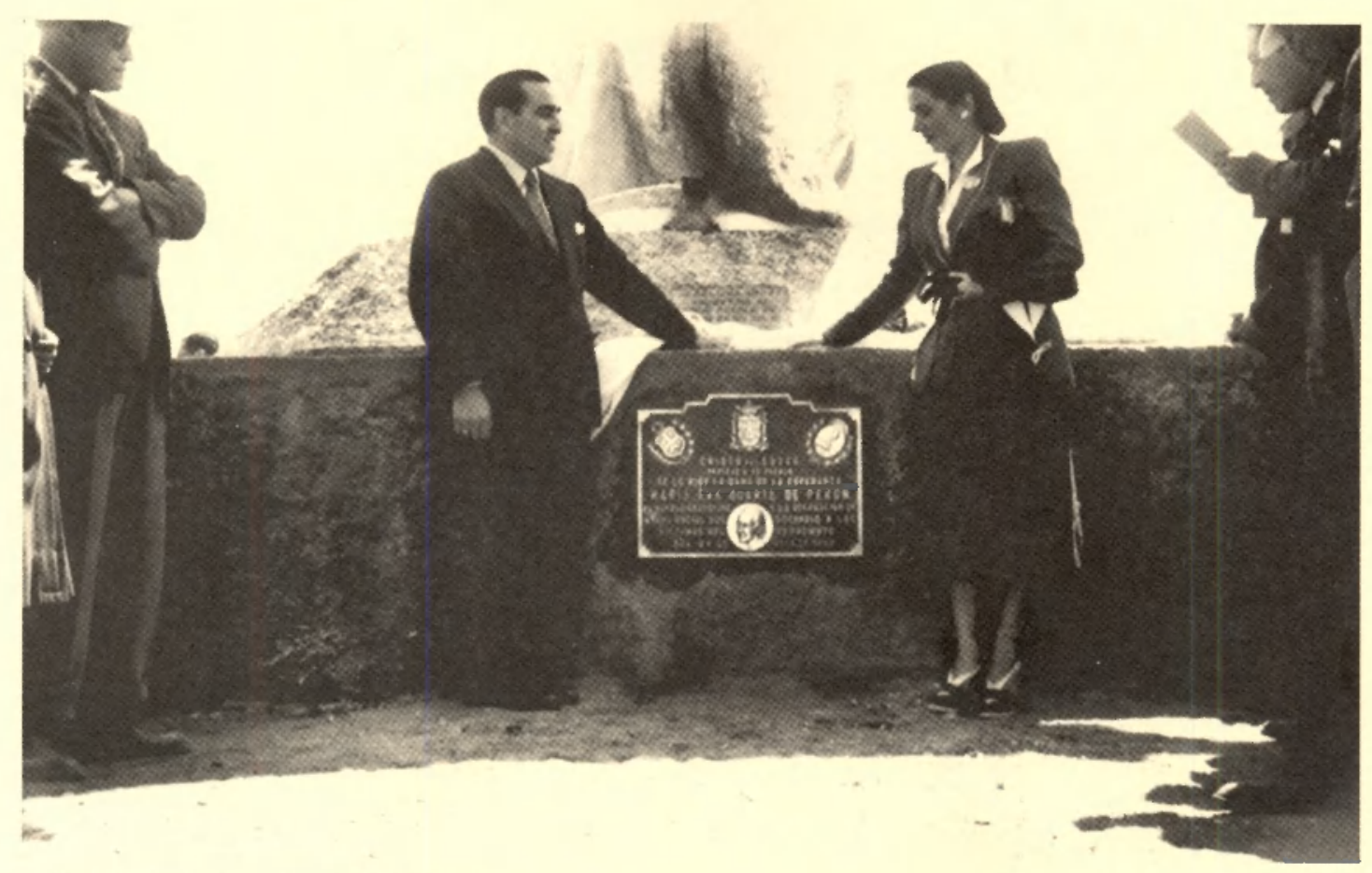

- Eva Perón. Develando una placa, al pre del Cristo Blanco.

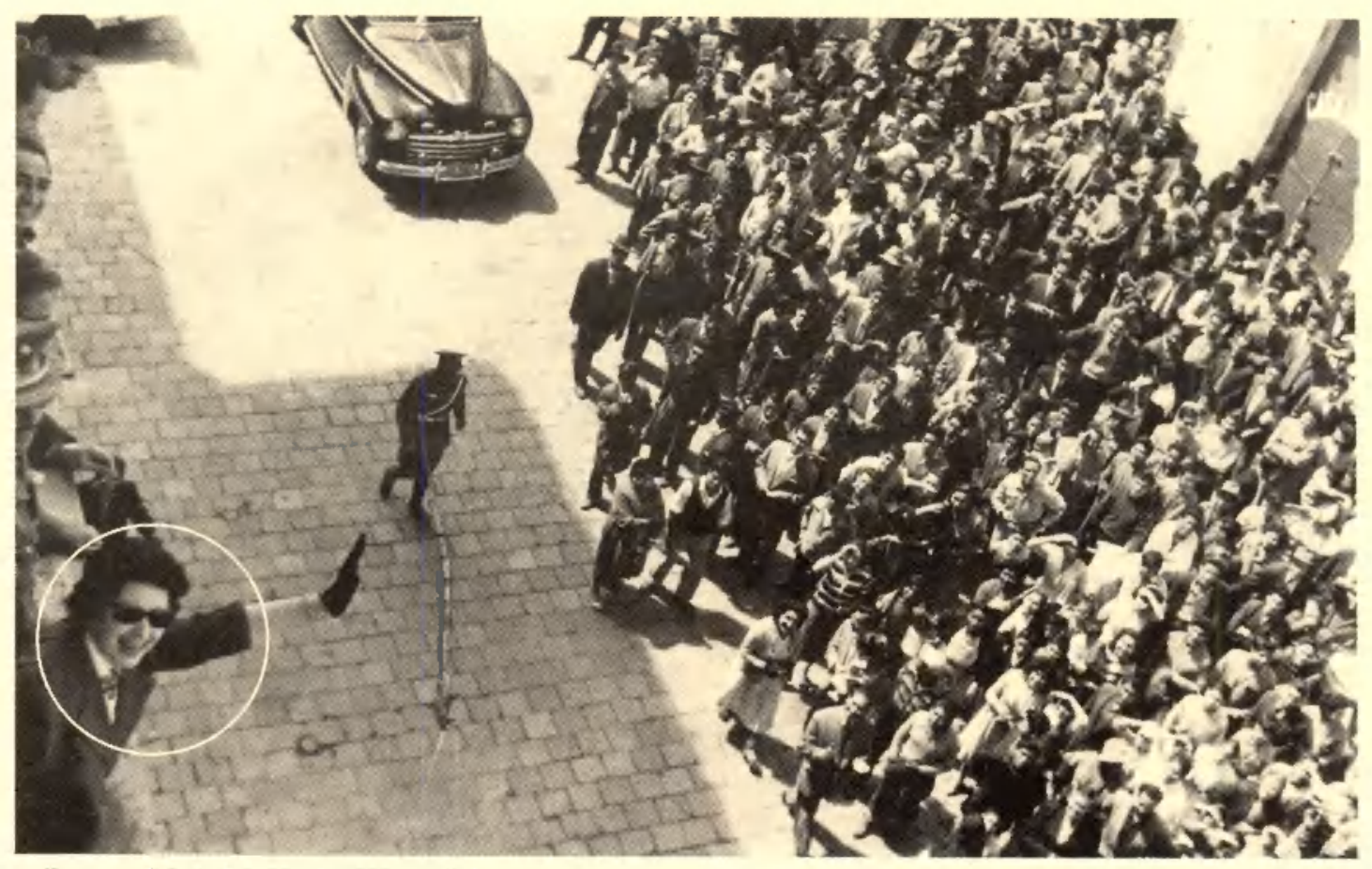

T Eva Duturte de Perón desde el balcoin del Hotel de Turistas 


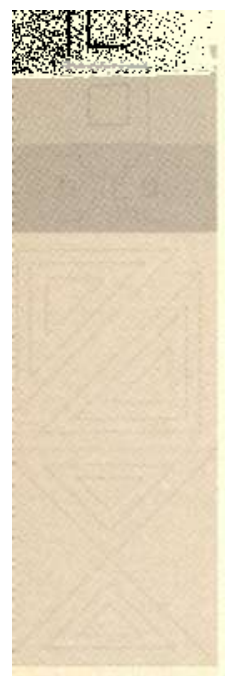

328

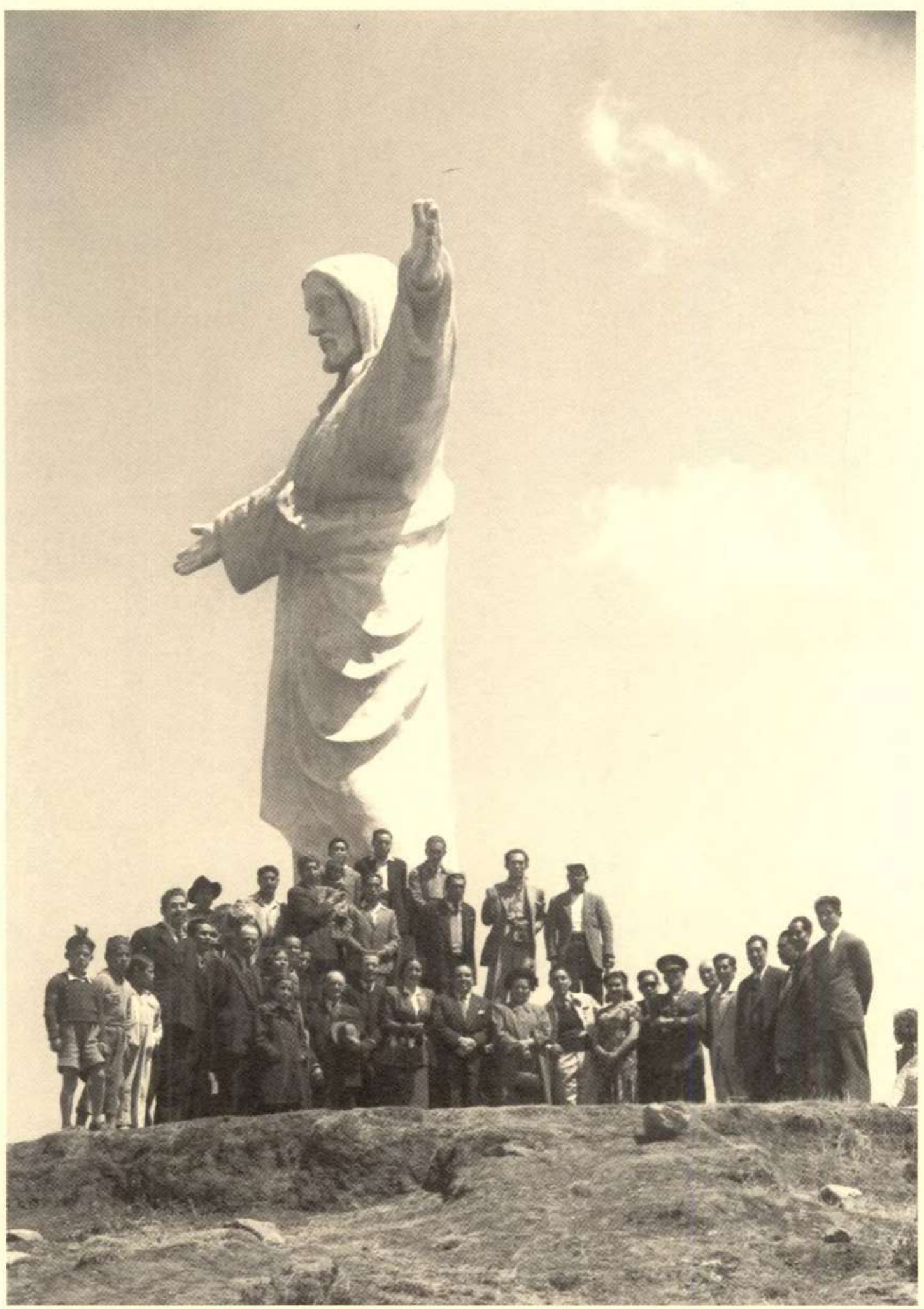

- Eva Perón al pie del Crista Blanco, Cuzza. 


\section{Garta de José María Arguedas A EULOGIO NISHIYAMA}

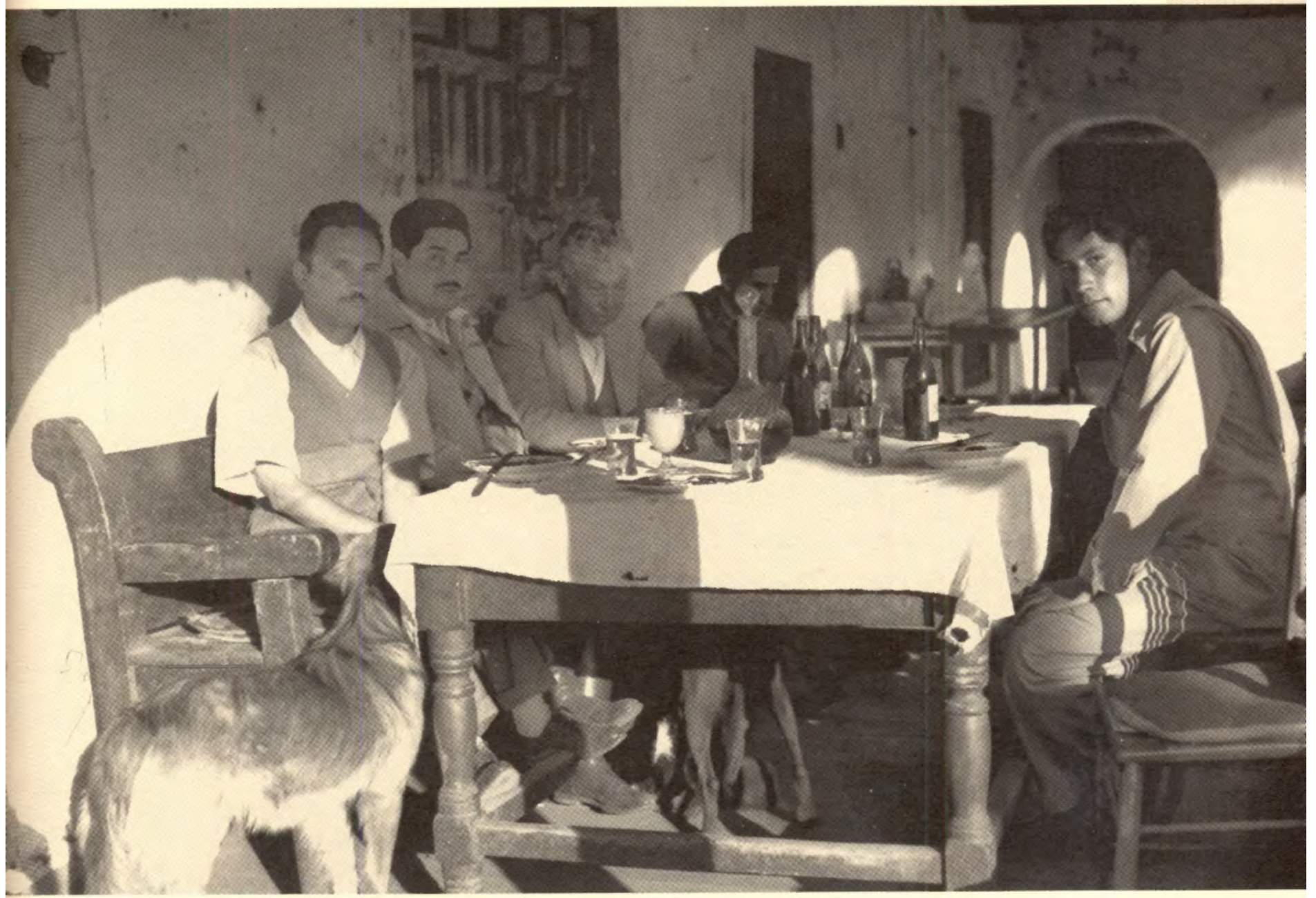

7 José Maria Arguedas: Hactenda Huarán. 
R \ISTA UNTTERSTTARTA I 41

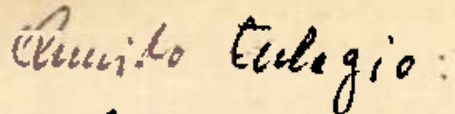

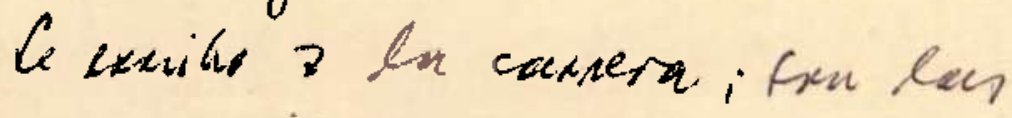
$10.35 \%$ an 7 ecealen he kecilier on. tulegrama. Gahivan to retaller.

330

En o Rrivin he lumes 10 Slegan

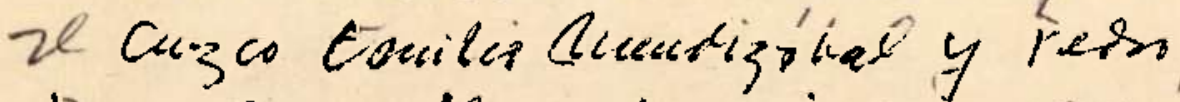

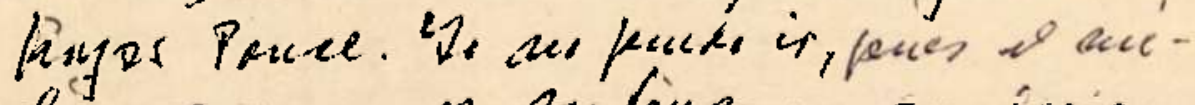

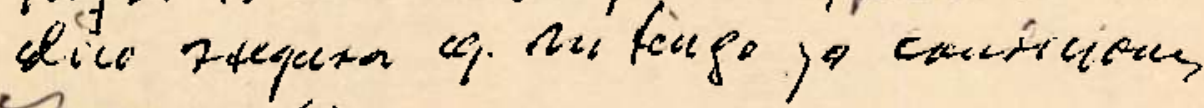
quane Ballir.

hlenarain nun lishuaborn bienent

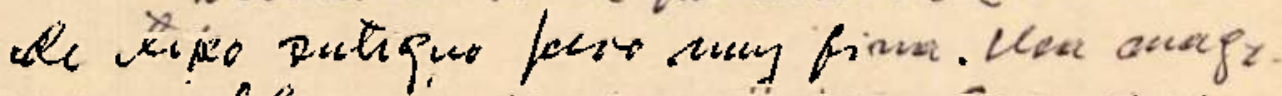

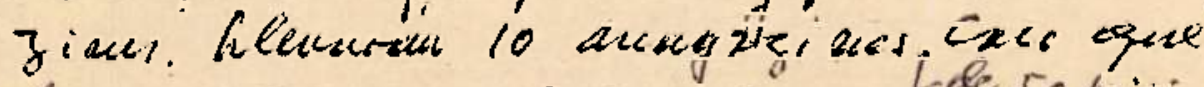

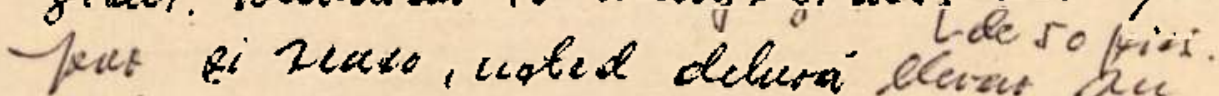

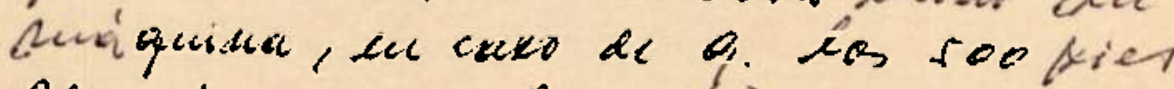

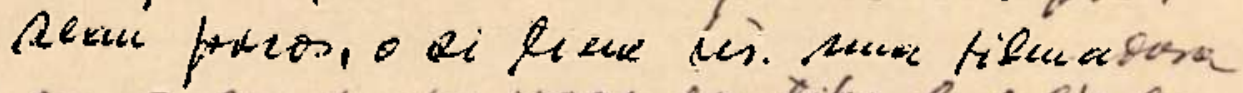
en $q$. de funta usat in tifer hr fuliada.

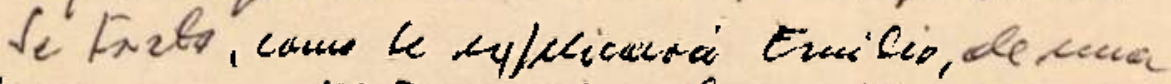

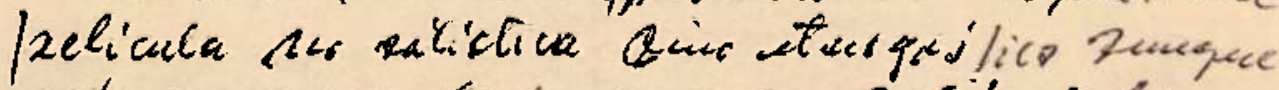

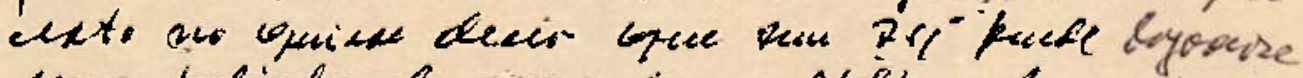

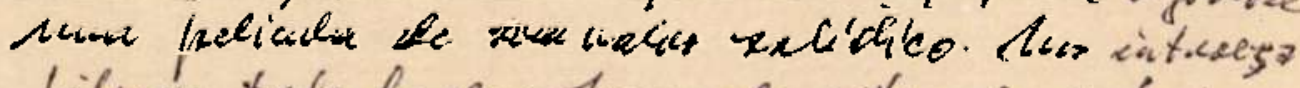

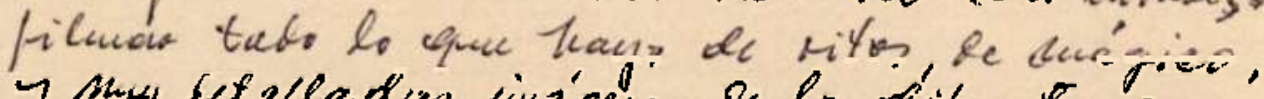

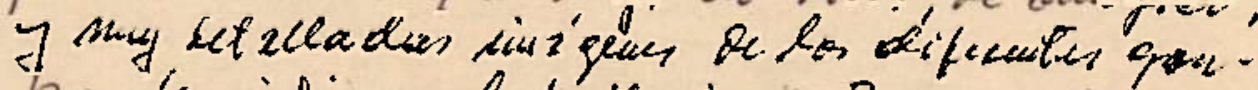

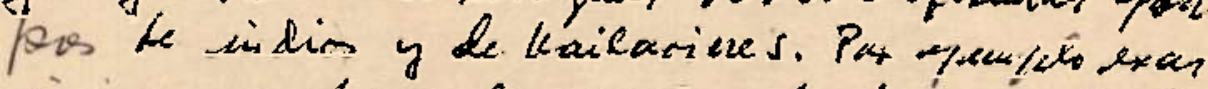

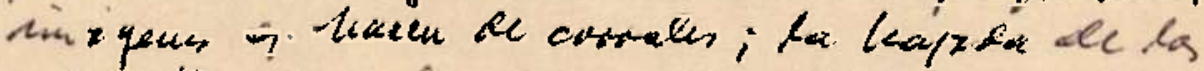

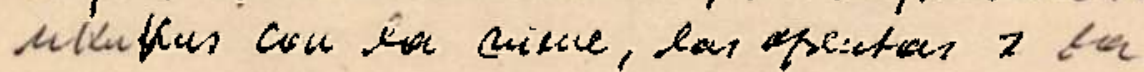


- 100 añs

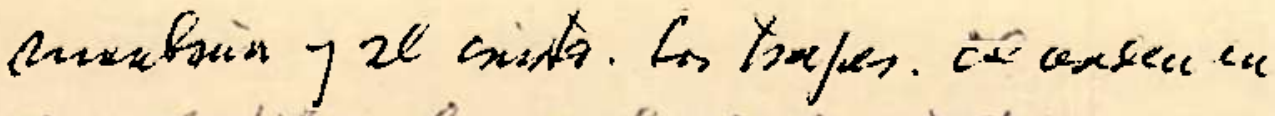

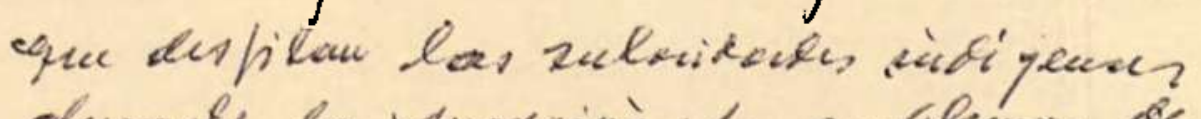

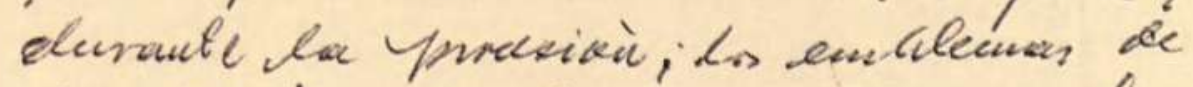

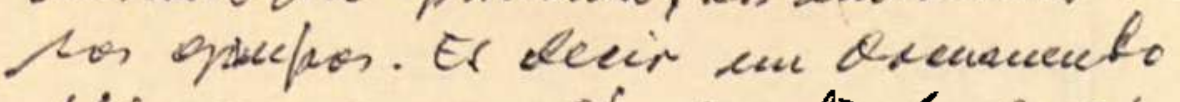

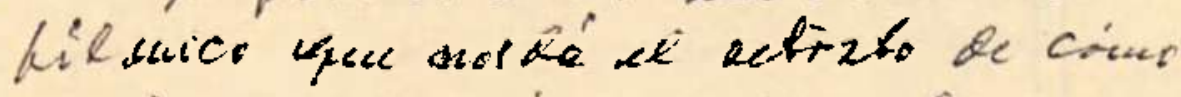

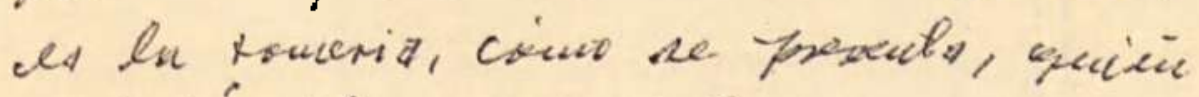

331

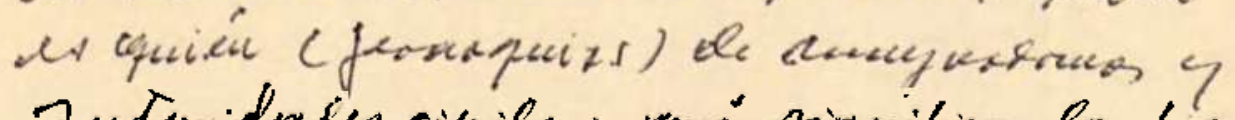

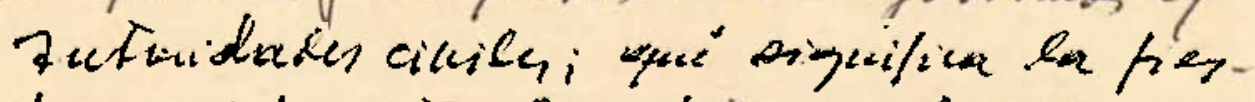

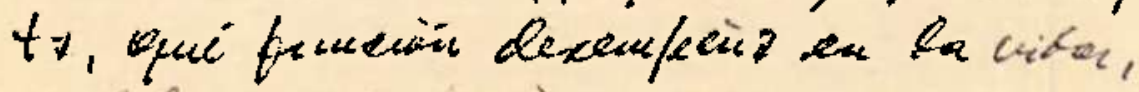

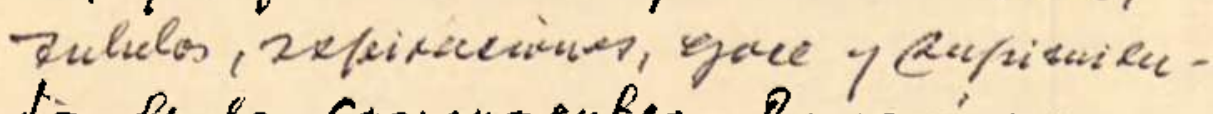
fis de tos conceurseuter. "Por copué mane,

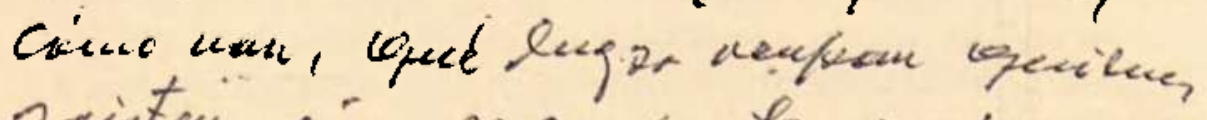

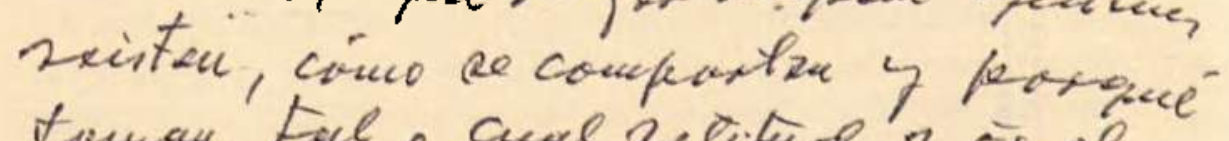
tuman Fall. ande zetitad? is el

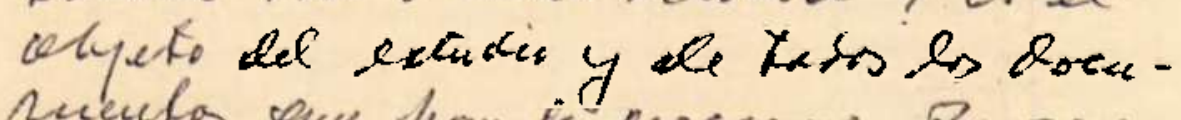

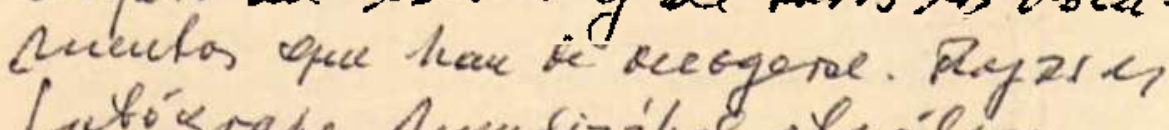
futógrapo, Aueutiziket elno'bago.

lestod noy envizai un kecileo lor

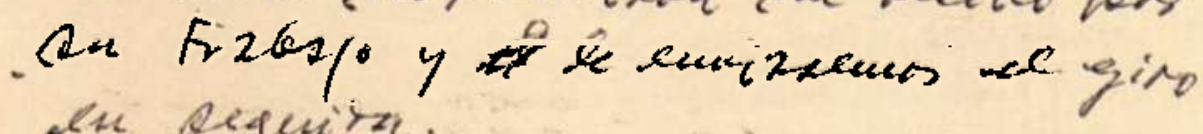
en Qeguitz.

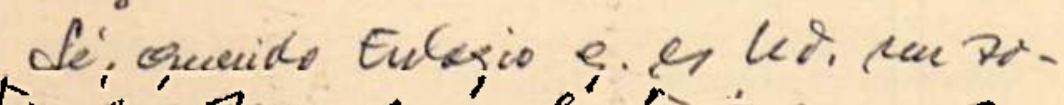

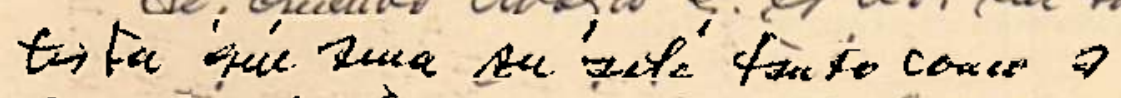

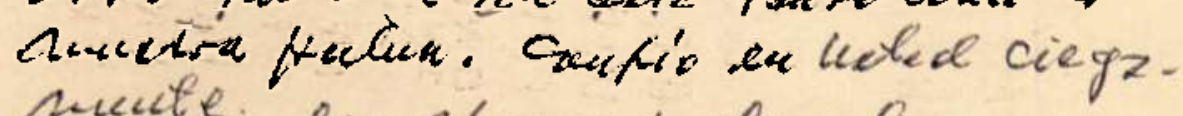
nunte en sbiaz' froderuel. freicheace. 
Querido Eulogio:

Le escribo a la carrera; son las 10.35 p.m. y acabo de recibir su telegrama. Ahí van los detalles.

En el avión del lunes 10 llegan al Cuzco Emilio Mendizábal y Pedro Rojas Ponce. Yo no puedo ir, pues el médico asegura que no tengo ya condiciones para salir.

Llevarán una filmadora Siemens de tipo antiguo pero muy fina. Usa magazines. Llevarán 10 magazines de 50 pies. Creo que por si acaso, usted deberá llevar su máquina, en caso de que los 500 pies sean pocos, o si tiene Ud. una filmadora en que se pueda usar ese tipo de película.

Se trata, como le explicará Emilio, de una película no artística sino etnográfica aunque esto no quiere decir que aun así puede lograrse una película de valor artístico. Nos interesa filmar todo lo que haya de mitos, de mágico, y muy detalladas imágenes de los diferentes grupos de indios y de bailarines. Por ejemplo esas imágenes que hacen de corrales; la bajada de los ukukus con la nieve, las ofrendas a las montaña y al cristo, los trajes. El orden en que desfilan las autoridades indígenas durante la procesión; los emblemas de los grupos. Es decir un documento filmico que nos dé el retrato de cómo es la romería, cómo se presenta, quién es quién (jerarquías) de mayordomos y autoridades civiles; qué significa la fiesta, qué función desempeña en la vida, anhelos, aspiraciones, goce y sufrimiento de los concurrentes. ¿Por qué van, cómo van, qué lugar ocupan quienes asisten, cómo se comportan y por qué toman tal o cual actitud? Es el objeto del estudio y de todos los documentos que han de recogerse. Rojas es fotógrafo, Mendizábal etnólogo.

Usted nos enviará un recibo por su trabajo y le enviaremos el giro en seguida.

Sé, querido Eulogio, que es Ud. un artista que ama su arte tanto como a nuestra patria. Confio en usted ciegamente.

Un abrazo fraternal, 


\title{
El Museo de LA Ciasa Concha
}

\author{
Jean-Jacques Decoster
}

La Casa Concha, construida dentro del perímetro de Puka Marka, que fue la cancha de la panaca de Tupa Inca Yupanqui, ha recibido desde 2011 las piezas excavadas por Hiram Bingham en Machu Picchu en 1912 y devueltas por la universidad de Yale en cumplimiento del Memorando de Entendimiento firmado en 2010.

La adecuación de la Casa Concha como museo era parte del compromiso de la UNSAAC, en los términos de este Memorando, de proveer un museo para recibir los materiales arqueológicos devueltos. Al momento de esos acuerdos, la Casa Concha se encontraba en proceso de restauración, liderado por equipos del INC y de la Universidad, luego de la entrega del edificio a la UNSAAC por el Presidente Valentín Paniagua.

El largo trabajo de restauración culminó en 2010. Es ejemplar el resultado de la rehabilitación, considerando que la casona colonial había sido durante buena parte del siglo XX cuartel del Ejército, luego Comisaría y oficinas de la Policía de Investigaciones. Los expertos en restauración, no solo pudieron rescatar la arquitectura neo inca (fotografia $\mathrm{N}^{\circ}$ 1, fotografia $\mathrm{N}^{\circ}$ 2) y colonial (fotografia $\mathrm{N}^{\circ} 3$, fotografia $\mathrm{N}^{\circ} 4$, fotografia $\mathrm{N}^{\circ} 5$, fotografia $\mathrm{N}^{\circ}$ 6); además lograron salvar murales coloniales que habían sido ocultados por capas de cemento durante la ocupación de la casona por las instituciones castrenses (fotografia $\mathrm{N}^{\circ} 7$, fotografia $\mathrm{N}^{\circ} 8$ ).

En adición a sus funciones como museo, el edificio cuenta con almacenes y laboratorios para investigaciones. La antigua capilla de la Casa Concha sirve hoy de auditorio y sala de conferencias (fotografia $\mathrm{N}^{\circ}$ 9).

Se abre el museo en noviembre de 2011, para presentar al público la colección Machu
Picchu de la Universidad de Yale, cuyo retorno al Perú se había ido negociando a lo largo de varios años. En la actualidad, el museo Machu Picchu de la Casa Concha está conformado por una exhibición permanente abierta al público de aproximadamente 360 piezas, y otras 45000 piezas en depósitos cerrados, entre fragmentos de cerámica, líticos, y óseos -incluyendo 177 esqueletos humanos parciales.

La exhibición permanente reúne objetos de cerámica, metales y piedras, en su mayoría de fábrica inca, resultado de la excavación en Machu Picchu conducida en 1912 por el equipo de la Expedición Yale / National Geographic. A esos objetos se suman materiales incas adquiridos localmente; cerámicas, tejidos y platería en préstamo de otros museos; y cerámicas encontradas en excavaciones hechas en el contexto de la restauración de la Casa Concha a los inicios del siglo XXI.

¿Por qué es importante esta colección? Para empezar por el contexto histórico de la devolución exitosa, uno de los pocos ejemplos a nivel mundial, todavía, del retorno de Patrimonio Cultural a su lugar de origen. Allí, la gestión de varios gobiernos sucesivos, y la acción proactiva de la Universidad, han logrado asegurar la repatriación de una colección importante tanto simbólicamente, como también histórica y científicamente para la historia de la región andina.

De hecho, la colección del Museo Machu Picchu de la Casa Concha es una suerte de corte temporal de la arqueología de Machu Picchu, pues se trata de la totalidad de los artefactos y materiales encontrados por Hiram Bingham en Machu Picchu entre julio y noviembre de 
1912, tomando en cuenta la tecnología existente entonces, y las limitaciones del mismo Bingham como arqueólogo.

Quizás lo más interesante acerca de los materiales expuestos en la Casa Concha sea el hecho que no se trata de objetos fabricados como adornos suntuarios. Más bien son, en su mayoría, objetos utilitarios de cerámica, que fueron usados por la gente residente en la ciudadela de Machu Picchu, hacia los inicios del siglo XVI, para la preparación de chicha (fotografía $\mathrm{N}^{\circ} 10$ ), el tostado del maíz (fotografia $\mathrm{N}^{\circ} 11$ ) el consumo de alimentos, (fotografia $\mathrm{N}^{\circ} 12$ ) etc. Se debe asumir que esos objetos, en su mayoría encontrados en entierros por los trabajadores de Bingham, fueron utilizados diariamente por la población de cuidantes del sitio, quienes vivian todo el año en Machu Picchu.

Además de las piezas de cerámica, también se puede observar otros objetos de uso diario como son tumis (fotografia $\mathrm{N}^{\circ} 13$ ), y tupus (fotografia $\mathrm{N}^{\circ}$ 14), incluyendo tupus funerarios, cuentas, dados, instrumentos de música (fotografía $\mathrm{N}^{\circ}$ 15), herramientas para tejer (fotografia $\mathrm{N}^{\circ} 16$ ) etc. Unos objetos líticos trabajados en forma de caja, recalcan la importancia de la piedra en el mundo de los incas y su valor tanto utilitario como estético (fotografia $\mathrm{N}^{\circ} 17$ ).

Pcro otros objetos también de uso ritual, designados para ofrendas, nos invitan a una reflexión sobre interrogantes que han sido objeto de debate entre investigadores. Refiero aquí a objetos no incas, claramente norteños, o sea Chimú o Chimú-incas. Uno de ellos es una botella antropomórfica, cuyo color negro manifiesta su origen Chimú, pero cuyo labio plano parece indicar una influencia inca. Otro es un tumi, de fábrica claramente no-inca, y decorado con un motivo que parece ser un pescador practicando su oficio en el mar del norte (fotografia $\left.\mathrm{N}^{\circ} 18\right)$. Otro ejemplo es la paccha en forma de mano agarrando un q'ero, preciosa muestra de alfarería norteña, con una clara juntura que señala el uso de molde (fotografía $\mathrm{N}^{\circ} 19$ ).

La presencia de esas piezas de ofrenda venidas de partes del territorio andino cuya adición al imperio se hizo en una fase tardía de la expansión, nos lleva a repensar la ocupación y la función de Machu Picchu. De hecho, la idea de la llacta imperial de Machu Picchu, construida por un solo inca, para su uso exclusivo, y de su panaca después de su reino, parecería entrar en contradicción con esa presencia de objetos provenientes de tierras ajenas al territorio controlado por el mismo Pachacútec durante su reinado. En realidad, si bien la evidencia histórica y arqueológica soporta la construcción de Machu Picchu con mano de obra mayormente cuzqueña, la presencia de cerámicas norteñas excavadas en la ciudadela, indica que, mucho después de Pachacutec, Machu Picchu mantuvo un papel importante en la región, o bien a nivel ritual o bien a nivel comercial.

Por otro lado, otros objetos en la colección de la Casa Concha también permiten ampliar lo que se sabe de la ocupación de Machu Picchu. Se trata de unos cántaros (raki) incas encontrados en la ciudadela en la excavación de 1912. Esos aríbalos, usados en la producción de chicha, se encuentran rotos, faltando el labio abocinado y parte del cuello. Sin embargo, se puede notar que la parte de la fractura del cuello ha sido limada para permitir una reutilización posterior. Además se evidencia el uso de parches de plomo, un material que no conocían los incas (fotografía 10 , fotografía 20). Esos índices nos permiten sugerir que hubo una ocupación parcial de Machu Picchu en los tiempos coloniales y republicanos. Con esta evidencia, podemos refutar definitivamente la especulación de un abandono extendido del sitio hasta la época moderna.

No cabe duda que los objetos de la colección del museo Machu Picchu de la Casa Concha, destacan por su valor estético y artístico. Pero más allá de eso, sirven para mejor entender la historia de los incas y de Machu Picchu. En particular, evidencian una mayor extensión de la influencia de Machu Picchu, y su irradiación en el tiempo y el espacio, mucho más importante de lo que se había pensado anteriormente. 
$=100 \mathrm{ANNOS}$
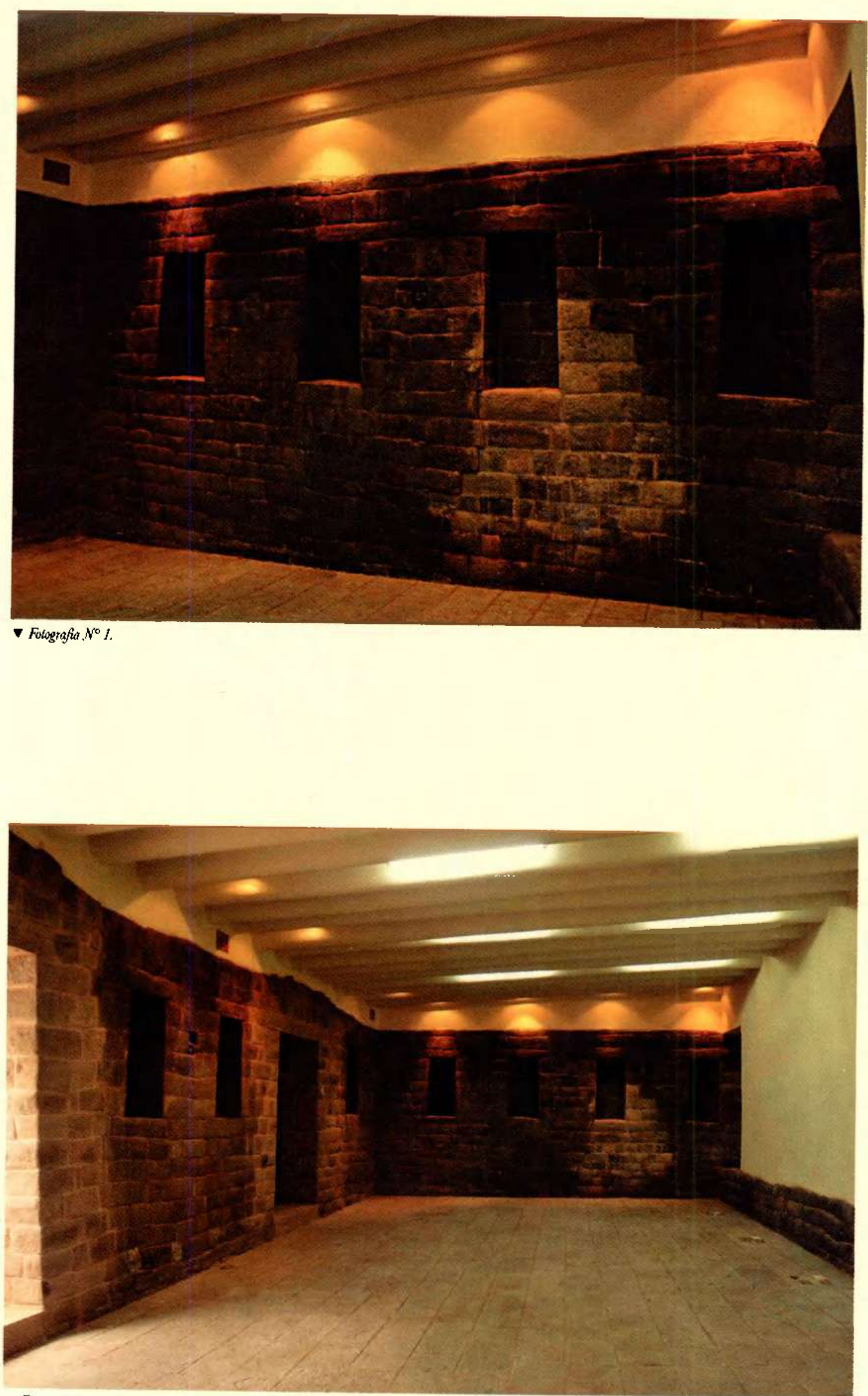

Totografia $N^{0} 2$ 


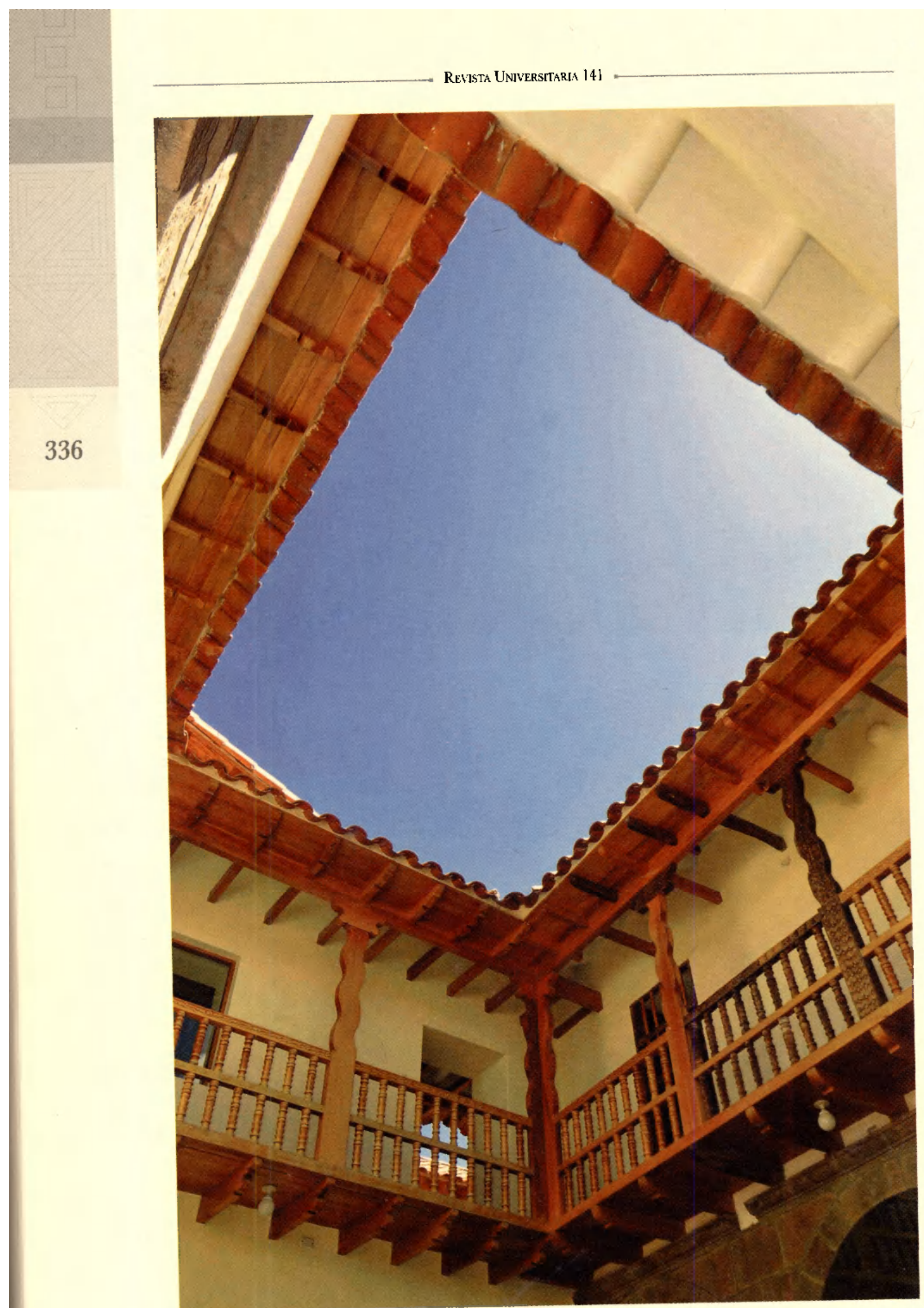

- Fotografia $\lambda^{\circ} 3$. 


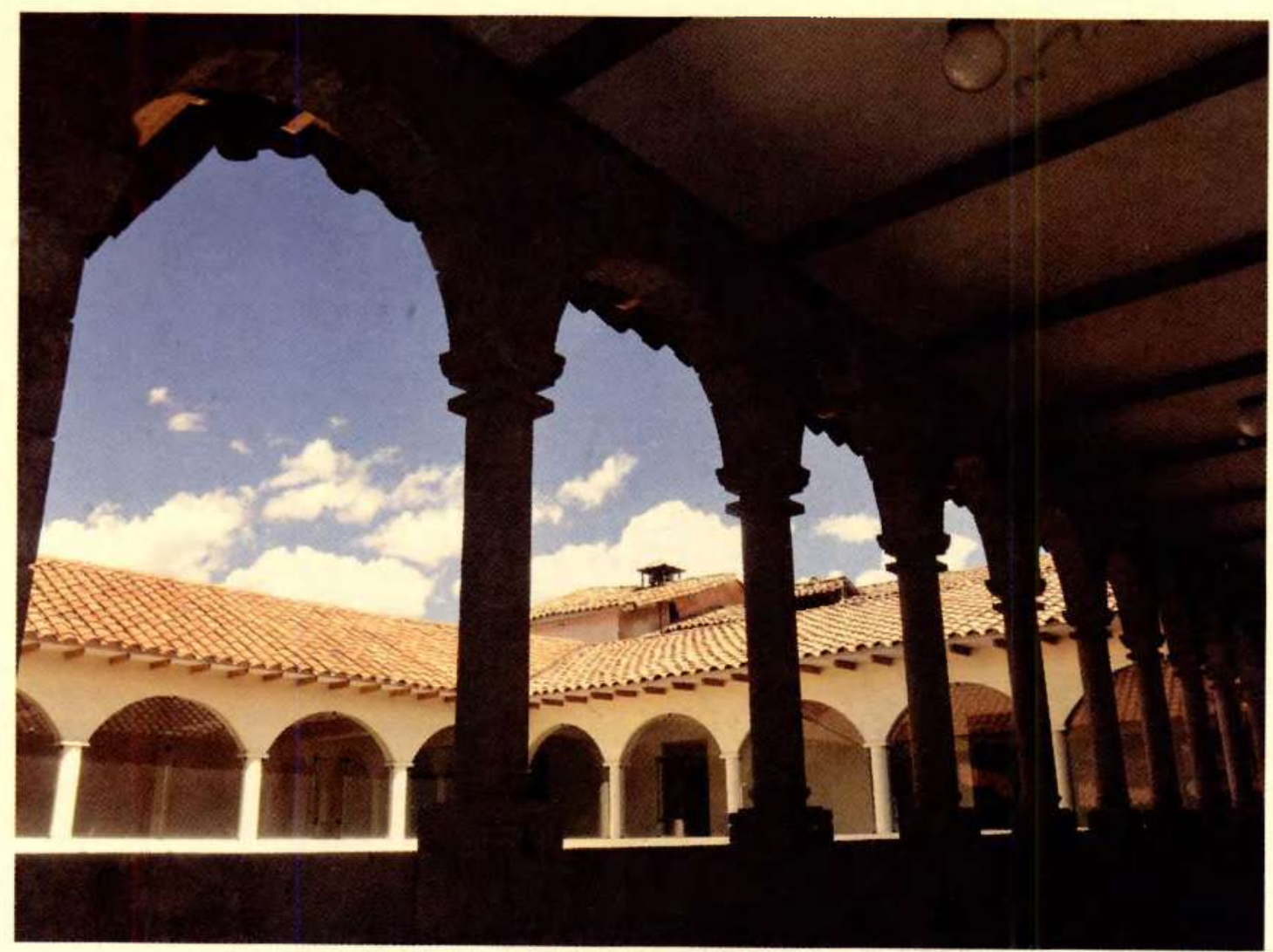

- Fotggrafin $N^{\circ} 4$.

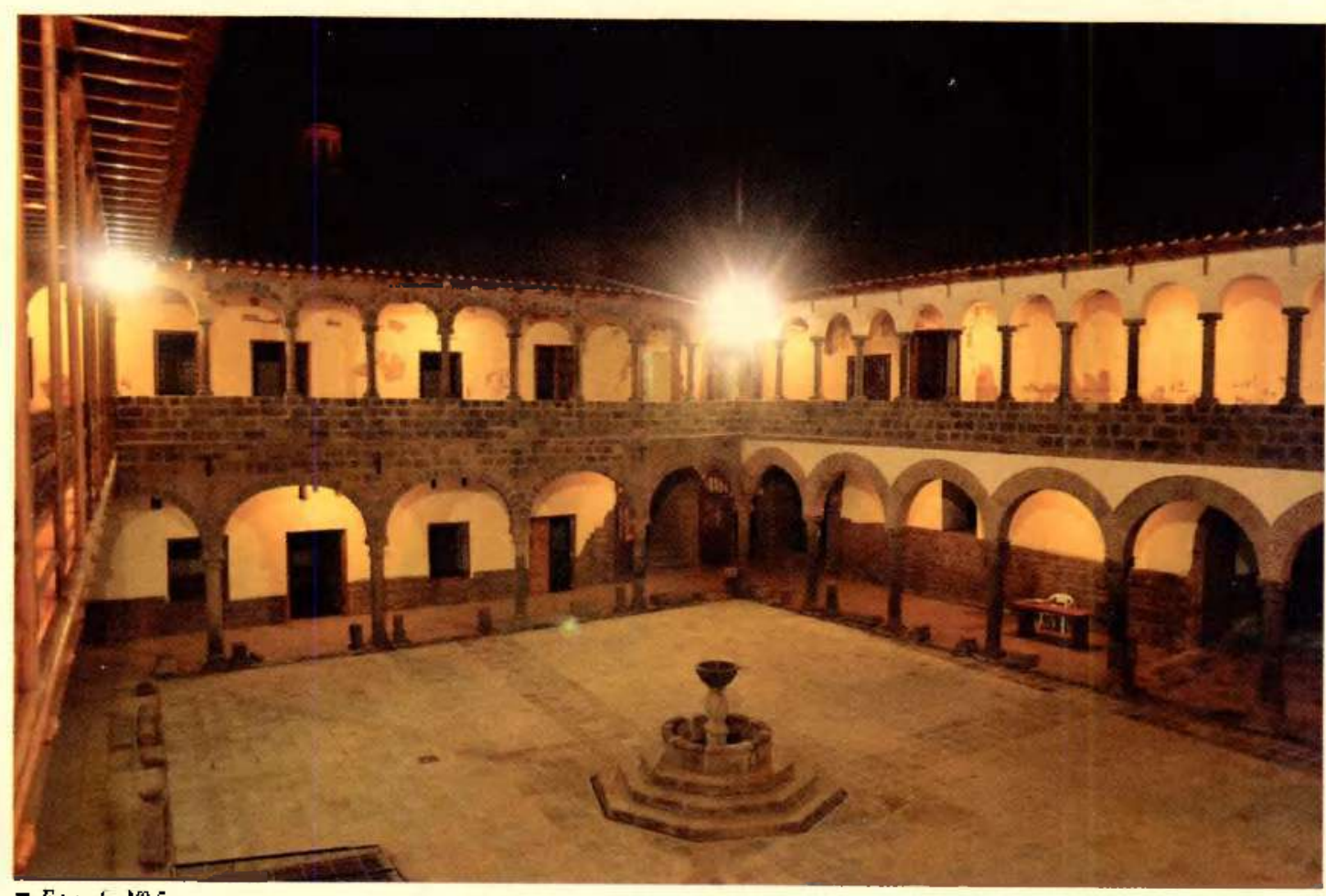




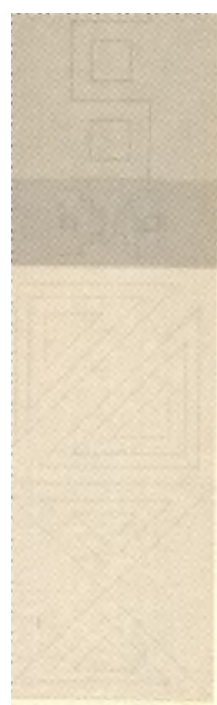

338

ReTikta UnJuersitarla 14]

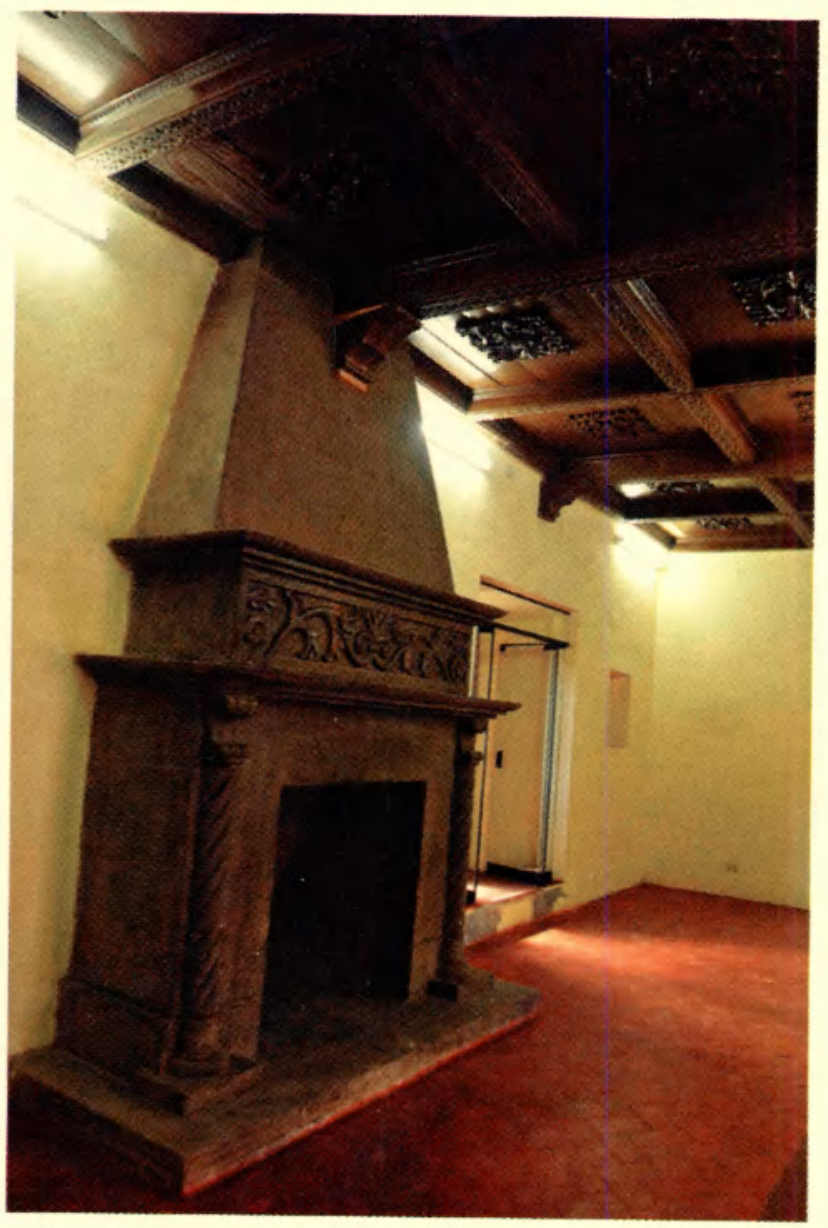

Fotografia No 6

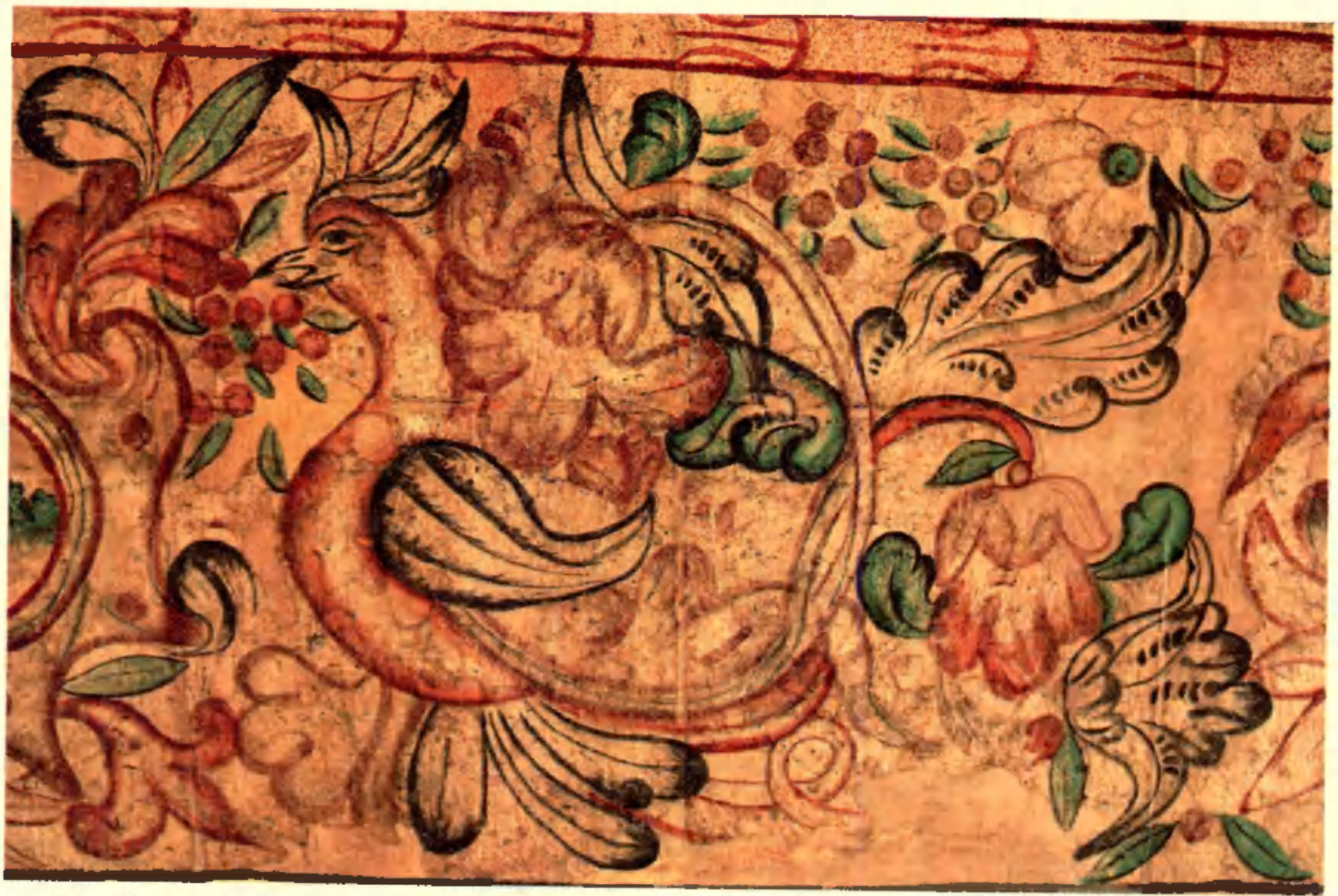

- Fotgrafia $\mathrm{V}^{7} 7$ 

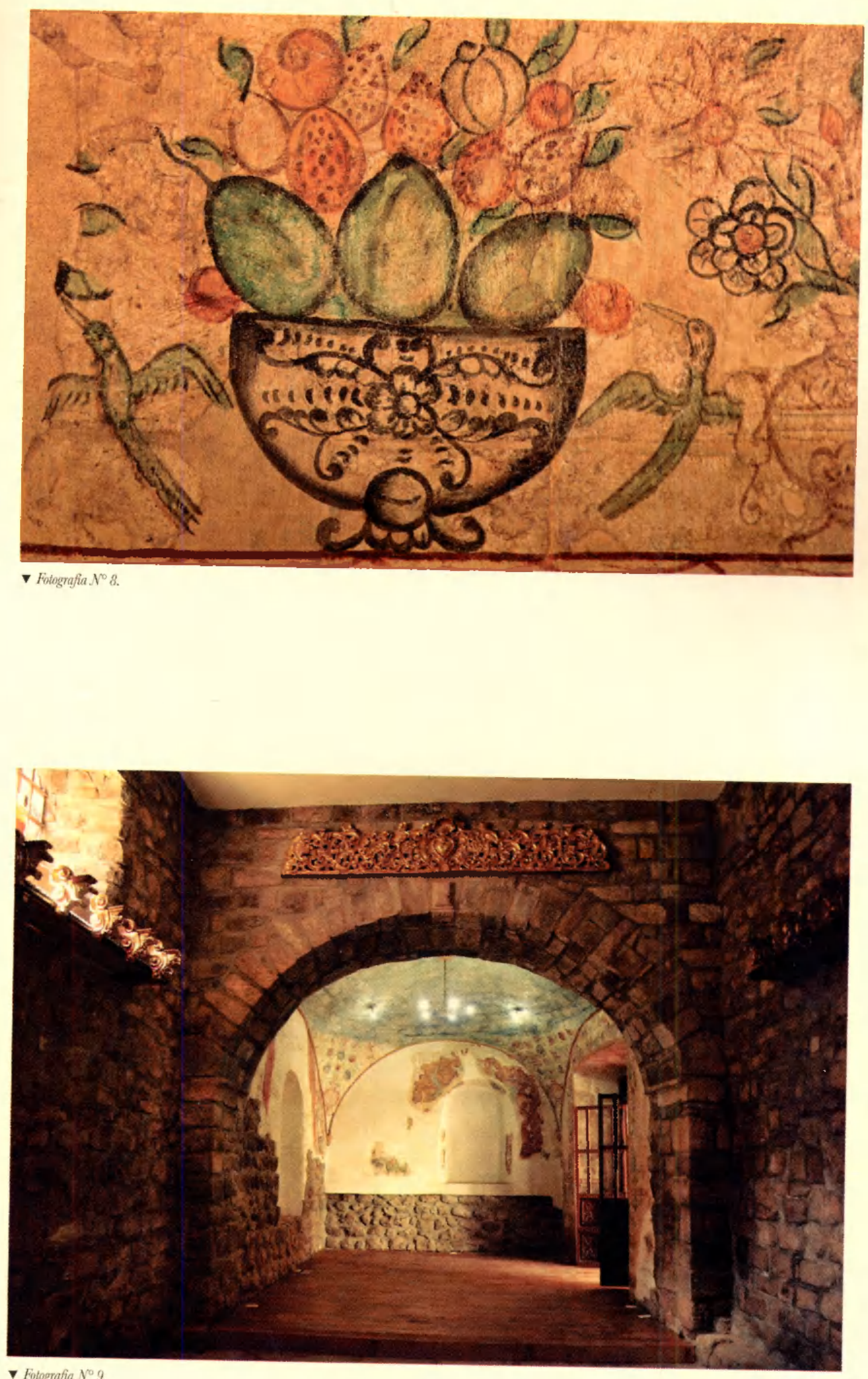

V Fotografia $N^{\circ} 9$. 


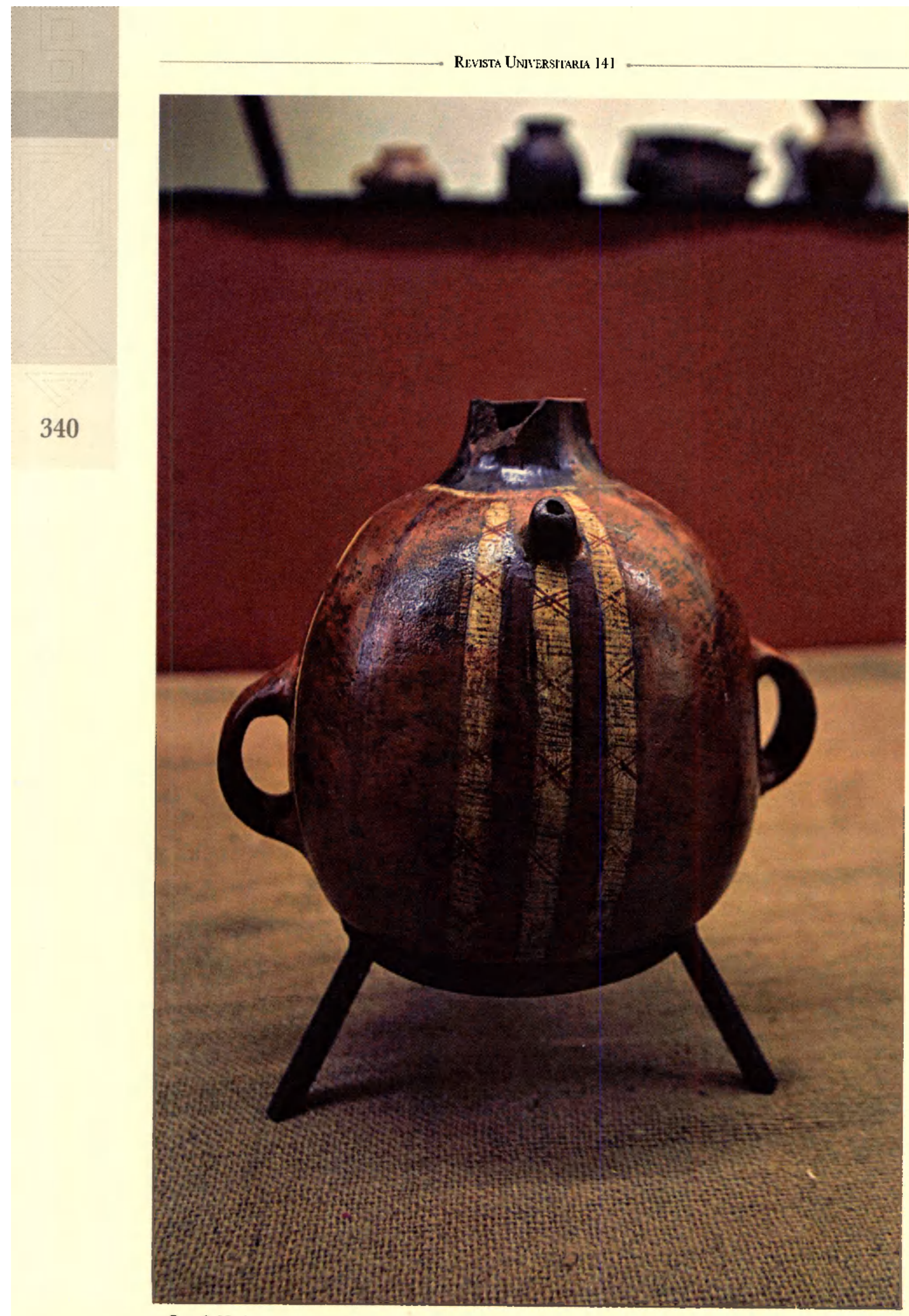

- Fotegrafia $N^{\circ} 10$ 


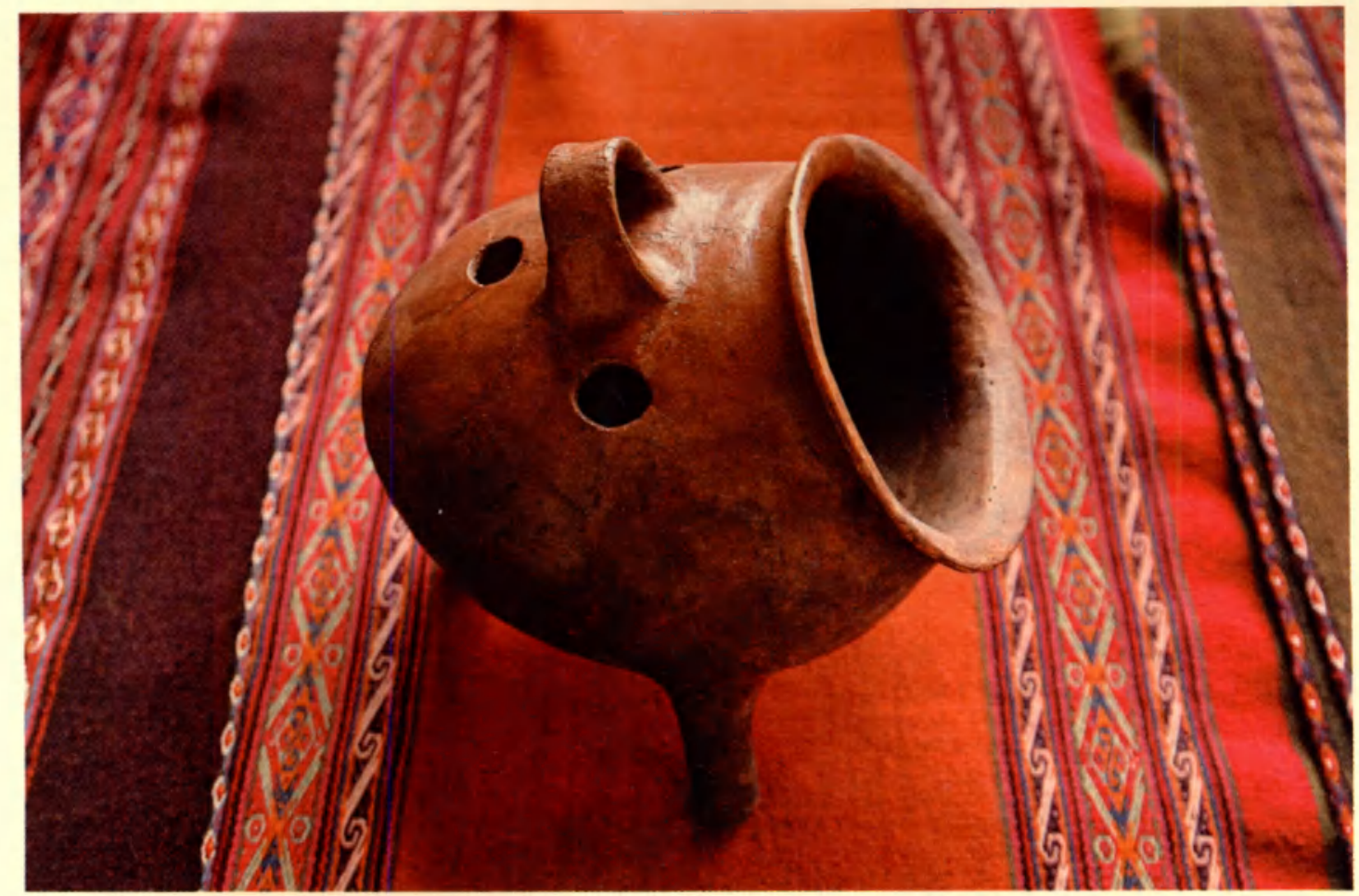

- Fotografia.Mo $\mathrm{H}$.

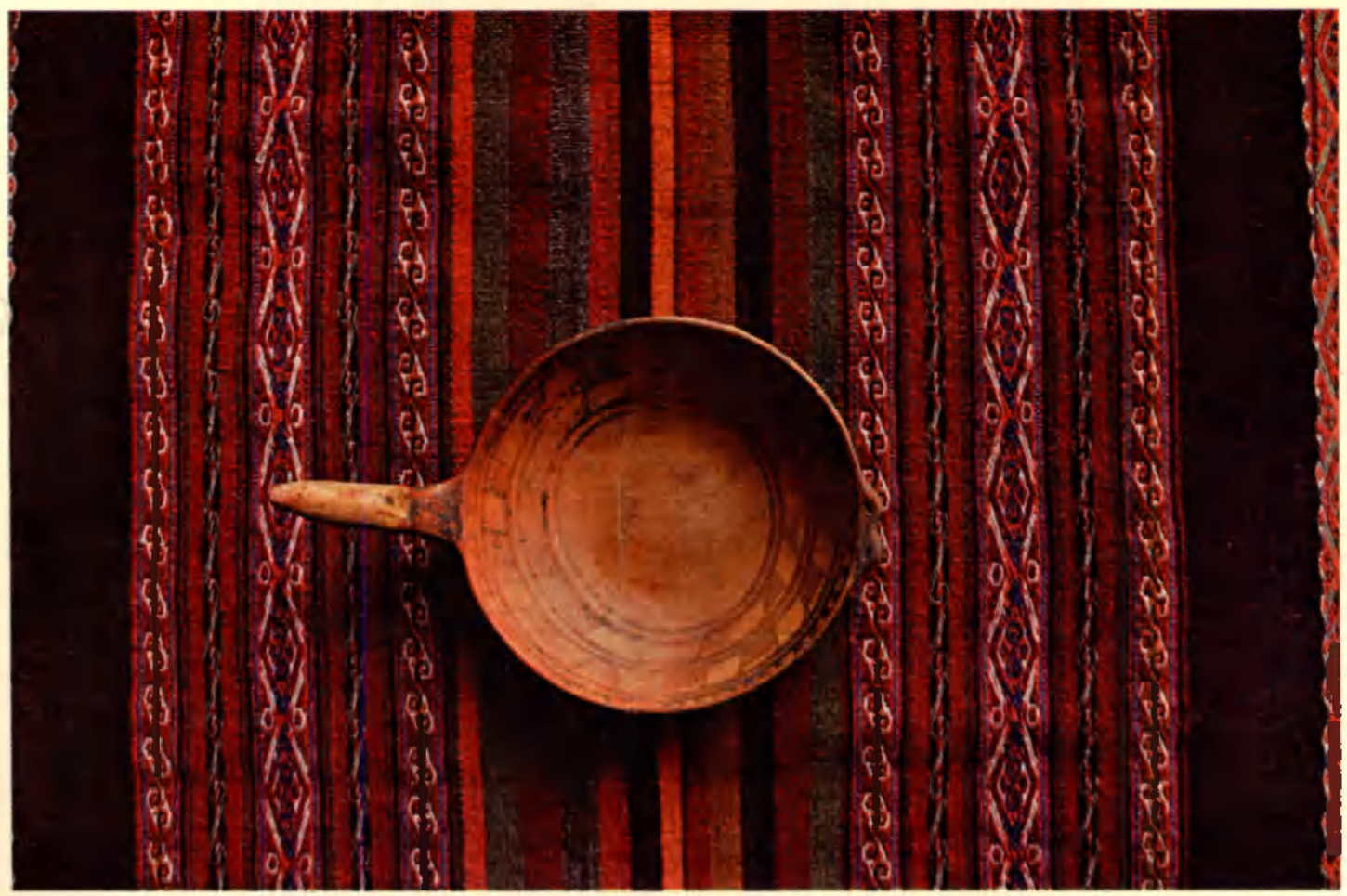

- Folografia $x^{\circ} / 2$. 


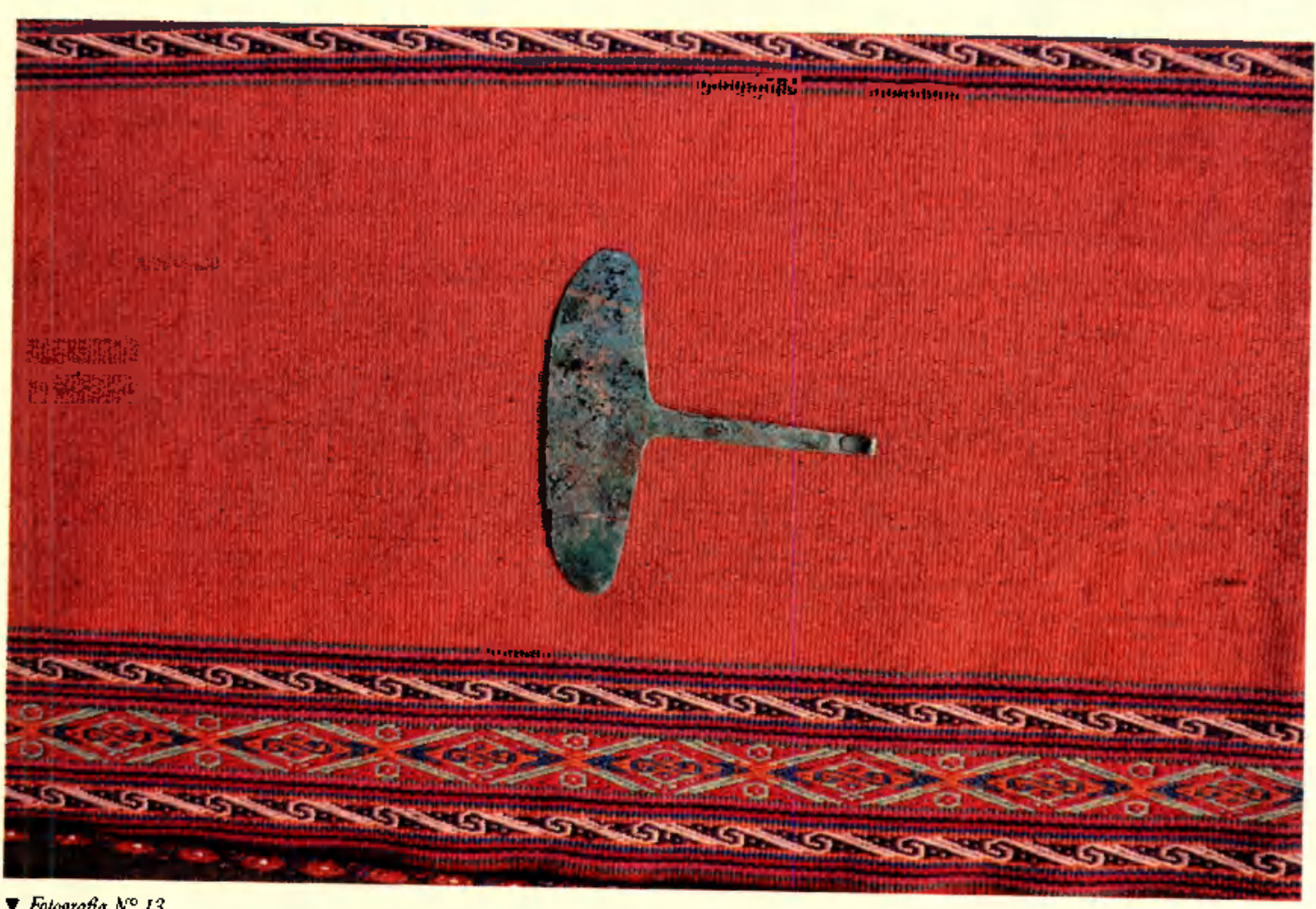

342

Totografia $N^{\circ} 13$

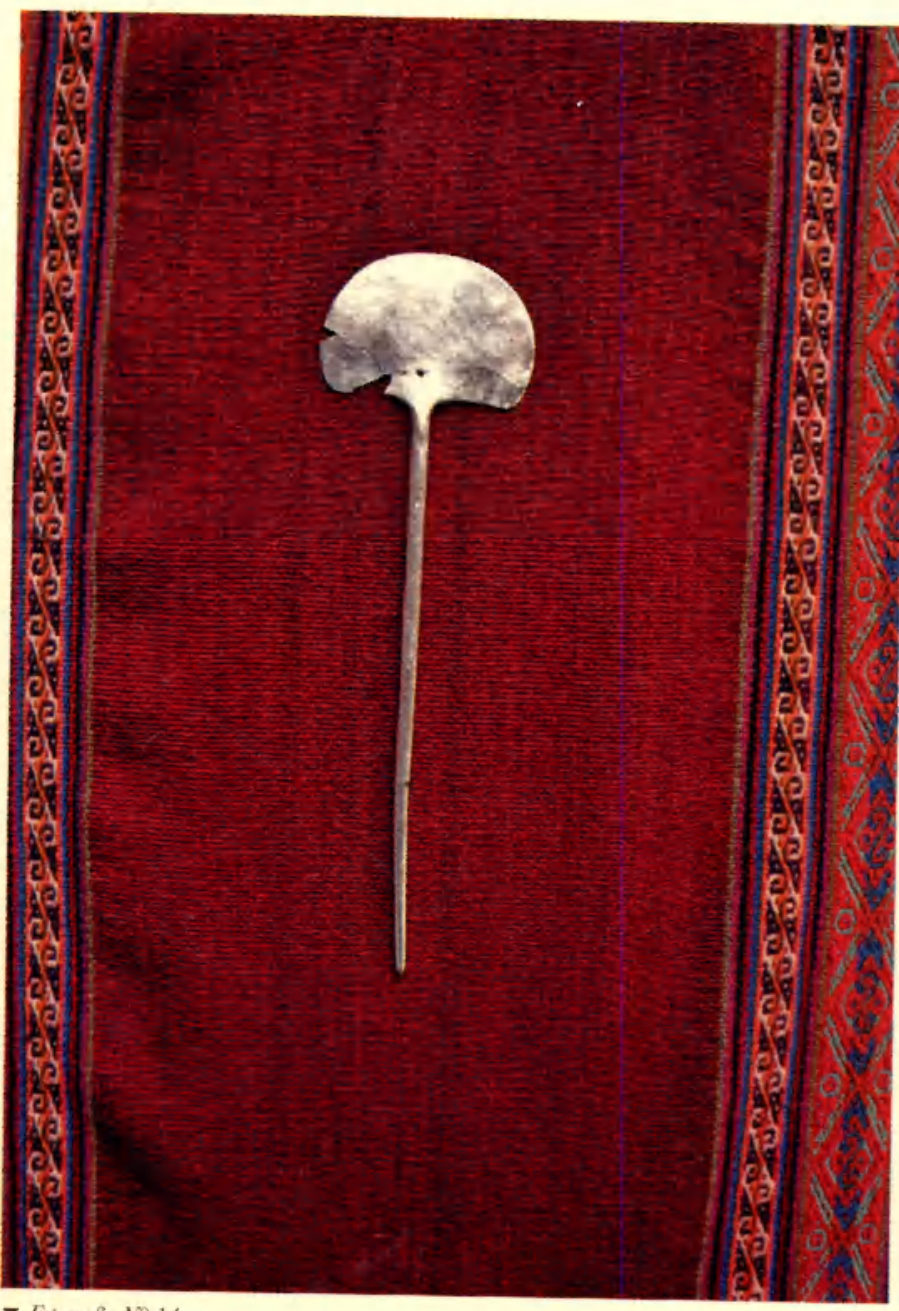

v Fotografia $N^{0} 14$. 

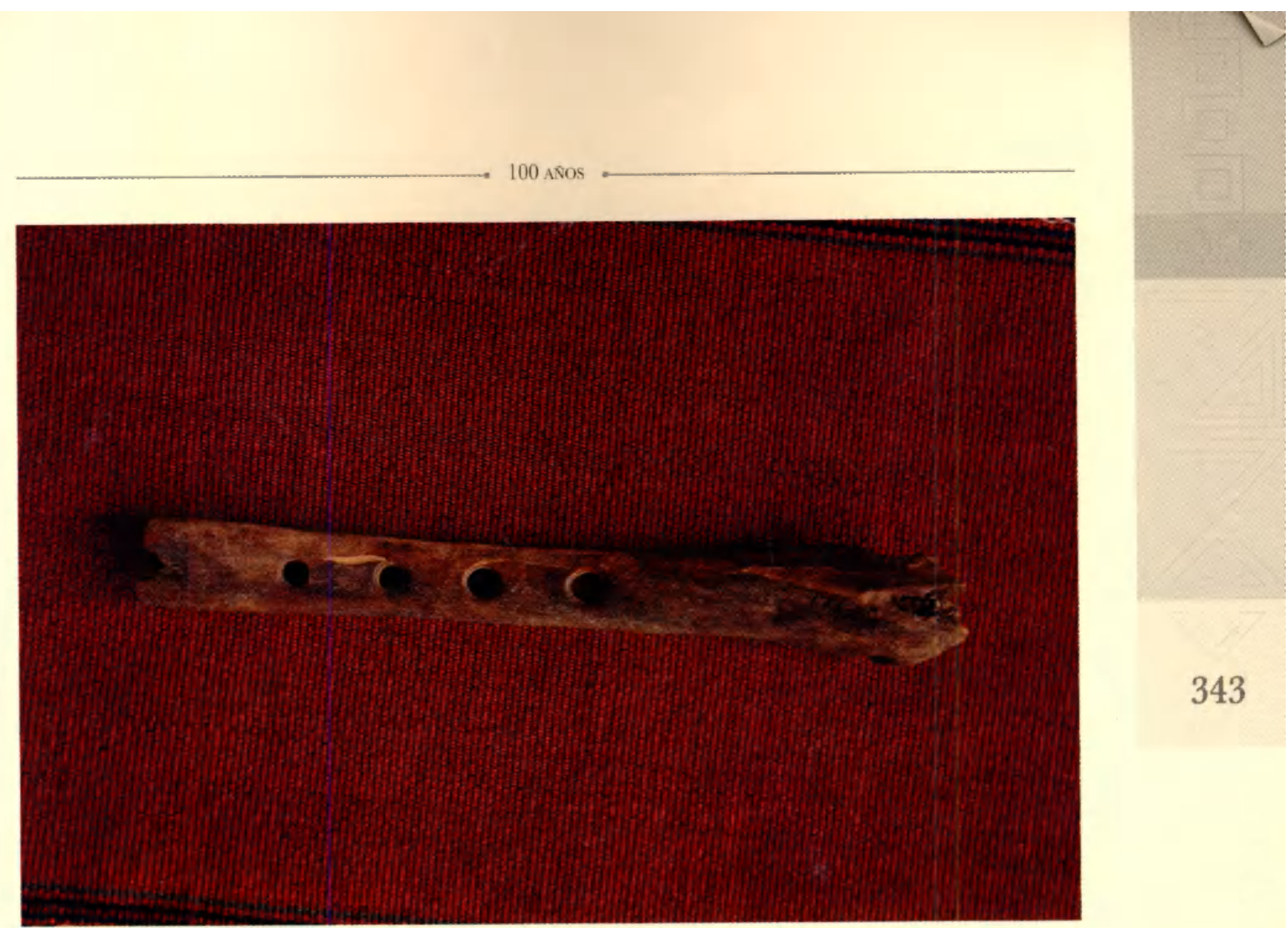

จ Fotografia $N^{0} 15$

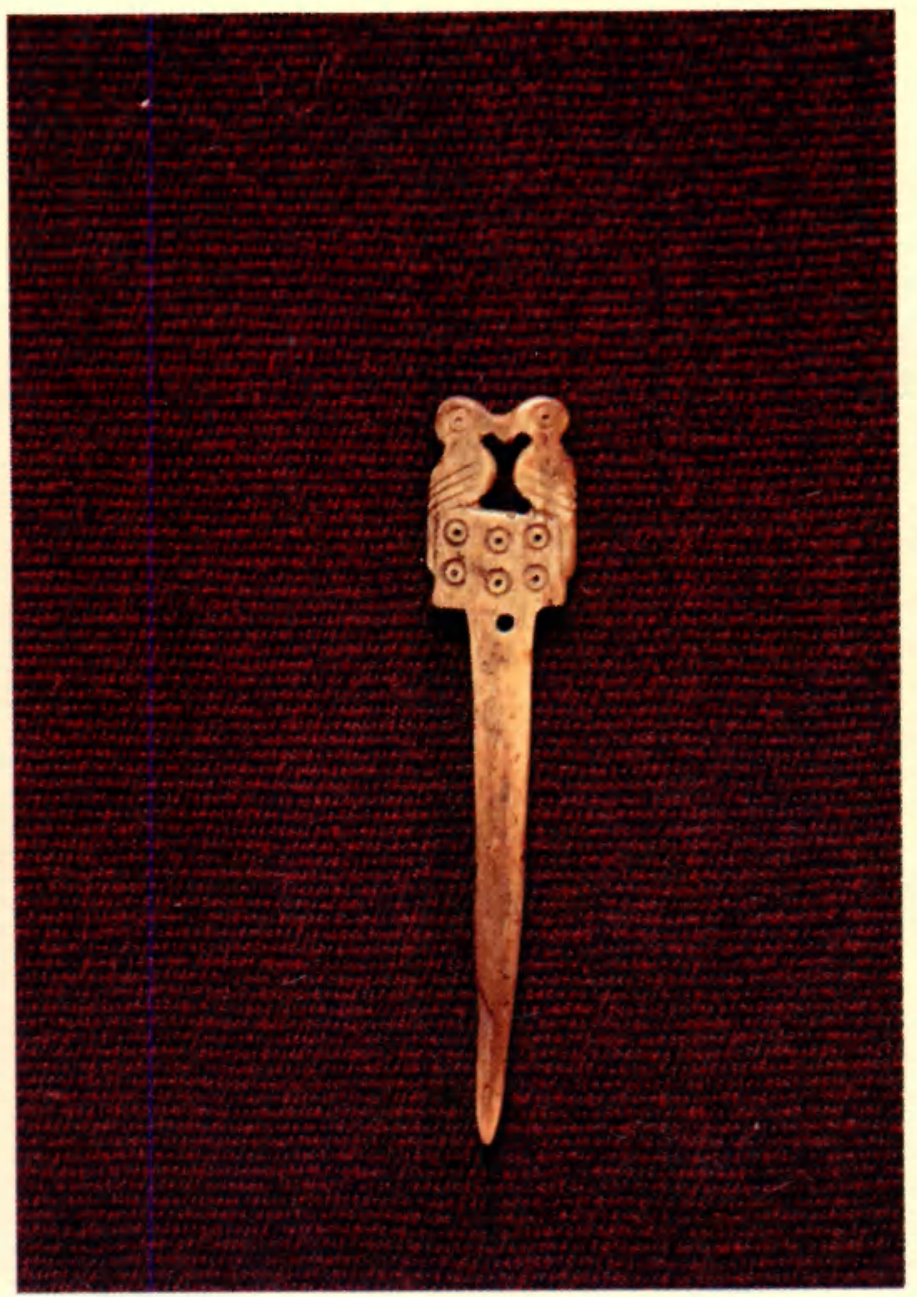

- Fotografa $N^{\circ} / 6$ 
REtista Universithala 141

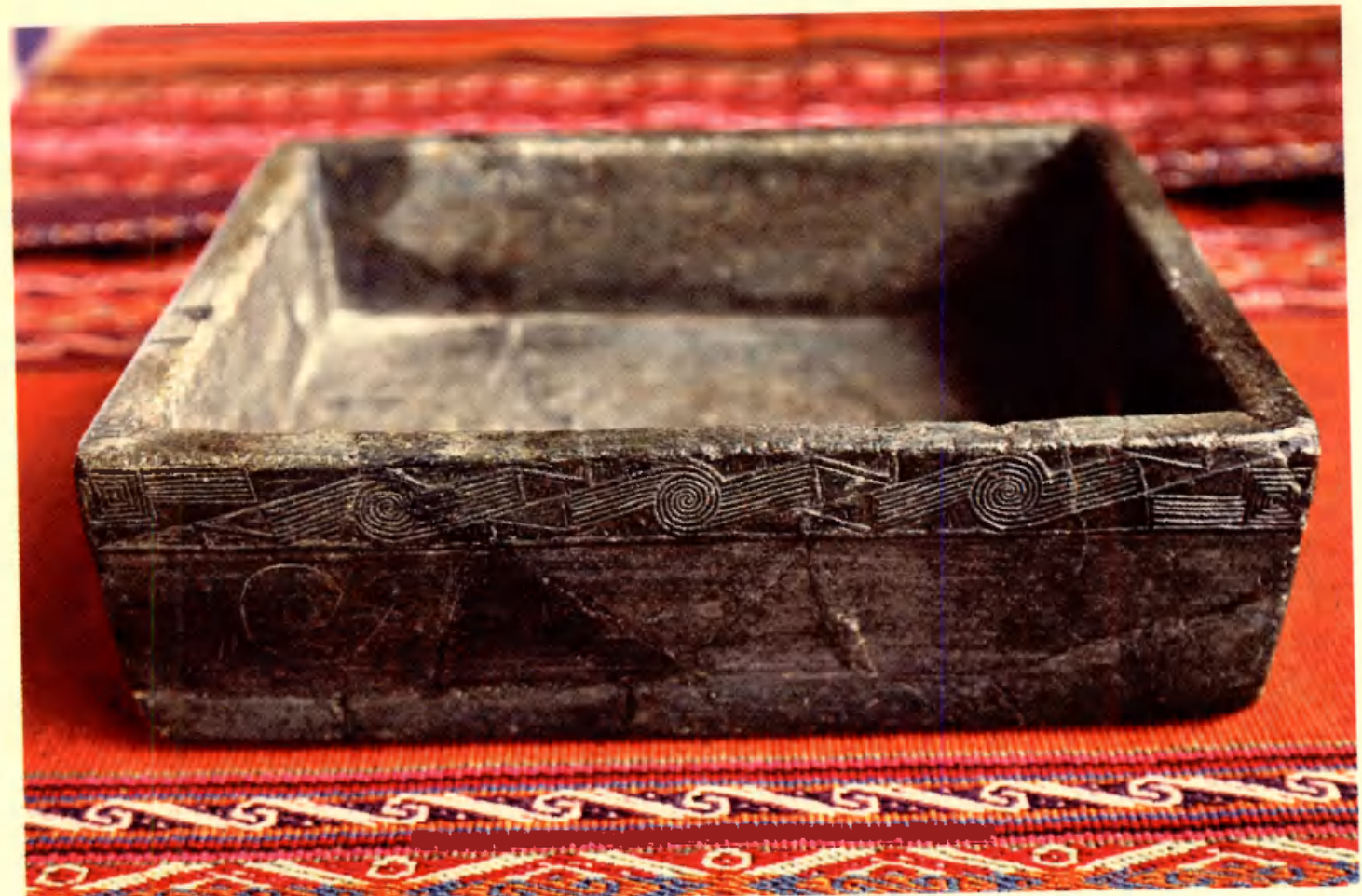

Totografia $N^{0} / 7$

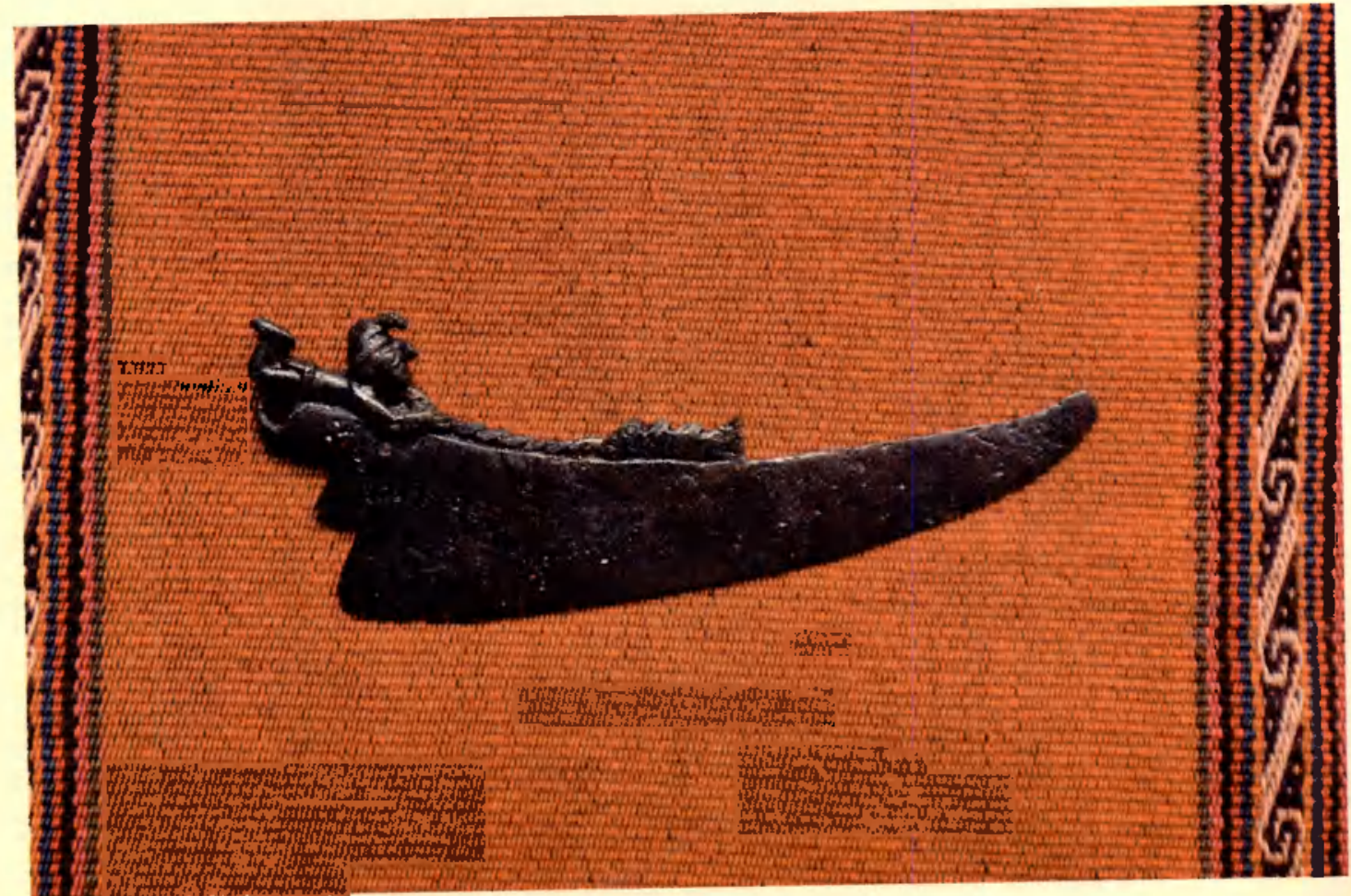

- Fotugrafia $1^{\circ} 18$ 


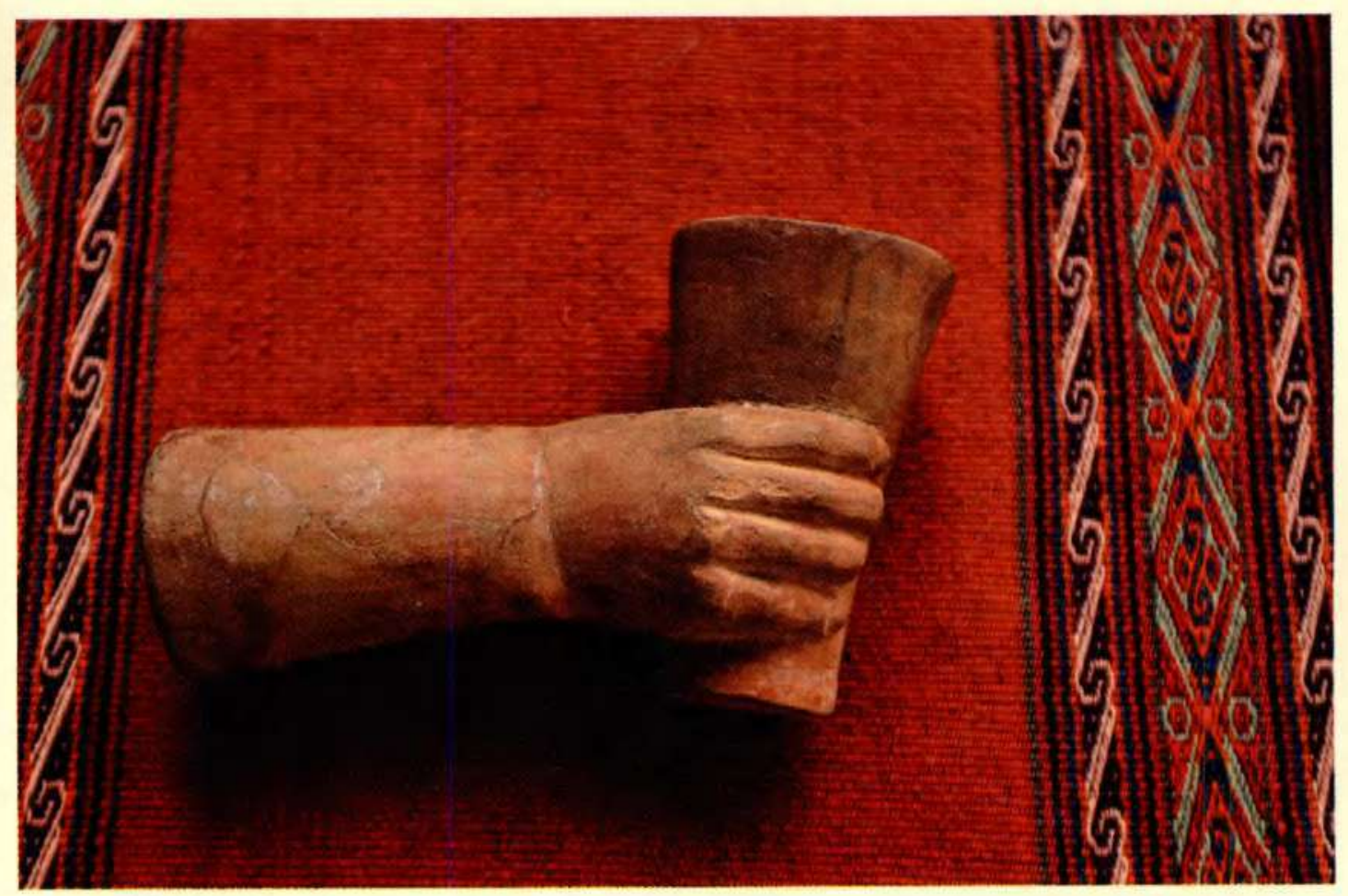

- Fotografia N $N^{\circ} 19$

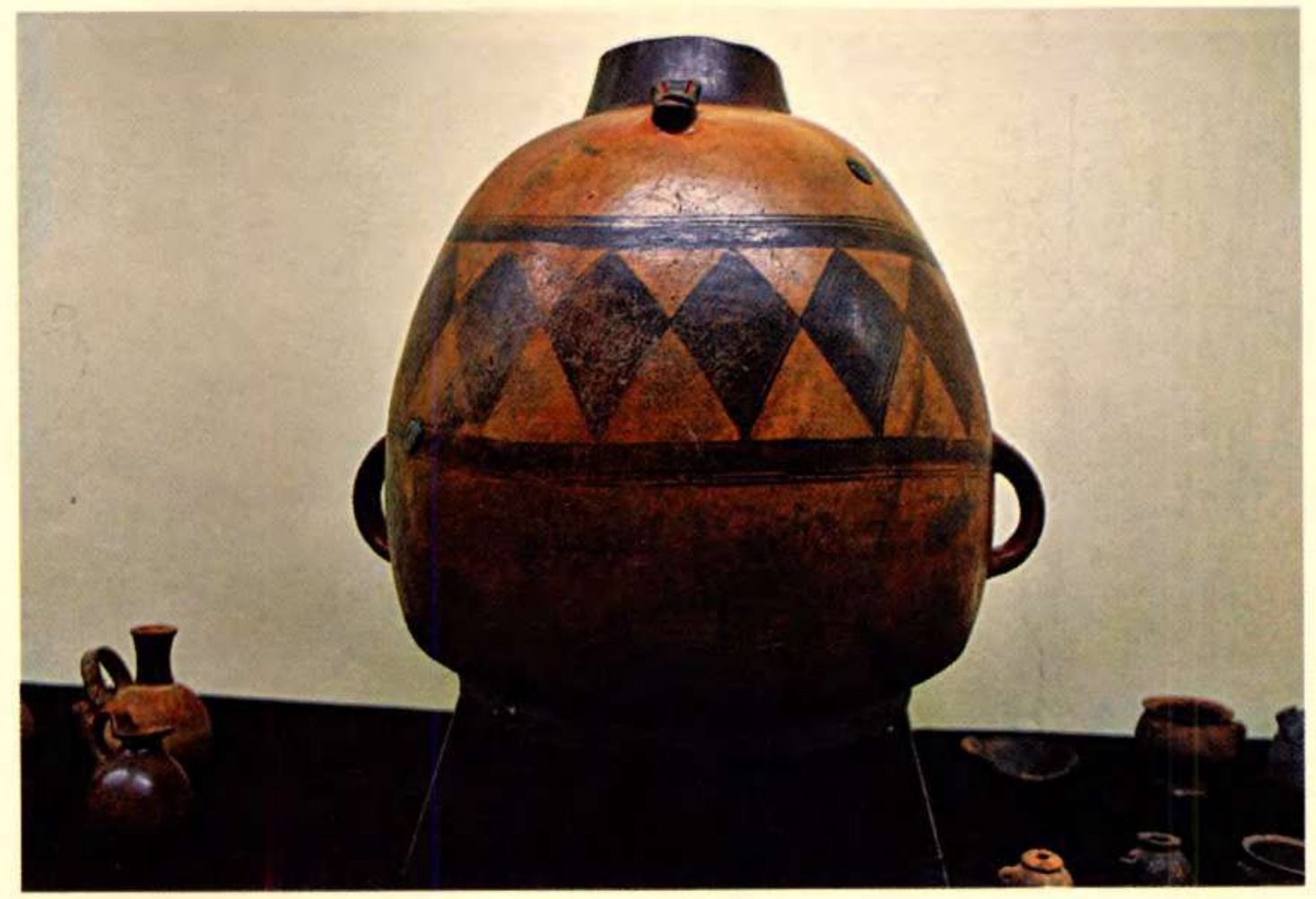

- Fotografa $N^{\circ} 20$. 


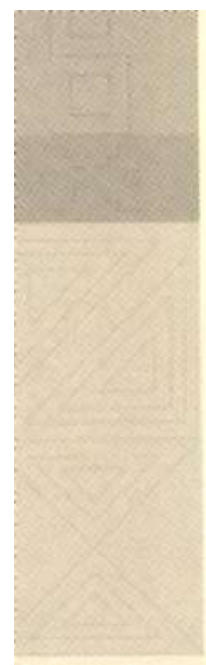

Revista Univers[taria 14]

346

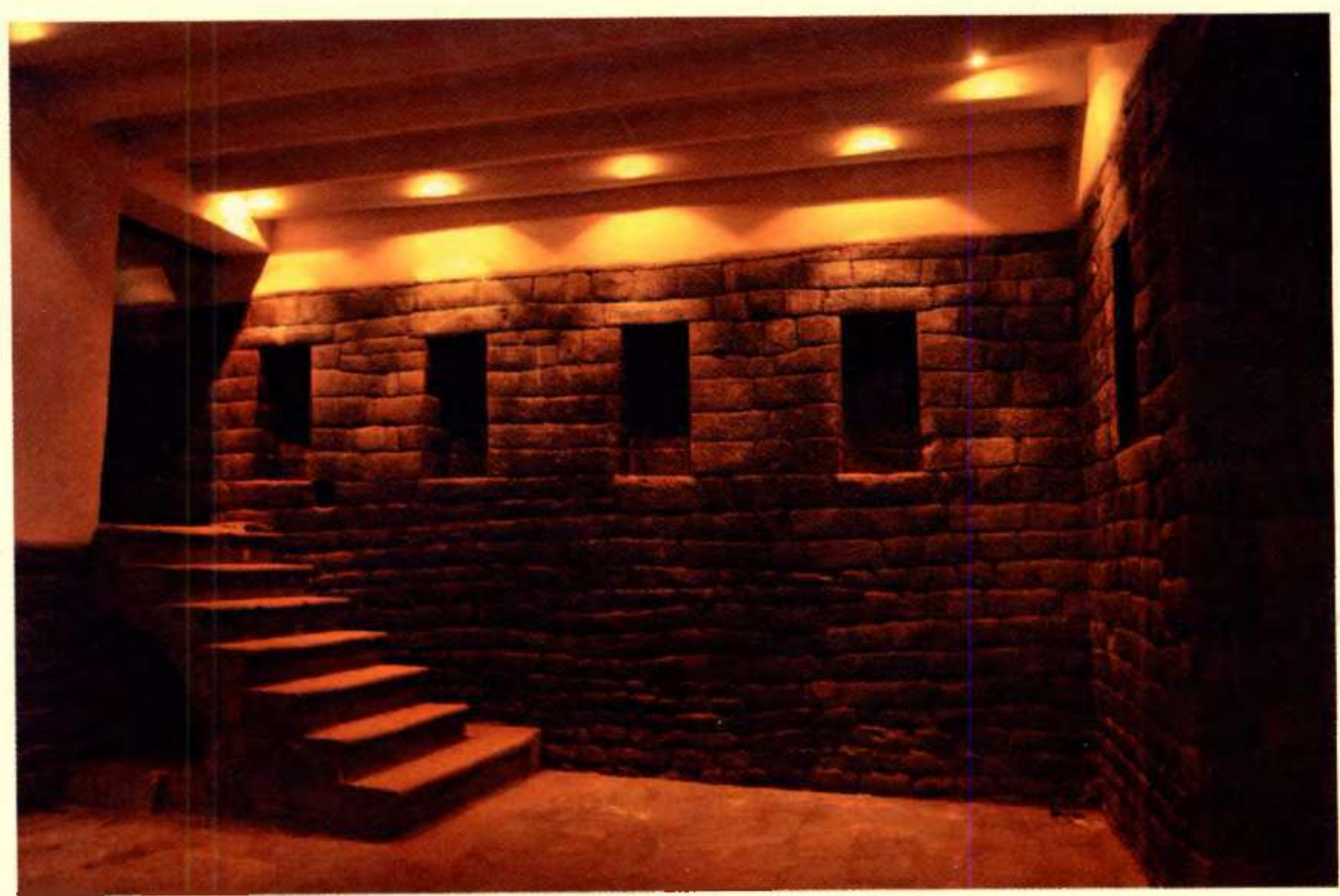

- Miseo de la Casa Concha, muro de lo que fue el palacio de Tupar Inca Yupangui.

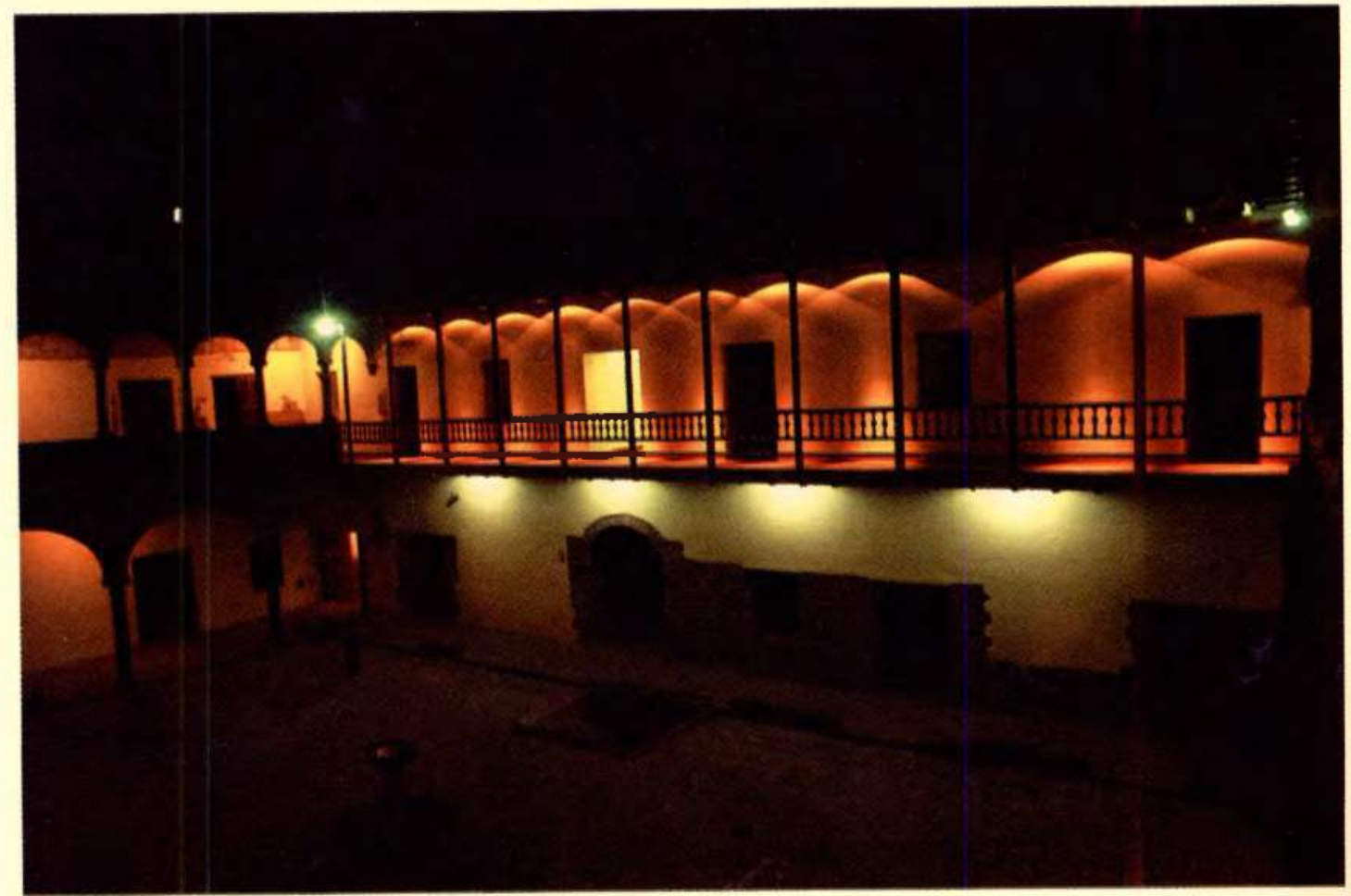

v Museo de la Casa Concha, vista nochuma del patio principal. 


\section{Autores}

\section{ACURIO MENDOZA, María Lourdes}

Biologa, Universidad Nacional de San Antonio Abad del Cusco Profesora Cesante de la Facultad de Ciencias Biológicas

\section{ACURIO SAAVEDRA, Elena Emperatriz}

Biologa, Universidad Nacional de San Antonio Abad del Cusco Investigadora en World Vision

elenacusa@yahoo.es

\section{ACURIO SAAVEDRA, Jorge}

M. Sc. Mejoramiento Genético de Plantas

Universidad Nacional Agraria La Molina

Profesor Asociado, Facultad de Biología

jorge.acurio@unsaac.edu.pe

\section{ALAGóN HUALLPA, Gilbert}

Candidato a Doctor en Ciencia y Tecnología de la Producción Animal,

Universidad Politécnica de Valencia. España.

Profesor Principal, Facultad de Agronomía y Zootecnia galagon15@gmail.com

\section{ARAGÓN ROMERO, José Israel}

Biólogo. Universidad Nacional de San Antonio Abad del Cusco

Especialista en Conservación de la Biodiversidad, Gobierno Regional Cusco

israelaragon@hotmail.com

\section{ARÉSTEGUI PEZÚA, Alfonso}

Doctor en Medio Ambiente y Desarrollo Sostenible, Universidad Nacional Federico Villarreal

Profesor Principal, Facultad de Biología

aarestegui@yahoo.es

\section{CÁCERES CHALCO, Efraín}

Magíster en Antropología, PUC

Profesor Principal, Facultad de Comunicación Social e Idiomas

caceres@hotmail.com

\section{CASTAÑEDA SÁNCHEZ, Miguel Grimaldo}

Maestro en Derecho, Mención en Giencias Penales, Universidad San Martín de Porres

Profesor Principal, la Facultad de Derecho micasan1@hotmail.com

\section{COSIO CUENTAS, Pompeyo}

Doctor en Medio Ambiente y Desarrollo Sostenible, Universidad Federico Villarreal

Vicerrector Académico

teocosio@gmail.com

\section{DÁVILA ROJAS, Carlos Arturo}

Doctor en Ciencias, Mención en Economía y Gestión, Universidad Nacional de San Agustín de Arequipa

Profesor Principal, Facultad de Economía cadavila59@homail.com

\section{DECOSTER, Jean-Jacques}

Doctor en Antropología, Cornell University.

Director del Musco Machupicchu de la Casa Concha jeanjacquesdecoster@gmail.com

\section{DÍAZ OBLITAS, Jorge José}

Maestro en Ciencias, Universidad Nacional de Ingeniería, Mención en Arquitectura

Profesor Principal, Facultad de Arquitectura y Artes Plásticas jjdio8@hotmail.es

\section{EUFRACIO, Pedro}

Ingeniero Pesquero, Universidad Nacional Federico Villarreal pseufracio@viabcp.com

\section{FARFÁN VARGAS, Jim}

Biólogo, Universidad Nacional de San Antonio Abad del Cusco. Gerencia de Desarrollo del Gobierno Regional del Cusco

\section{FLORES OCHOA, Jorge}

Doctor en Antropología, Universidad Nacional de San Antonio Abad del Cusco

Profesor Principal en la Facultad de Ciencias Sociales jorgeflores@peru.com

\section{GONZALES BELLIDO, Janet}

Químico, Universidad Nacional de San Antonio Abad del Cusco. Profesor, Facultad de Ciencias Químicas, Físicas y Matemáticas jfgobel@yahoo.es

\section{LEGHUGA GHAGÓN, Ana}

Químico, Universidad Nacional de San Antonio Abad del Cusco. Profesor Auxiliar, Facultad de Ciencias Químicas, Físicas y Matemáticas labquim@yahoo.com 


\section{LUIZAR OBREGÓN, Gelina}

Doctora en Química, Universidad Estadual de Campinas

Profesora Asociado, Facultad de Ciencias Químicas, Fisicas y Matemáticas

celinaluizar@gmail.com

\section{LUNA FARFÁN, Faustino}

Maestro en Derecho Constitucional, Universidad Federicó Villarreal

Candidato a Doctorado en Derecho, Universidad del País Vasco-España

Profesor Principal T.C. Facultad de Derecho y Ciencias Políticas luna_abogados@hotmail.com

\section{MADERA TUPAYACHI, Elena Emperatriz}

Biólogo, Universidad Nacional de San Antonio Abad del Cusco

Profesora Principal, Facultad de Biología
QUISPE, Elmer

Ingeniero Zootecnista, Universidad Nacional de San Antonio Abad del Cusco

elmerzinho@yahoo.com

ROSAS PARAVICINO, Enrique

Escritor

rozas7777@hotmail.com

\section{ROZAS ÁLVAREZ, Garmen Antonieta}

Arquitecta, Universidad Nacional de San Antonio Abad del Cusco

COPESCO

crozad@hotmail.com

\section{SAMANEZ PAZ, Carmen Irma}

Licenciada en Educación, Universidad Nacional de San Antonio Abad del Cusco

Profesora Principal, Facultad de Comunicación Social e Idiomas carmensamanezpaz@hotmail.com

\section{SERRANO FLORES, Alberto}

Magíster en Química, PUCP

Profesor Principal Facultad de Ciencias Químicas, Fúsicas y Matemáticas

cas22050@hotmail.com

\section{TAMAYO HERRERA, José Armando}

Miembro de Número de la Academia Nacional de la Historia jtamayoh@hotmail.com

\section{TUPAYACHI HERRERA, Alfredo}

Magíster en Ciencias, Mención Ecología y Recursos Naturales, Universidad Nacional de San Antonio Abad del Cusco

Profesor Cesante, Facultad de Ciencias Biológicas atupayachi@yahoo.com

\section{VALDIVIA RIVERA, Gustavo}

Magister, Universidad Peruana Cayetano Heredia Profesor Principal, Facultad de Ciencias Sociales valdiviariverag@gmail.com

\section{VARGAS LLOSA, Mario}

Premio Nobel de Literatura, 2010

VENERO GONZÁLES, José Luis

Doctor en Ciencias Biológicas. Universidad de Sevilla España Docente Investigador Cesante, Facultad de Ciencias Biológicas josvengon@gmail.com

\section{YABARRENA URDAY, José Eufemio}

Biólogo, Universidad Nacional de San Antonio Abad del Cusco Profesor Auxiliar TC, Facultad de Ciencias Biológicas

\section{ZAMALLOA ACURIO, Violeta Eugenia}

Magister en Ciencias, Universidad Nacional de San Antonio Abad del Cusco

Jefe de Prácticas, Facultad de Ciencias Biológicas viozaac@gmail.com 